\title{
Impacts of land-use conversion in Sumatra, Indonesia on soil nitrogen cycling, soil nutrient stocks and ecosystem dynamics
}

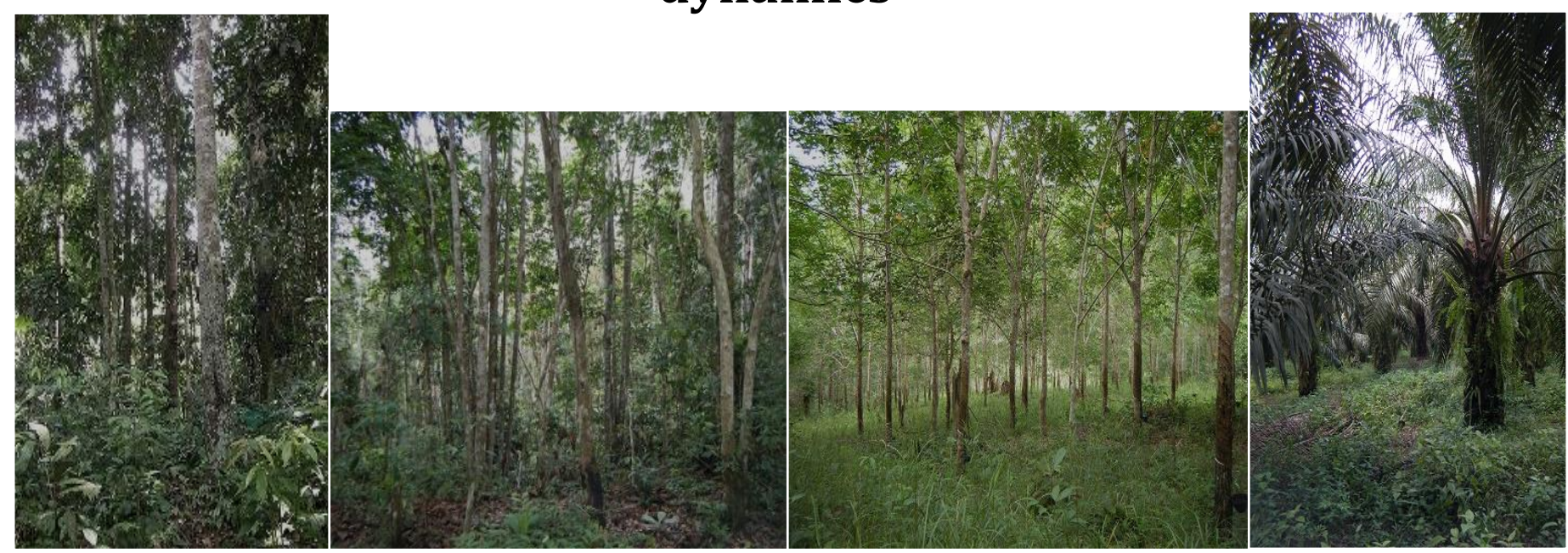

Dissertation

Zur Erlangung des akademischen Grades Doctor of Philosophy (PhD)

der Fakultät für Forstwissenschaften und Waldökologie

der Georg-August-Universität Göttingen

vorgelet von

Kara Allen

aus

Spartanburg, S.C., U.S.A.

Göttingen, July 2015 

Gutachter: Edzo Veldkamp

Gutachter: Dirk Hölscher

Thesis defense: September 28, 2015

PhD supervisors: Prof. Dr. Edzo Veldkamp and Dr. Marife D. Corre 



\section{Contents}

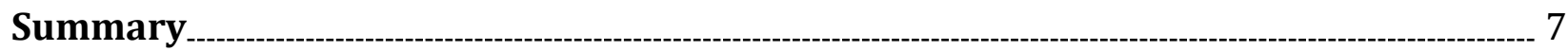

Zusammenfassung 9

Chapter 1. General Introduction. 13

1.1. Land-use change in Southeast Asia 14

1.2. Soils and land-use change 15

1.3. The internal soil nitrogen cycle 16

1.4. A call for multifunctionality 18

1.5. The EEFForTs project 19

1.6. Aims and hypotheses 20

Chapter 2. Soil nitrogen-cycling responses to conversion of lowland forests to oil palm and rubber plantations in Sumatra, Indonesia

2.1. Introduction 28

2.2. Materials and Methods

2.3. Results 37

2.4. Discussion 43

2.5. Conclusions 47

Supplementary material 53

Chapter 3. Spatial variability surpasses land-use change effects on soil biochemical properties of converted lowland landscapes in Sumatra, Indonesia

3.1. Introduction 58

3.2. Materials and Methods 61 
3.3. Results 64

3.4. Discussion 70

3.5. Conclusions 74

Chapter 4. Tropical land use imposes direct and cascading impacts on biodiversity from bacteria to birds

Supplementary material _..___ 88

Chapter 5. Synthesis 105

5.1. Soil-N cycling responses to land-use conversion _...__ 105

5.2. Spatial variability surpasses land-use change effects on soil biochemical properties 109

5.3. Tropical land use imposes direct and cascading impacts on biodiversity 111

Supplementary material 117

Acknowledgments 119

Curriculum Vitae 121 


\section{Summary}

Over the last two decades, deforestation rates in Sumatra, Indonesia have rapidly increased resulting in the conversion of large tracts of lowland forest into monoculture plantations of oil palm (Elaeis guineensis) and rubber (Hevea brasiliensis). Land-use conversion to agricultural systems has been found to decrease soil nutrient stocks and soil nutrient cycling rates overtime, which can lead to a dependence on fertilization that only temporarily improves soil nutrient availability. Furthermore, conversion of forest to crop monocultures threatens the high levels of biodiversity present in tropical forested systems, which subsequently influences ecosystem functioning. The focus of this thesis was to determine the impacts of land-use conversion on soil nutrient status and ecosystem dynamics, as well as provide an understanding of the mechanisms driving these changes. All three studies were a part of a large interdisciplinary research project examining the environmental and social effects of tropical land-use change. Sampling for each study took place in Jambi Province, Sumatra, Indonesia-an area that was once heavily forested, but has experienced high forest conversion. Two soil landscapes, defined by their dominant soil texture and type, were selected to represent the region: loam and clay Acrisol soils. In each soil landscape, four land-use systems were examined: lowland rainforest and rubber interspersed in naturally regenerating forest (referred here as "jungle rubber") and monoculture plantations of rubber (7-17 years old) and oil palm (9-16 years old).

The aim of the first study was to assess changes in soil nitrogen (N) cycling rates with conversion of forest to oil palm and rubber plantations. Gross soil-N cycling rates were measured using the ${ }^{15} \mathrm{~N}$ pool dilution technique with in-situ incubation of soil cores. In the loam Acrisol soil, where fertility was low, microbial biomass, gross $\mathrm{N}$ mineralization and ammonium $\left(\mathrm{NH}_{4}{ }^{+}\right)$ immobilization were also low and no significant changes were detected with land-use conversion. The clay Acrisol soil, which had higher initial fertility based on the reference land uses had larger microbial biomass and $\mathrm{NH}_{4}{ }^{+}$transformation rates compared to the loam Acrisol soil. Conversion of forest and jungle rubber to rubber and oil palm in the clay Acrisol soil decreased soil fertility subsequently reducing microbial biomass and decreasing $\mathrm{NH}_{4}{ }^{+}$transformation rates. Our findings suggest that the larger the initial soil fertility and N availability, the larger the reductions upon landuse conversion.

The aim of the second study was to assess changes in soil biochemical characteristics and soil nutrient stocks down to $2 \mathrm{~m}$ depth with land-use change, and to determine the proportions of overall variance of soil biochemical characteristics that were accounted by the spatial components 
within our nested experimental design. Clay content influenced soil fertility and the higher nutrient stocks were found in the clay Acrisol reference land uses. Management practices in the converted land uses exerted the strongest influences on soil $\mathrm{pH}$, base saturation, extractable phosphorus and exchangeable sodium. The majority of the soil biochemical characteristics and nutrient stocks did not exhibit significant effects of land-use change. Based on variance components analysis on the nested spatial structure of our experimental design, the overall variance on many of the soil biochemical characteristics was accounted by the variation amongst replicate plots rather than by land-use types. These results indicated that in order to detect significant effects of land-use change on soil biochemical characteristics in our nested experimental design, more replicate plots per landuse type should be sampled.

The aim of the third study was to differentiate direct land-use effects from indirect bottomup effects on below- and aboveground taxa. Generalized multilevel path models (a form of structural equation modeling) that allowed for direct and interactive effects of land-use with abiotic variables and bottom-up effects among biotic variables were constructed using data collected on plants, microorganisms, litter invertebrates, arboreal ants, birds and environmental parameters (soil and microclimatic properties). Results from the path models demonstrated that land-use change imposed direct effects on plants, belowground taxa at lower trophic levels (i.e., detritivores and herbivores) and arboreal ants, but almost all land-use impacts at the highest trophic levels of invertebrates and birds were bottom-up controlled. This study revealed that land-use change directly and indirectly drives large-scale ecological shifts, but the effects detected at the highest trophic levels were mostly dependent on lower trophic-level organisms.

The soil- $\mathrm{N}$ cycling rates and $\mathrm{N}$ pools measured in the first study were combined with parallel studies on $\mathrm{N}$-oxide emissions and $\mathrm{N}$ leaching, to generate a more holistic picture of the general soil$\mathrm{N}$ cycle in this converted landscape. Analysis on sample optimization was conducted on the soil biochemical characteristics in the top $0.5 \mathrm{~m}$ depth from the second study, to determine the minimum number of replicates per land-use type needed to detect significant differences between land uses within our experimental design. The soil components incorporated within the multilevel path models from the third study were extracted and direct relationships between these soil properties and ecosystem biodiversity and biomass were examined to better understand the role soil nutrient status plays within these transforming systems. Overall, the results from these three studies illustrate that soil nutrient status is an important ecosystem component, and changes in soil nutrient status due to land-use conversion can potentially affect biodiversity and ecosystem functioning. 


\section{Zusammenfassung}

Innerhalb der letzten zwei Jahrzehnte ist die Entwaldungsrate auf Sumatra, Indonesien stark gestiegen, dies geht einher mit eine Umwandlung von Tieflandwäldern in Ölpalm- (Elaeis guineensis) und Kautschukmonokulturplantagen (Hevea brasiliensis). Es wurde festgestellt, dass Landnutzungsänderungen in landwirtschaftlichen Systemen die Bodennährstoffbestände sowie die Umsatzrate von Bodennährstoffen senkt, dies kann zu einer Abhängigkeit vom Einsetzen von Düngemitteln führen, die nur eine zeitweise Verfügbarkeit von Nährstoffen gewährleistet. Des Weiteren bedroht die Umwandlung von Wald in Monokulturen die hohe Biodiversität, welche in tropischen Wäldern vorherrscht, was wiederum die Funktionsweise des Ökosystems beeinflusst. Der Schwerpunkt dieser Arbeit lag darin, die Auswirkungen der Landnutzungsänderung auf Bodennährstoffhaushalt und Ökosystemdynamiken festzustellen, sowie die Mechanismen die für die Veränderungen verantwortlich sind zu verstehen. Alle Drei Studien waren Teil eines großen interdisziplinären Projekts welches die ökologischen und sozialen Effekte von tropischen Landnutzungsveränderungen untersucht. Die Probenentnahme für jede Studie erfolgte in der Region von Jambi auf Sumatra, Indonesien - ein Gebiet das früher dicht bewaldet war, aber eine starke Entwaldung erfahren hat. Es wurden zwei Landschaften ausgesucht, die sich über ihre vorherrschende Bodentextur und ihren Bodentyp definieren und die Region natürlich repräsentieren: zum einen waren dies lehmige Acrisole und zum anderem tonige Acrisole. In den beiden Bodenlandschaften wurden vier Systeme untersucht: Tieflandregenwald und regenerierter Wald durchsetz mit Kautschukbäumen (hier benannt als „Jungle-rubber“) sowie Monokulturen von Kautschuk (Sein bis 17 Jahre alt) und Ölpalmen (Neun bis 16 Jahre alt).

Das Ziel der ersten Studie war zu bewerten, wie sich die Umsatzrate von Stickstoff (N) im Boden in Bezug auf die Umwandlung von Wald in Kautschuk- und Ölpalmplantagen verändert. Die Bruttoumsatzrate von Stickstoff im Boden wurde mit der ${ }^{15} \mathrm{~N}$-Verdünnungsmethode mit in situ Inkubation der Bodenbohrkerne bestimmt. In den Lehm-Acrisolen, in denen die Bodenfruchtbarkeit gering war, waren auch die mikrobielle Biomasse, die Bruttostickstoffmineralisation und die Immobilisierung von Ammonium $\left(\mathrm{NH}_{4}{ }^{+}\right)$gering und es wurden keine signifikanten Veränderungen durch die Landnutzung aufgezeigt. Die Ton-Acrisole welche eine höhere Ausgangsfruchtbarkeit, bezogen auf die Referenzflächen, aufwiesen, waren auch einen höheren Anteil an mikrobielle Biomassen sowie durch höhere $\mathrm{NH}_{4}{ }^{+}$Umwandlungsraten im Vergleich $\mathrm{zu}$ den Lehm-Acrisolen gekennzeichnet. In den Ton-Acrisolen hat die Umwandlung von Wald und Jungle-rubber in Kautschuk- und Ölpalmplantagen zu einer Verringerung der Bodenfruchtbarkeit geführt, was wiederum zu einer Reduzierung der mikrobiellen Biomasse und der $\mathrm{NH}_{4}{ }^{+}$-Umwandlungsraten 
beigetragen hat. Unsere Ergebnisse lassen annehmen, das je höher die Ausgangsbodenfruchtbarkeit und Stickstoffverfügbarkeit im Boden ist, desto höher ist die Reduktionen durch die Landnutzungsänderungen.

Das Ziel der zweiten Studie war es, Veränderungen biochemischer Charakteristika des Bodens sowie des Nährstoffbestandes bis $2 \mathrm{~m}$ Bodentiefe in den verschiedenen Landnutzungssystemen zu erfassen und die Proportionen der Gesamtvarianz der biochemischer Bodencharakteristika zu bestimmen, die durch die räumlichen Komponenten in unserem experimentellem Design hervorgerufen werden. Der Tongehalb beeinflusst die Bodenfruchtbarkeit und die größeren Nährstoffbestände wurden in den Referenzflächen der Ton-Acrisolen gefunden. Bewirtschaftungspraktiken in den veränderten Landnutzungssystemen übten den größten Einfluss auf Boden-pH, Basensättigung, extrahierbaren Phosphor und austauschbares Natrium aus. Die Mehrheit der biochemischen Bodencharakteristika und der Nährstoffbestände wurden nicht signifikant durch Landnutzungsänderungen verändert. Basierend auf der Varianzkomponentenanalyse der verschachtelten räumlichen Struktur des experimentellen Designs, wurde die Gesamtvarianz von vielen biochemischen Bodencharakteristika durch die Abweichungen zwischen replizierten Plots und nicht durch die unterschiedliche Landnutzung erklärt. Dieses Ergebnis deutet darauf hin, dass wenn man signifikante Effekte von Landnutzungsänderungen auf biochemische Bodencharakteristika feststellen will, die Stichprobenzahl replizierter Plots pro Landnutzungssystem erhöht werden muss.

Das Ziel der dritten Studie war es, zwischen direkten Landnutzungseffekten und indirekten „Bottom-up“-Effekten auf ober- und unterirdisch lebende Taxa zu differenzieren. Es wurden allgemeine „Multilevel path“- Modelle (eine Form von Strukturgleichungsmodellen), die eine Berechnung direkter und interaktiver Effekte von Landnutzung mit abiotischen Variablen und „Bottom-up“-Effekten zwischen biotischen Variablen zulassen, auf der Basis von Daten von Pflanzen, Mikroorganismen, Invertebraten der Streuschicht, baumbewohnende Ameisen, Vögeln und Umweltparametern (Boden- und Mikroklimaeigenschaften) entworfen. Die Ergebnisse der „Multilevel path“- Modelle zeigen, dass die Landnutzungsänderungen direkte Effekte auf Pflanzen, unterirdisch lebende Taxa einer niedrigen trophischen Ebene (z.B. Saprobionten und Herbivoren) und baumbewohnende Ameisen haben, fast alle Landnutzungsauswirkungen auf höhere trophische Ebenen von Invertebraten und Vögel waren jedoch „Bottom-up“-kontrolliert. Diese Studie lässt erkennen, dass Landnutzungsveränderungen, direkt und indirekt, ökologische Verschiebungen im großen Rahmen lenken. Die gefundenen Effekte auf höhere trophische Ebenen sind jedoch meistens von den Organismen der darunterliegenden trophischen Ebenen abhängig. 
Die Stickstoffumsatzraten im Boden und der Umfang der Stickstoffpools, welche in der ersten Studie gemessen wurden, wurden parallel mit Studien zur Stickstoffoxidemission und Stickstoffauswaschung des Bodens durchgeführt, um ein ganzheitliches Bild des Stickstoffhaushaltes in den veränderten Landschaft zu erhalten. Analysen zur Probenoptimierung wurden für die biochemischen Bodencharakteristika der oberen Bodenschicht bis 0,5 m aus der zweiten Studie durchgeführt, um festzustellen was die minimale Anzahl an Replikaten pro Landnutzungstyp ist, um signifikante Unterschiede zwischen den Landnutzungssystemen in unserem experimentellen Design festzustellen. Die Bodenkomponenten die in die „Multilevel path“Modelle integriert waren, wurden erfasst und direkte Zusammenhänge zwischen diesen Bodeneigenschaften und der Biodiversität des Ökosystems und den Biomassen wurden untersucht, um ein besseres Verständnis davon zu bekommen, welche Rolle Bodennährstoffbeständen für die transformierten Systeme spielen. Insgesamt zeigen die Ergebnisse der drei Studien, dass die Bodennährstoffbestände eine wichtige Komponente des Ökosystems darstellt und Veränderungen der Bodennährstoffbestände durch Landnutzungsänderungen Auswirkungen auf die Biodiversität und die Funktionsweise des Ökosystems haben können. 


\section{Chapter 1}

\section{General Introduction}

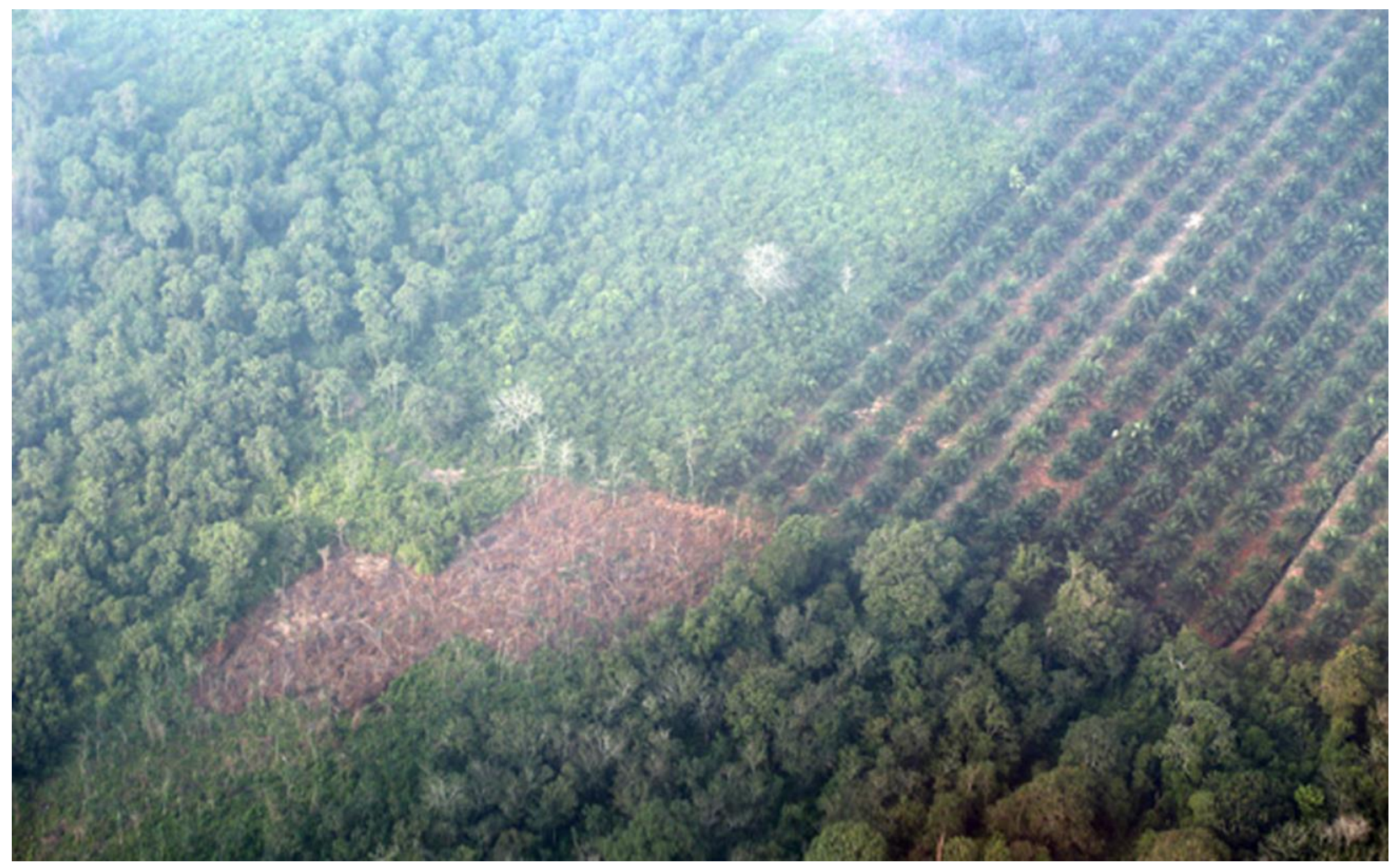

Picture 1.1. Oil palm encroaching on native forest in Riau Province, Sumatra, Indonesia. Image source: Rhett A. Butler (mongabay.com 2014)

As you fly over the island of Sumatra, the landscape you expect to view beneath you, filled with bursts of green giants, trees that look as if they could reach the sky, has morphed into a uniform pattern of squat sprouting palms lined-up like soldiers ready for battle. A haze encircles these sprouts, creating an atmosphere of gray and green dullness. In the distance a tower of smoke rises to the sky, representing the battlefield from which the army of palms grew, where the life within the forest ends and the change in landscape begins. 


\subsection{Land-use change in Southeast Asia}

Deforestation in the tropics has become a global environmental concern. Between 1980 and 2000 , over $80 \%$ of newly established agricultural areas were created at the expense of intact or degraded tropical forests (Gibbs et al. 2010). In the future, it is expected that the expansion of croplands will primarily occur at the frontier of the world's remaining tropical forests (Tilman et al. 2001; Gibbs et al. 2010; Lambin and Meyfroidt 2011; Koh and Lee 2012). Losses of large tracts of tropical forests have been shown to negatively impact both biotic and abiotic functioning of these ecosystems (Tilman et al. 2001; Fitzherbert et al. 2008). Tropical forests not only hold genetically diverse plant and animal communities, but also store approximately $55 \%$ of the global forest carbon (C) stock (Pan et al. 2011). In previous decades, Brazil maintained the highest deforestation rates worldwide. However in 2012, Indonesia took the lead, losing a total of 0.84 million hectares (ha) of forest (Margono et al. 2014).

Human modification of tropical forests in Indonesia has spanned over centuries (Feintrenie and Levang 2009). But accelerated forest modification in Indonesia began during the early 1900's, when the rubber (Hevea brasiliensis) seed was introduced and inter-planted within the native forest (Guyon et al. 1993). However, the yield of these agroforest systems could not sustain the growing population and the increased demand for agricultural resources. In the latter half of the last century, monoculture plantations of rubber and oil palm (Elaeis guineensis) began to dominate the landscape in Indonesia. Over the past thirty years, the area of harvested land in Indonesia under rubber plantations has increased from 1.8 million ha to 3.5 million ha, and the area of harvested land under oil palm plantations has increased exponentially from 673,000 ha to $\sim 7.0$ million ha (FAOSTAT 2015). During this time, the production of crude palm oil more than quadrupled in Indonesia, and in 2008, Indonesia surpassed Malaysia to become the number one producer of palm oil worldwide (FAOSTAT 2015). Crops such as oil palm and rubber are important livelihoods for smallholders in Indonesia, and to halt the expansion of these crops altogether is unsustainable for both the Indonesian people and the Indonesian economy. Therefore, it is important to understand the longterm effects produced by continued deforestation and subsequent cultivation on these transforming systems. With this knowledge-and the requisite will-it may be possible to find a sustainable balance between the needs of humans and nature.

A number of scientific studies have investigated changes in aboveground biodiversity (see Wilcove et al. 2013). Likewise, there has been considerable research quantifying greenhouse gas emissions from these transforming systems (e.g., Danielsen et al. 2008; Carlson et al. 2012). 
Focusing on land-use change effects on aboveground systems is important, however, it is also important to understand alterations belowground. Soil represents a dynamic system that holds the key to maintaining productivity of aboveground systems, which, in turn, helps to sustain life on Earth. Consequently, determining the effects of land-use on soil biological, chemical and physical parameters helps us to understand how nutrient cycling or microbial communities are affected by land-use change, but also provides insight into the overall functioning of these ecosystems.

\subsection{Soils and land-use change}

Within soil lies a diverse and active underground world that rivals the complexity of any ecosystem aboveground. Soil is a dynamic reservoir of nutrients and organisms that can support ecosystems ranging from forests to grasslands. In its natural state, it is able to maintain a stable balance of both nutrients and life or soil sustainability (Amundson et al. 2015). This natural state involves equal inputs and outputs of nutrients as well as efficient nutrient recycling mechanisms; however disruptions to these processes can upset this balance and alter soil's sustainability.

Human activity generates the largest disturbances to the soil system. Removal of aboveground biomass either through burning or logging disrupts soil sustainability by decreasing organic matter inputs, reducing plant uptake of nutrients, increasing erosion, and increasing nutrient leaching (Uhl and Jordan 1984; Malmer and Grip 1994; Hölscher et al. 1997; McGrath et al. 2001). However, converted systems in Amazonia that underwent natural restoration were able to recover a large portion of the nutrients lost less than a decade following conversion, which illustrates the resilience of soil sustainability (Uhl and Jordan 1984). But continued human modification through agricultural management practices may continue to disturb soil sustainability, by repeated cycles of removing nutrient inputs through harvest (Hölscher et al. 1997), and externally adding nutrients through fertilization. Though short-term soil nutrient inputs (i.e., fertilization) can often improve a soil's nutrient status, it has been shown that continued cultivation overtime decreases soil fertility (Corre et al. 2006; Davidson et al. 2007; Zhang et al. 2007) as well as increases nutrient losses via groundwater leaching (Dechert et al. 2005) and emissions of climate relevant trace gases from the soil (Veldkamp et al. 2008). Therefore, this continued challenge to soil sustainability could potentially unhinge this balance and have consequences that might take years to alleviate.

While it is true that natural soil systems in general are able to maintain themselves quite well, there is very little uniformity in soil characteristics and processes among these systems. Soil biochemical properties exhibit high spatial variability (Parkin 1993; Pennock and Corre 2001; 
Powers and Schlesinger 2002) due to the variation in controlling factors, such as climate, geology and biota (Jenny 1941). This implies that one soil system's response to land-use change will most certainly vary with another's. In order to quantify and assess changes accurately in soil properties, such as soil organic carbon (SOC) or soil nitrogen (N) cycling, we must not only examine effects of land-use change on these characteristics, but also their spatial distribution. Studies determining the effects of spatial components on a range of soil biochemical properties in Southeast Asia are limited, and a majority of studies investigating this topic focus purely on spatial distribution of SOC (e.g., Powers and Schlesinger 2002; Chaplot et al. 2010; de Blécourt 2013). This demonstrates the need to determine the effects of spatial variation on a range of soil nutrient stocks in order to extrapolate effects of land-use change across larger spatial scales (Powers and Schlesinger 2002).

\subsection{The internal soil nitrogen cycle}

Nitrogen is an integral part of life on earth and influences many aspects of species composition and diversity, as well as ecosystem functioning (Schlesinger 1997; Vitousek et al. 1997). The global $\mathrm{N}$ cycle describes the movement of $\mathrm{N}$ between the atmosphere, oceans and land. An important component of the global $\mathrm{N}$ cycle is the internal soil- $\mathrm{N}$ cycle, in which soil $\mathrm{N}$ is converted from one chemical form to another and made available to be transferred between ecosystem pools (Hart et al. 1994). The internal soil-N cycle is primarily driven by microorganisms, and consists of both mineral $\mathrm{N}$ production and $\mathrm{N}$ retention processes (Fig. 1.1 below). Nitrogen mineralization and nitrification are the processes that produce bioavailable forms of $\mathrm{N}$ in the soil. Mineralization is the transformation of organic $\mathrm{N}$ in soil to inorganic forms, such as ammonium $\left(\mathrm{NH}_{4}{ }^{+}\right)$, and nitrification is the conversion of either $\mathrm{NH}_{4}{ }^{+}$or organic $\mathrm{N}$ into nitrate $\left(\mathrm{NO}_{3}{ }^{-}\right)$via oxidation. Nitrogen retention processes include the assimilation of available $\mathrm{N}$ by plants, the immobilization of both organic and inorganic forms of $\mathrm{N}$ in the microbial biomass pool and dissimilatory nitrate reduction to ammonium (DNRA). Dissimilatory $\mathrm{NO}_{3}{ }^{-}$reduction to $\mathrm{NH}_{4}{ }^{+}$is an anaerobic process, which rapidly reduces $\mathrm{NO}_{3}$ into nitrite $\left(\mathrm{NO}_{2}^{-}\right)$and then to $\mathrm{NH}_{4}{ }^{+}$and is an important $\mathrm{N}$ retention process in humid tropical forests (Silver et al. 2001).

The functioning of each process within the internal soil-N cycle subsequently affects the $\mathrm{N}$ status of an ecosystem. In general, lowland tropical forests are characterized by high $\mathrm{N}$ availability and rapid soil-N cycling rates (Vitousek and Sanford 1986; Vitousek and Matson 1988), which may lead to increased losses of $\mathrm{N}$ from these systems (Fig. 1.1; Hedin et al. 2009). The conservation of $\mathrm{N}$ within a system can be determined through the quantification of $\mathrm{NH}_{4}{ }^{+}$and $\mathrm{NO}_{3}{ }^{-}$production and retention processes. The ${ }^{15} \mathrm{~N}$ pool dilution technique as described by Davidson et al. (1991) is 
considered one of the more efficient techniques for measuring the different processes involved within the internal soil-N cycle (Fig. 1.1; Hart et al. 1994). Unlike measuring net rates, which fail to provide information on soil $\mathrm{N}$ retention, the ${ }^{15} \mathrm{~N}$ pool dilution technique quantifies both $\mathrm{N}$ production and retention processes by injecting ${ }^{15} \mathrm{~N}$ labeled solutions into intact soil cores. Gross rates of the internal soil- $\mathrm{N}$ cycle can then be calculated from the dilution of ${ }^{15} \mathrm{~N}$ by incoming ${ }^{14} \mathrm{~N}$ over a 24-hour incubation period (Hart et al. 1994). Soil processes, such as those associated with N, contribute to the overall soil sustainability discussed earlier. In particular, $\mathrm{N}$ made available by these processes becomes accessible to plants, which aid in structuring ecosystems (Scherber et al. 2010). Thus, it is important to understand not only the role that soil processes play within an entire ecosystem but also how these soil processes might be altered by human interventions.

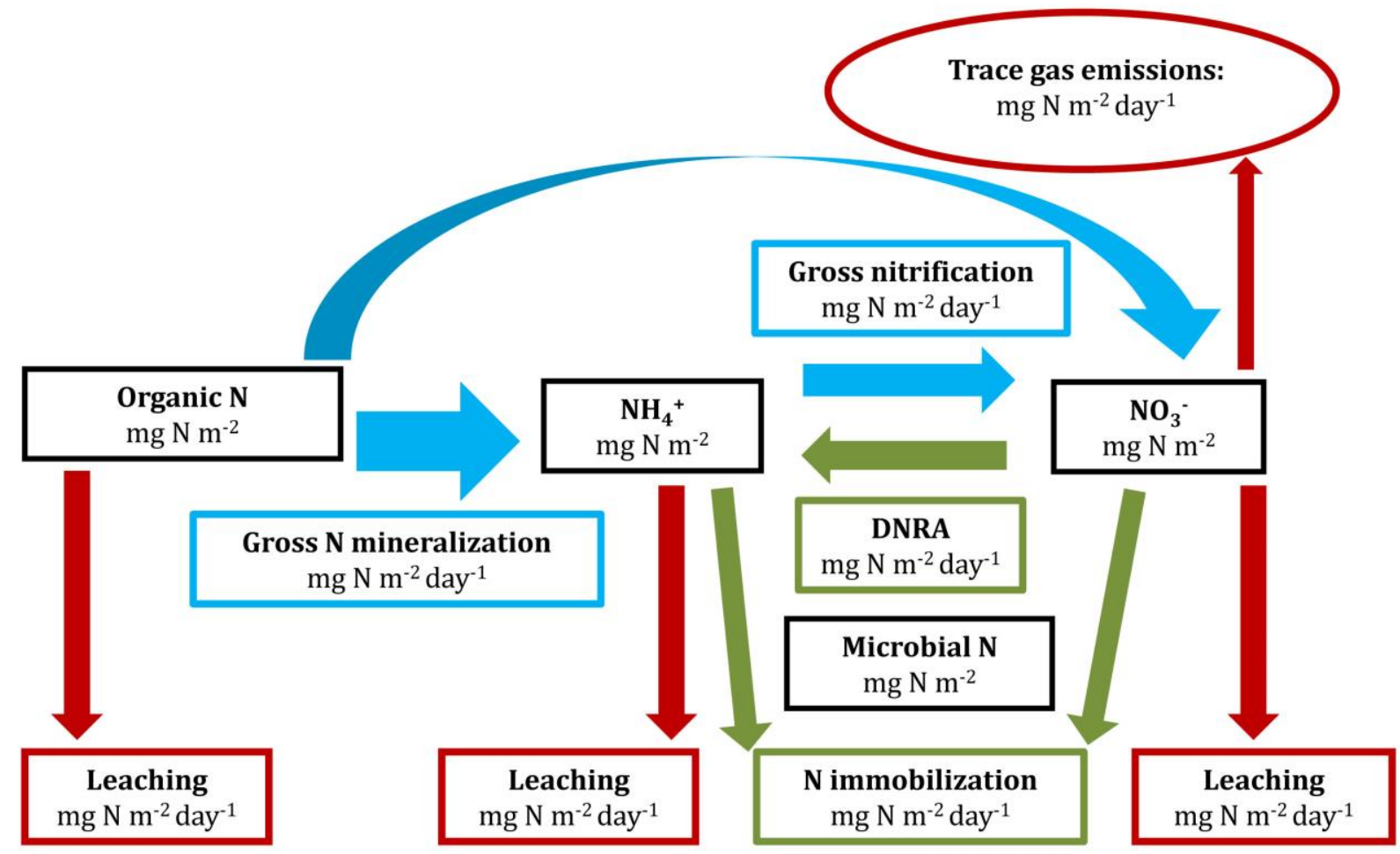

Figure 1.1. Representation of the soil- $\mathrm{N}$ cycling rates and soil $\mathrm{N}$ pools measured using the ${ }^{15} \mathrm{~N}$ pool dilution technique (Davidson et al. 1991; Hart et al. 1994) as well as pathways for soil N losses. The black boxes represent soil $\mathrm{N}$ pools. The blue boxes and arrows represent mineral $\mathrm{N}$ production rates in the soil. The green boxes and arrows represent $\mathrm{N}$ retention rates in the soil. The red boxes and arrows represent $\mathrm{N}$ losses from the soil. 


\subsection{A call for multifunctionality}

Increasingly, terms such as "multifunctional" and "multitrophic" are becoming more common in current scientific literature. Ecological researchers are beginning to recognize the importance of linking ecosystem diversity with environmental processes. Scientists have always acknowledged the complexity of natural systems, but the need to determine or quantify this complexity is becoming crucial in order to understand how particular systems function-especially under ever-changing environmental conditions. Many studies have found that biodiversity loss affects processes within an ecosystem, as well as impacting the goods and services these ecosystems provide (Cardinale et al. 2012). However, previous research has largely focused on the effects of changes within individual groups of organisms, trophic levels, or ecosystem processes and a result of many of these studies is a challenge for a more comprehensive look into ecosystem multifunctionality (Duffy et al. 2007; Hector and Bagchi 2007; Tylianakis et al. 2008).

Analytical modeling techniques, such as structural equation modeling (SEM) or pathways analysis, are useful tools to examine causation and mediating mechanisms linking one variable to another (Shipley et al. 2009; Scherber et al. 2010; Clough 2012; Laliberté and Tylianakis 2012). A recent study (Scherber et al. 2010) using SEM and data from a long-term biodiversity experiment was able to establish links between plant and invertebrate diversity. Scherber et al. found that plant diversity clearly structured invertebrate communities, with the strongest effects at the lower trophic levels, leading to indirectly mediated bottom-up trophic cascades on the higher trophic levels. Insights regarding ecosystem structuring, such as those found in the Scherber et al. (2010) study, are important in terms of biological management and restoration techniques, as they illustrate which communities are strongest in restoring and/or maintaining ecosystem functioning. Yet once again, this and the majority of studies modeling biodiversity effects on ecosystem functioning focus predominantly on aboveground systems and processes (Bardgett et al. 2014; Wagg et al. 2014). As previously discussed, belowground biodiversity and ecosystem processes are intimately linked to aboveground systems and understanding the linkages between these systems involves determining how interactions between biotic and abiotic components structure communities and drive ecosystem properties (Wardle et al. 2004). Therefore, large interdisciplinary research projects (such as the CRC 990: EEFForTs project described below) with well-replicated experimental systems focusing on both below- and aboveground diversity and associated environmental processes are the ideal vehicle for modeling ecosystem functioning and its effects on structuring communities within those systems. 


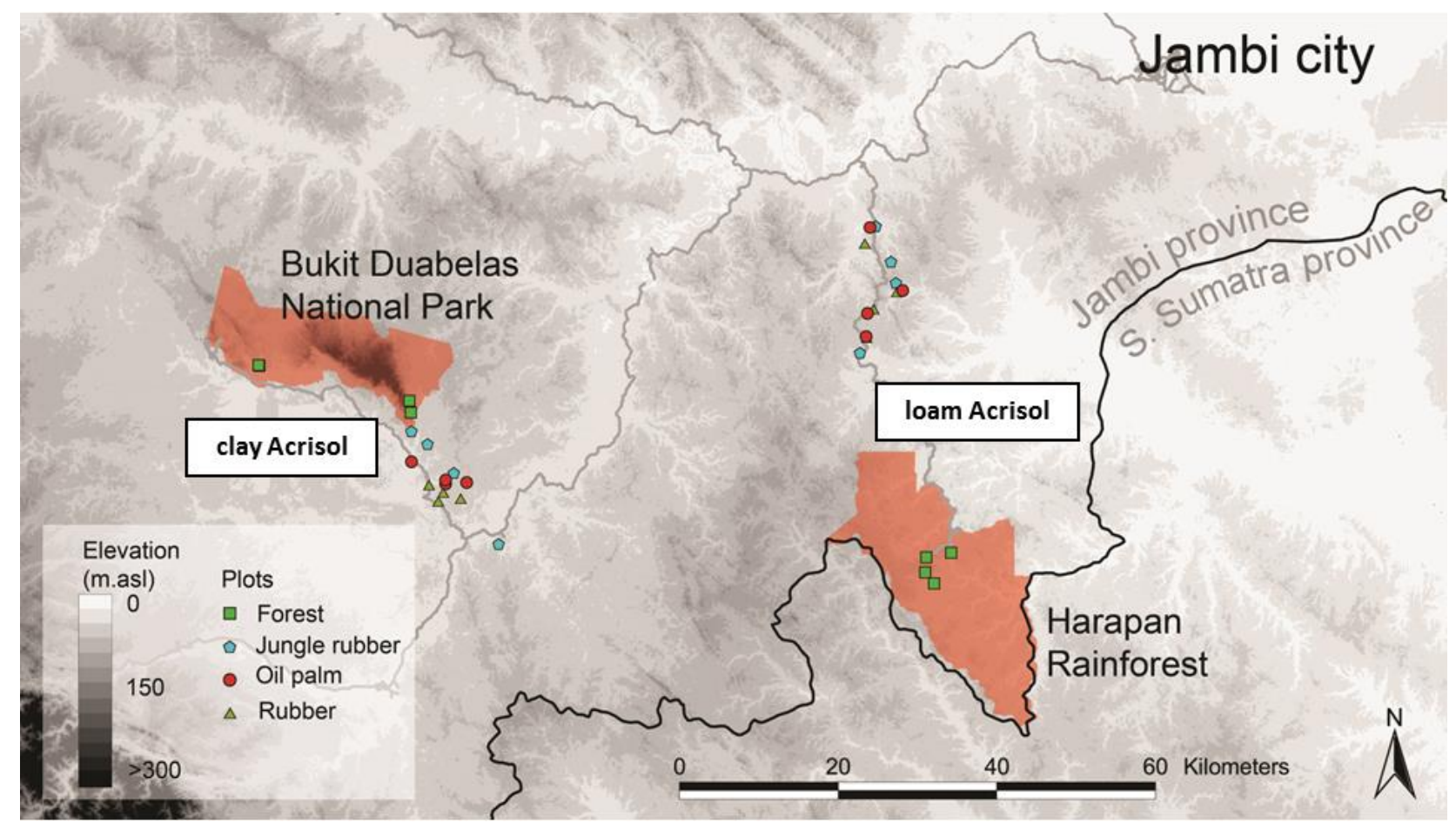

Figure 1.2. Map of study area located in Jambi, Sumatra, Indonesia. Each of the four land-use types were represented with four replicate plots and plots were clustered in two different landscapes classified by dominant soil texture and soil type: clay Acrisol soil (located in Bukit Duabelas region with forest sites in the National Park (area shaded in orange)) and loam Acrisol soil (located in Harapan region with forest sites in the PT REKI Harapan protected area (area shaded in orange)). Map created by Oliver van Straaten.

\subsection{The EEFForTs Project}

The DFG funded Collaborative Research Center 990 (CRC 990), entitled Ecological and Socioeconomic Functions of Tropical Lowland Rainforest Transformation Systems (EEFForTs) is a long-term interdisciplinary research project that investigates the effects of land-use change on environmental processes, biodiversity and human dimensions. The aim of the project is to provide scientific knowledge on how to maintain and enhance vital ecosystem functions within tropical forests and converted agricultural systems at a landscape scale, while promoting human welfare. Project sites were located in Jambi Province, Sumatra, Indonesia in two distinct lowland soil landscapes (Fig. 1.2). In order to determine the effects of land-use conversion on environmental, biological and human dimensions, four land-use systems common to the area were selected (Picture 1.2):

- lowland forest,

- rubber interspersed in forest or jungle rubber, 
- monoculture plantations of rubber and

- monoculture plantations of oil palm.
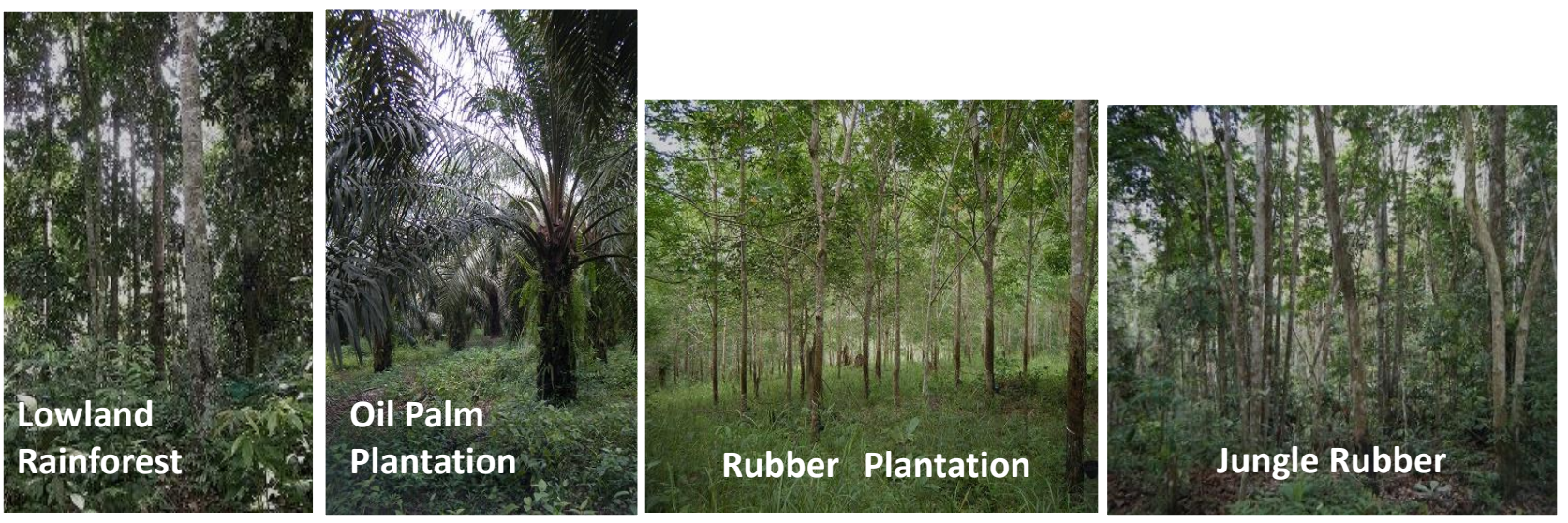

Picture 1.2. Four land-use types common in Jambi Province, Sumatra, Indonesia, selected to be examined by the CRC 990: EEFForTs project.

Within the CRC 990: EEFForTs project, sub-groups examined a broad range of environmental and social parameters, including belowground and aboveground diversity and biomass, soil fertility, water, nutrient and greenhouse gas fluxes, and economic, social and political issues related to land-use conversion in the region. This provided an excellent foundation for the third study within this work, which incorporated a large portion of the biodiversity and environmental parameters and investigated the direct and indirect effects of land-use change at the ecosystem level. The CRC 990: EEFForTs project is a collaboration between Georg-August University Göttingen and four Indonesian universities-Agricultural University Bogor (IPB), University of Jambi, University of Tadulako Palu and University of Brawijaya Malang.

\subsection{Aims and hypotheses}

The first two studies were conducted solely within the subproject A05 of the CRC 990: EEFForTs research project. The focus of subproject A05 was to address the impacts of lowland forest conversion to agricultural land uses on changes in soil chemical and physical properties and soil-N cycling rates across two texturally distinct soil landscapes in Jambi Province, Sumatra, Indonesia. The final study was conducted in collaboration between subprojects A05 and B01 and aimed at linking scientific knowledge collected throughout Phase 1 of the CRC 990: EEFForTs project in order examine the effects of land-use change and environmental processes on biodiversity at the ecosystem level. 


\section{Study 1: Soil nitrogen-cycling responses to conversion of lowland forests to oil palm and rubber plantations in Sumatra, Indonesia}

The aim of the first study was to assess changes in soil mineral $\mathrm{N}$ production, as indices of soil $\mathrm{N}$ availability, and mineral $\mathrm{N}$ retention processes with land-use change.

The following hypotheses were tested in this study:

Hypotheses:

1. gross soil-N cycling rates in the reference land uses will be higher in the clay than loam Acrisol soils

2. gross soil-N cycling rates will be higher in the reference land uses (forest and jungle rubber) compared to the unfertilized land use (rubber plantations) and will be intermediate in the fertilized converted land use (oil palm plantations).

\section{Study 2: Spatial variability surpasses land-use change effects on soil biochemical properties of converted lowland landscapes in Sumatra, Indonesia}

The aim of the second study was to assess changes in soil nutrient stocks down to $2 \mathrm{~m}$ depth with land-use change and to determine the proportions of overall variance in soil biochemical characteristics that are accounted for by the spatial components within our nested experimental design.

The following hypotheses were tested in this study:

\section{Hypotheses:}

1. soil biochemical characteristics and soil nutrient stocks in the reference land uses will be higher in the clay than the loam Acrisol soils

2. if effects of land-use change are detectable, they will be highest in the reference land uses (forest and jungle rubber), lowest in the unfertilized converted land use (rubber plantations) and intermediate in the fertilized converted land use (oil palm plantations)

3. it is expected that in cases where land-use change effects on soil biochemical characteristics are statistically not detectable, the proportions of the overall variance on soil biochemical characteristics would be highest between landscapes, followed by amongst replicate plots within landscapes and least by amongst subplots within replicate plots. 


\section{Study 3: Tropical land use imposes direct and cascading impacts on biodiversity from bacteria to birds}

The aim of the third study was to differentiate direct land-use effects from indirect bottomup effects on below- and aboveground taxa including plants, microorganisms, invertebrates and birds by partitioning effects into those caused by land-use change and environmental parameters (direct effects) versus biotic interactions (indirect effects).

The following hypotheses were tested in this study:

Hypotheses:

1. the direct land-use effects hypothesis assumes land-use change will directly impact all biotic groups, notwithstanding any bottom-up trophic effects.

2. the cascading land-use effects hypothesis assumes that all impacts of land-use change on biota at higher trophic levels will propagate via bottom-up processes. 


\section{References}

Amundson R, Berhe AA, Hopmans JW, Olson C, Sztein AE, Sparks DL. Soil and human security in the $21^{\text {st }}$ century. Science. 2015; 348: doi: 10.1126/science.1261071.

Bardgett RD, van der Putten WH. Belowground biodiversity and ecosystem functioning. Nature. 2014; 515: 505-511.

de Blécourt M. Impacts of land use and biophysical properties on soil carbon stocks in southern Yunnan, China (Unpublished doctoral dissertation). Georg-August University Göttingen, Germany; 2013.

Cardinale BJ, Duffy JE, Gonzalez A, Hooper DU, Perrings C, Venail P, et al. Biodiversity loss and its impact on humanity. Nature. 2012; 486: 59-67.

Carlson KM, Curran LM, Asner GP, McDonald Pittman A, Trigg SM, Adeney JM. Carbon emissions from forest conversion by Kalimantan oil palm plantations. Nat Clim Chang. 2012; doi: 10.1038/NCLIMATE1702.

Chaplot V, Bouahom B, Valentin C. Soil organic carbon stocks in Laos: spatial variations and controlling factors. Glob Chang Biol. 2010; 16: 1380-1393.

Clough Y. A generalized approach to modeling and estimating indirect effects in ecology. Ecology. 2012; 93: 1809-1815.

Corre MD, Dechert G, Veldkamp E. Soil nitrogen cycling following montane forest conversion in Central Sulawesi, Indonesia. Soil Sci Soc Am J. 2006; 70: 359-366.

Danielsen F, Beukema H, Burgess ND, Parish F, Brühl CA, Donald, PF, et al. Biofuel plantations on forested lands: double jeopardy for biodiversity and climate. Conserv Bio. 2008; 23: 348-358.

Davidson EA, Reis de Carvalho CJ, Figueira AM, Ishida FY, H.B. Ometto JP, Nardoto GB, et al. Recuperation of nitrogen cycling in Amazonian forests following agricultural abandonment. Nature. 2007; 447: 995-999.

Davidson EA, Hart SC, Shanks CA, Firestone MK. Measuring gross nitrogen mineralization, immobilization, and nitrification by ${ }^{15} \mathrm{~N}$ isotopic pool dilution in intact soil cores. J Soil Sci. 1991; 42: 335-349.

Dechert G, Veldkamp E, Brumme R. Are partial nutrient balances suitable to evaluate nutrient sustainability of land use systems? Results from a case study in Central Sulawesi, Indonesia. Nutr Cycl Agroecosys. 2005; 72: 201-212.

Duffy JE, Cardinale BJ, France KE, McIntyre PB, Thébault E, Loreau M. The functional role of biodiversity in ecosystems: incorporating trophic complexity. Ecol Lett. 2007; 10: 522-538.

Food and Agricultural Organization. FAOSTAT. Available:

http://faostat.fao.org/site/339/default.aspx. Accessed 29 June, 2015. 
Feintrenie L, Levang P. Sumatra's rubber agro-forests: Advent, rise and fall of a sustainable cropping system. Small Scale For. 2009; 8: 323-335.

Fitzherbert EB, Struebig MJ, Morel A, Danielsen F, Brühl CA, Donald, PF, et al. How will oil palm expansion affect biodiversity? Trends Ecol Evol. 2008; 23: 538-545.

Gibbs HK, Ruesch AS, Achard F, Clayton MK, Holmgren P, Rmankutty N, Foley JA. Tropical forests were the primary sources of new agricultural land in the 1980s and 1990s. P Natl Acad Sci USA. 2010; 107: 16732-16737.

Gouyon A, de Foresta H, Levang P. Does 'jungle rubber' deserve its name? An analysis of rubber agroforestry systems in southeast Sumatra. Agrofor Syst. 1993; 22: 181-206.

Hart SC, Stark JM, Davidson EA, Fireston MK. Nitrogen mineralization, immobilization, and nitrification. In: Weaver RW, Angle S, Bottomley P, Bezdicek D, Smith S, Tabatabai A, Wollum A, editors. Methods of soil analysis part 2, microbiological and biochemical properties. Madison, WI: Soil Science Society of America; 1994. pp. 985-1018.

Hector A, Bagchi R. Biodiversity and ecosystem multifunctionality. Nature. 2007; 448: 188-191.

Hedin LO, Brookshire ENJ, Menge DNL Barron AR. The nitrogen paradox in tropical forest ecosystems. Annu Rev Ecol Evol Syst. 2009; 40: 613-635.

Hölscher D, Ludwig B, Möller RF, Fölster H. Dynamic of soil chemical parameters in shifting agriculture in the Eastern Amazon. Agr Ecosyst Environ. 1997; 66: 153-163.

Jenny H. Factors of soil formation: A system of quantitative pedology. New York, USA: McGraw-Hill; 1941.

Koh LP, Lee TM. Sensible consumerism for environmental sustainability. Biol Conserv. 2012; 151: 36.

Laliberté E, Tylianakis JM. Cascading effects of long-term land-use change on plant traits and ecosystem functioning. Ecology. 2012; 93: 145-155.

Lambin EF, Meyfroidt P. Global land-use change, economic globalization, and the looming land scarcity. P Natl Acad Sci USA. 2011; 108: 3465-3472.

Malmer A, Grip H. Converting tropical rainforest to forest plantation in Sabah, Malaysia: II. Effects on nutrient dynamics and net losses in streamwater. Hydrol Process. 1994; 8: 195-209.

Margono BA, Potapov PV, Turubanova S, Stolle F, Hansen MC. Primary forest cover loss in Indonesia over 2000-2012. Nat Clim Chang. 2014; doi:10.1038/NCLIMATE2277.

McGrath DA, Smith CK, Gholz HL, de Assis Oliveira F. Effects of land-use change on soil nutrient dynamics in Amazonia. Ecosystems. 2001; 4: 625-645.

Pan Y, Birdsey RA, Fang J, Houghton R, Kauppi PE, Kurz WA, et al. A large persistent carbon sink in the world's forests. Science. 2011; 333: 988-993. 
Parkin TB. Spatial variability of microbial processes in soil - a review. J Environ Qual. 1993; 22: 409417.

Pennock DJ, Corre MD. Development and application of landform segmentation procedures. Soil Till Res. 2001; 58: 151-162.

Powers JS, Schlesinger WH. Relationships among soil carbon distributions and biophysical factors at nested spatial scales in rain forests of northeastern Costa Rica. Geoderma. 2002; 109: 165-190.

Scherber C, Eisenhauer N, Weisser WW, Schmid B, Voigt W, Fischer M, et al. Bottom-up effects of plant diversity on multitrophic interactions in a biodiversity experiment. Nature. 2010; 468: 553556.

Schlesinger WH. Biogeochemistry: an analysis of global change. $2^{\text {nd }}$ ed. San Diego, CA: Academic Press; 1997.

Shipley B. Confirmatory path analysis in a generalized multilevel context. Ecology. 2009; 90: 363368.

Silver WL, Herman DJ, Firestone MK. Dissimilatory nitrate reduction to ammonium in upland tropical forest soils. Ecology. 2001; 82: 2410-2416.

Tilman D, Fargione J, Wolff B, D'Antonio C, Dobson A, Howarth R, Schindler D, Schlesinger WH, Simberloff D, Swackhamer D. Forecasting agriculturally driven global change. Science. 2001; 292: 281-284.

Tylianakis JM, Didham RK, Bascompte J, Wardle DA. Global change and species interactions in terrestrial ecosystems. Ecol Lett. 2008; 11: 1351-1363.

Uhl C, Jordan CF. Succession and nutrient dynamics following forest cutting and burning in Amazonia. Ecology. 1984; 65: 1476-1490.

Veldkamp E, Purbopuspito J, Corre MD, Brumme R, Murdiyarso D. Land use change effects on trace gas fluxes in the forest margins of Central Sulawesi, Indonesia. J Geophys Res. 2008; doi:10.1029/2007JG000522.

Vitousek PM, Farrington H. Nutrient limitation and soil development: experimental test of biogeochemical theory. Biogeochemistry. 1997; 37: 63-75.

Vitousek PM, Matson PA. Nitrogen transformation in a range of tropical forest soils. Soil Biol Biochem. 1988; 20: 361-367.

Vitousek PM, Sanford R. Nutrient cycling in moist tropical forest. Annu Rev Ecol Syst. 1986; 17: 137167.

Wagg C, Bender SF, Widmer F, van der Heijden GA. Soil biodiversity and soil community composition determine ecosystem multifunctionality. P Natl Acad Sci USA. 2014; 111: 5266-5270.

Wardle DA, Bardgett, RD, Klironomos JN, Setälä H, van der Putten WH, Wall DH. Ecological linkages between aboveground and belowground biota. Science. 2004; 304: 1629-1633. 
Wilcove DS, Giam X, Edwards DP, Fisher B, Koh LP. Navjot's nightmare revisited: logging, agriculture, and biodiversity in Southeast Asia. Trends Ecol Evol. 2013; 28: 531-540.

Zhang H, Zhang G-L, Zhao Y-G, Zhao W-J, Qi Z-P. Chemical degradation of a Ferralsol (Oxisol) under intensive rubber (Hevea brasiliensis) farming in tropical China. Soil Till Res. 2007; 93: 109-116. 


\title{
Chapter 2
}

\section{Soil nitrogen-cycling responses to conversion of lowland forests to oil palm and rubber plantations in Sumatra, Indonesia}

\author{
Kara Allen, Marife D. Corre, Aiyen Tjoa, Edzo Veldkamp
}

Published in PLoS ONE; doi:10.1371/journal.pone.0133325

\begin{abstract}
Rapid deforestation in Sumatra, Indonesia is presently occurring due to the expansion of palm oil and rubber production, fueled by an increasing global demand. Our study aimed to assess changes in soil-N cycling rates with conversion of forest to oil palm (Elaeis guineensis) and rubber (Hevea brasiliensis) plantations. In Jambi Province, Sumatra, Indonesia, we selected two soil landscapes - loam and clay Acrisol soils - each with four land-use types: lowland forest and forest with regenerating rubber (hereafter, "jungle rubber") as reference land uses, and rubber and oil palm as converted land uses. Gross soil-N cycling rates were measured using the ${ }^{15} \mathrm{~N}$ pool dilution technique with in-situ incubation of soil cores. In the loam Acrisol soil, where fertility was low, microbial biomass, gross $\mathrm{N}$ mineralization and $\mathrm{NH}_{4}+$ immobilization were also low and no significant changes were detected with land-use conversion. The clay Acrisol soil which had higher initial fertility based on the reference land uses (i.e. higher $\mathrm{pH}$, organic $\mathrm{C}$, total $\mathrm{N}$, effective cation exchange capacity (ECEC) and base saturation) ( $\mathrm{P} \leq 0.05-0.09)$ had larger microbial biomass and $\mathrm{NH}_{4}{ }^{+}$ transformation rates $(\mathrm{P} \leq 0.05)$ compared to the loam Acrisol soil. Conversion of forest and jungle rubber to rubber and oil palm in the clay Acrisol soil decreased soil fertility which, in turn, reduced microbial biomass and consequently decreased $\mathrm{NH}_{4}{ }^{+}$transformation rates $(\mathrm{P} \leq 0.05-0.09)$. This was further attested by the correlation of gross $\mathrm{N}$ mineralization and microbial biomass $\mathrm{N}$ with ECEC, organic $C$, total $N(R=0.51-0.76 ; P \leq 0.05)$ and $C: N$ ratio $(R=-0.71--0.75, P \leq 0.05)$. Our findings suggest that the larger the initial soil fertility and $\mathrm{N}$ availability, the larger the reductions upon landuse conversion. Because soil $\mathrm{N}$ availability was dependent on microbial biomass, management practices in converted oil palm and rubber plantations should focus on enriching microbial biomass.
\end{abstract}




\subsection{Introduction}

Lowland tropical forests of Southeast Asia are considered some of the most diverse and carbon rich forests in the world; however, degradation and subsequent conversion of these forests is occurring at rapid rates. In 2012, Indonesia surpassed Brazil in total forest loss, losing 0.84 million hectares (ha) of forest of which 51\% were lowland forests (Margano et al. 2014). Sumatra, Indonesia, has been enduring deforestation for decades. Over the past 30 years, Sumatra island alone has lost on average approximately 550,000 ha of forest per year with $85 \%$ of these losses occurring in lowland regions (Laumonier et al. 2010). Lowland rainforests are especially vulnerable to degradation and conversion because of easy access and a majority of these forests have been converted to economically viable agricultural systems in order to keep up with the world's growing population and consumption needs. Historically in Sumatra, lowland forests were converted into agroforestry rubber systems, where rubber trees (Hevea brasiliensis) were planted within the natural forest landscape (Gouyon et al. 1993). However, this form of agriculture quickly morphed into complete conversion of entire forests into monoculture plantations, such as rubber and more recently oil palm (Elaeis guineensis) (Fitzherbert et al. 2008). From the period 2000-2013, the area of oil palm and rubber has increased by approximately five million ha and one million ha, respectively, across Indonesia (FAOSTAT 2014). Monoculture plantations will continue to dominate the landscape in Sumatra, with the Indonesian government goal to double oil palm production in the next ten years (Carlson et al. 2012).

Conversion of tropical forests does not only lead to decreases in biodiversity and drive climate change (Danielsen et al. 2008), but may also affect the short- and long-term nutrient status of the converted land-use systems (Klinge et al. 2004). Tropical lowland forests are considered rich in available nitrogen $(\mathrm{N})$, sustaining high $\mathrm{N}$ pools and exhibit high soil- $\mathrm{N}$ cycling rates (Hedin et al. 2009). Systems with large pools of available $\mathrm{N}$ are vulnerable to large $\mathrm{N}$ losses (Veldkamp et al. 2008). Forest converted to corn in Sulawesi, Indonesia, exhibits an initial increase in gross $\mathrm{N}$ mineralization rates upon forest conversion and is paralleled by increases in soil NO fluxes, $\mathrm{N}_{2} \mathrm{O}$ emissions and $\mathrm{N}$ leaching (Veldkamp et al. 2008). Over time, these continuously cultivated systems can experience decreases in available N, base cations and overall soil fertility (Dechert et al. 2004; Dechert et al. 2005; Corre et al. 2006; Veldkamp et al. 2008). Systems that are N fertilized or combine tree cash crops with $\mathrm{N}$-fixing tree species do not experience a similar decline in soil $\mathrm{N}$ availability (Dechert et al. 2004; Corre et al. 2006), but can experience losses in $\mathrm{N}$ via leaching and/or trace gas emissions (Dechert et al. 2005; Veldkamp et al. 2008). 
The internal soil- $\mathrm{N}$ cycle consists of processes that produce and retain mineral $\mathrm{N}$ in soil. Through quantifying gross rates of soil-N cycling, we can measure separately and compare mineral $\mathrm{N}$ production with retention processes, allowing us to understand better the changes in a system's soil N status. Mineral N production processes, such as gross N mineralization and gross nitrification, indicate soil $\mathrm{N}$ availability for both plants and microbial use (Davidson et al. 1991). Nitrogen immobilization contributes to the retention of mineral $\mathrm{N}$ in soil through $\mathrm{N}$ assimilation and turnover of soil microbial biomass, and thus minimizing losses (Corre et al. 2007). Dissimilatory nitrate reduction to ammonium (DNRA) is also an important retention process in humid tropical forests (Silver et al. 2001). DNRA transforms nitrate $\left(\mathrm{NO}_{3}^{-}\right.$) to the less mobile ammonium $\left(\mathrm{NH}_{4}{ }^{+}\right.$), and the rate of microbial transformation of $\mathrm{NH}_{4}{ }^{+}$is larger than the rates of microbial $\mathrm{NO}_{3}{ }^{-}$transformation in many tropical forests (Templer et al. 2008; Arnold et al. 2009). The most common factors affecting gross soil-N cycling in tropical forests are substrate quality and quantity (Corre et al. 2006; Corre et al. 2010), size of microbial biomass pool, availability of soil carbon (Hart et al. 1994; Sotta et al. 2008), and soil moisture content (Davidson et al. 1993). These factors, in turn, are influenced by altitude (Tanner et al. 1998), soil age or degree of soil development (Hall and Matson 2003), rainfall, temperature, elevation, presence or absence of organic layer (Arnold et al. 2009; Corre et al. 2010; Schuur and Matson 2001) and soil texture (Silver et al. 2000; Sotta et al. 2008).

Our study area was located in lowland forest landscapes in Sumatra, Indonesia with highly weathered Acrisol soils and similar climatic conditions. In such landscapes, the most important factor affecting soil $\mathrm{N}$ availability is soil texture. Clay soils are known to have higher nutrient ion availability, higher water holding capacity, and higher soil- $\mathrm{N}$ cycling rates compared to sandy soils (Silver et al. 2000; Sotta et al. 2008). Soils that are well drained (sands and loams) have lower rates of soil-N cycling and lower microbial biomass (Silver et al. 2000; Sotta et al. 2008). Therefore even with the added pressure of land-use conversion, soil-N cycling rates and losses should remain low, while the opposite would be expected from the more nutrient rich clay soils. For example, in Brazilian Amazon lowland forests on highly weathered Ferrasol soils, clay soils have higher cation exchange capacity, water holding capacity, microbial biomass and higher soil-N cycling rates or soil $\mathrm{N}$ availability than coarse-textured soils (Silver et al. 2000; Sotta et al. 2008). These are, in turn, a reflection of the higher soil fertility, plant productivity and decomposition rates in the clay Ferrasol soils (Silver et al. 2000).

On the other hand, because lowland forests are vulnerable to conversion for agricultural use, land-use change and its associated management practices (e.g., fertilization and liming) are additional important factors that can influence soil $\mathrm{N}$ availability in converted landscapes. Fertilization (as source of N, phosphorus (P) and potassium (K)) and liming (as source of calcium 
(Ca) and magnesium (Mg)) may augment the continuous decline of these nutrients with age of converted land uses (Corre et al. 2003; Ngoze et al. 2008). Studies of gross soil-N cycling processes in lowland Southeast Asian forests are few, while even fewer focus on land-use change effects on gross soil-N cycling processes. Only one study to our knowledge, investigates how land-use conversion affects gross soil-N cycling processes in montane forest soils in Sulawesi, Indonesia. The results of this study illustrate that cacao agroforestry systems exhibit comparable gross $\mathrm{NH}_{4}{ }^{+}$ transformation rates to the reference forest, which is attributed to $\mathrm{N}$-fixing tree species in such systems providing additional $\mathrm{N}$, while the oldest unfertilized corn sites exhibit the lowest gross $\mathrm{NH}_{4}{ }^{+}$ transformation rates (Corre et al. 2006). Age of converted land use also affects soil $\mathrm{N}$ availability with higher $\mathrm{NH}_{4}{ }^{+}$transformation rates in younger compared to older unfertilized corn sites (Corre et al. 2006; Veldkamp et al. 2008). Soil-N cycling responses to the combination of land-use change and soil texture have not yet been explored in Southeast Asian lowland forest landscapes.

The aim of our study was to assess changes in soil mineral-N production (gross $\mathrm{N}$ mineralization and gross nitrification rates), as indices of soil $\mathrm{N}$ availability, and mineral $\mathrm{N}$ retention processes (microbial $\mathrm{N}$ immobilization and DNRA) with land-use change. Gross soil-N cycling processes were measured in lowland forest and secondary forest with regenerating rubber (hereafter, "jungle rubber") as reference land uses, and the converted land uses of monoculture rubber and oil palm plantations, all located in two texturally different lowland Acrisol soils in Sumatra, Indonesia. Our study is the first to our knowledge that investigates gross soil-N cycling processes with land-use change in Southeast Asian lowland tropics, while also taking into account soil textural effects. Our investigation also explores the response of soil-N cycling to agricultural management intensity - by comparing systems with no fertilizer or liming input (i.e., jungle rubber and rubber plantations) to those with higher fertilizer and liming inputs, i.e., the controversial biofuel crop, oil palm.

We hypothesized that 1) gross soil-N cycling rates in the reference land uses will be higher in the clay than the loam Acrisol soils, and 2) gross soil-N cycling rates will be higher in the reference land uses (forest and jungle rubber) compared to the unfertilized converted land use (rubber plantation) and will be intermediate in the fertilized converted land use (oil palm plantation). Here, we provide much-needed background information on gross soil-N cycling rates in the dwindling Southeast Asian lowland forests, and how their soil-N production and retention processes are influenced by land-use conversion. 


\subsection{Materials and Methods}

\section{Study Sites}

The study was carried out in Jambi Province, central Sumatra, Indonesia. Two landscapes, characterized by their dominant soil texture and type, were selected in the region. The loam Acrisol soil ( $1^{\circ} 55^{\prime} 40^{\prime \prime} \mathrm{S}, 103^{\circ} 15^{\prime} 33^{\prime \prime} \mathrm{E}$ and elevation of $70 \pm 4 \mathrm{~m}$ above sea level, asl) was located approximately $60 \mathrm{~km}$ south of Jambi city and the clay Acrisol soil (2 $2^{\circ} 0^{\prime} 57^{\prime \prime} \mathrm{S}, 102^{\circ} 45^{\prime} 12^{\prime \prime} \mathrm{E}$ and elevation of $75 \pm 4 \mathrm{~m}$ asl) was located approximately $110 \mathrm{~km}$ west of Jambi city (Fig. 1.2; pg. 19). Acrisol soils cover $49.9 \%$ of the land area in Sumatra and $34.2 \%$ in Indonesia (FAO et al. 2014). The mean annual temperature is $26.7 \pm 1.0^{\circ} \mathrm{C}$ and mean annual precipitation is $2235 \pm 385 \mathrm{~mm}$ [19912011; climate station at the Jambi Sultan Thaha airport of the Meteorological, Climatological and Geophysical Agency]. Total dissolved N deposition through rainfall ranged from $12.9 \pm 0.1$ to $16.4 \pm$ $2.6 \mathrm{~kg} \mathrm{~N} \mathrm{ha}^{-1} \mathrm{yr}^{-1}$ measured in 2013 (Kurniawan et al. unpublished data).

\section{Experimental and Sampling Design}

In each soil landscape, four land-use systems were examined: mixed Dipterocarp (Kotowska et al. 2015) lowland forest and forest with regenerating rubber trees or jungle rubber, both as reference land uses, and smallholder monoculture plantations of rubber and oil palm. We consider the forest and jungle rubber as reference, for the baseline conditions that we compared to the converted smallholder plantations, for these reasons: 1) the rubber and oil palm plantations were established after logging, clearing and burning (see Management Practices in Smallholder Rubber and Oil Palm Plantations below) of either forests or jungle rubber (Euler et al. unpublished data), and 2) the jungle rubber sites were closer to the monoculture plantations than the forest sites, most of which were located $\geq 10 \mathrm{~km}$ from the plantation sites (Fig. 1.2). Trees in the monoculture plantations ranged from 7-17 years old, and tree species diversity, tree density, tree height and basal area (Kotowska et al. 2015) were greater in the reference land uses (forest and jungle rubber) than in the converted land uses (rubber and oil palm plantations) (S2.1 Table).

The space-for-time substitution approach, as used by Corre et al. (2007), was employed to determine the effects of land-use change on soil biochemical characteristics and soil-N cycling rates. An implicit assumption of this approach is that the initial soil characteristics were comparable prior to conversion. To test this assumption, we compared land-use independent soil characteristics (i.e. soil texture at deeper depths, $\geq 0.5 \mathrm{~m}$ ) among land uses within each landscape. Since we did not detect significant differences in soil texture between the reference land uses and the converted plantations within a soil landscape (S2.2 Table), we have assumed that the soil conditions were 
previously similar and that observed soil biochemical and soil- $\mathrm{N}$ cycling changes can be attributed to changes in land use.

For each land use in each landscape, four replicate plots were selected; each replicate plot was $50 \mathrm{~m}$ x $50 \mathrm{~m}$ with a minimum distance of $200 \mathrm{~m}$ between plots (Fig. 1.2; pg. 19). A $10 \mathrm{~m} \times 10 \mathrm{~m}$ grid was established across each plot, and we randomly selected ten grid points as subplots that were at least $5 \mathrm{~m}$ distance from the plot's border for soil sampling (Fig. 2.1). Soil samples were taken within an area of $0.4 \mathrm{~m} \times 0.4 \mathrm{~m}$ at each grid point, and were used to measure the general soil biochemical characteristics (see below). Soil characteristics for each replicate plot were represented by the average of the ten individual subplots. Soil sampling was conducted between June 2013 and December 2013. The soil had no organic layer but only a thin litter layer, and this was removed in order to sample predominantly mineral soil.

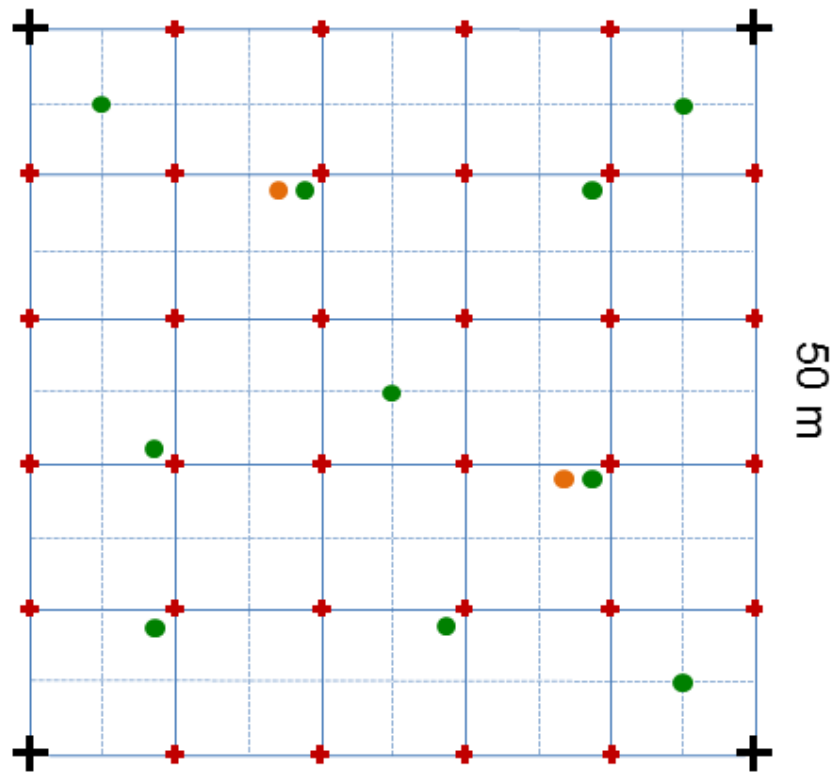

$50 \mathrm{~m}$

- Sampling point for soil-N cycling measurement

- Sampling point for soil biochemical analysis

+ Corners of $50 \mathrm{~m} \times 50 \mathrm{~m}$ plot flagged with permanent markers

+ Ten meter grid flagged with permanent markers

Figure 2.1. Sampling design in each of the four replicate plots (50 m x $50 \mathrm{~m}$ each) of the four land uses in the two soil landscapes (totaling 32 plots). Each plot had a $10 \mathrm{~m}$ x $10 \mathrm{~m}$ grid. Ten sampling points were selected for soil sampling for biochemical analysis (green dots) and two sampling points were selected for measuring gross soil-N cycling rates (orange dots). 
Soil samples were taken at various depth intervals down to $2 \mathrm{~m}$, and we report here the values from the top depth interval $(0-0.1 \mathrm{~m})$, except for clay percent, which we report for the top $0.5 \mathrm{~m}$ (Table 2.1) and depths $\geq 0.5 \mathrm{~m}$ (S2.2 Table). Soil samples were air dried and sieved ( $2 \mathrm{~mm}$ ) at the University of Jambi, Indonesia and sent to the Soil Science of Tropical and Subtropical Ecosystems (SSTSE) laboratory at Georg-August University Göttingen, Germany for analysis.

For soil-N cycling measurements, we randomly selected two subplots per plot that were at least $10 \mathrm{~m}$ from the plot's border (Fig. 2.1). Soil-N cycling rates for each plot were the average of the two individual subplots. Soil-N cycling measurements were conducted once in all land uses and were completed between January 2013 to May 2013 during the rainy season (see Gross Rates of Soil$N$ Cycling for more details).

\section{Management Practices in Smallholder Rubber and Oil Palm Plantations}

According to interviews with smallholders, conducted by Euler et al. (unpublished data), the rubber and oil palm plantations in the clay Acrisol soil were planted after clearing and burning the previous forest or logged forest. In the loam Acrisol soil, oil palm plantations were established after clearing and burning the previous jungle rubber whereas the rubber plantations were established from previously logged forest. Based on our interviews, only the oil palm plantations were fertilized during our study year, 2013, while the rubber plantations were not. Oil palm plantations in the clay Acrisol soil were fertilized once in the rainy season (October to March), and in the loam Acrisol soil, these were fertilized once in the rainy season and once in the dry season (April to September). The most commonly used fertilizers were NPK complete fertilizer (i.e., Phonska, Mahkota), potassium chloride $(\mathrm{KCl})$ and urea $\left(\mathrm{CO}\left(\mathrm{NH}_{2}\right)_{2}\right)$. Fertilizer additions to the oil palm plantations ranged from 300

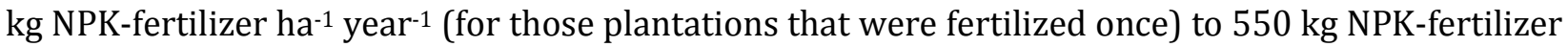
ha $^{-1}$ year-1 $^{-1}$ (for those plantations that were fertilized twice). In terms of unit nutrient element added, these rates were equivalent to 48-88 $\mathrm{kg} \mathrm{N}^{-1} \mathrm{year}^{-1}$, 21-38 $\mathrm{kg} \mathrm{P}^{\mathrm{P}} \mathrm{ha}^{-1}$ year-1 $^{-1}$ and 40-73 $\mathrm{kg} \mathrm{K} \mathrm{ha}^{-1}$

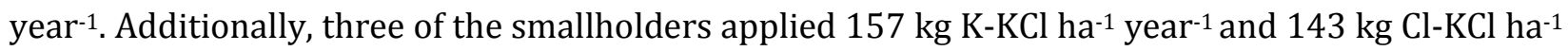

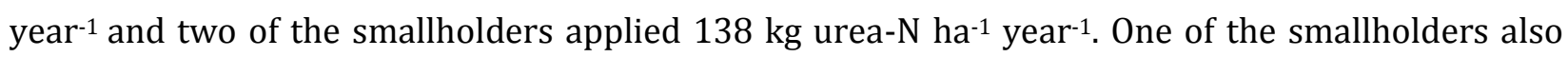
applied lime in 2013 at an average rate of $200 \mathrm{~kg}$ dolomite ha-1 year-1. Both manual and chemical weeding took place throughout the year at the rubber and oil palm plantations. The most commonly used herbicides were Gramoxone ${ }^{\circledR}$ and Roundup ${ }^{\circledR}$; these were applied at an average rate of 2 to $5 \mathrm{~L}$

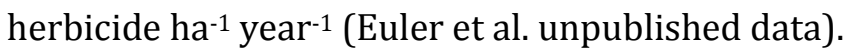




\section{Soil Characteristics}

The core method was used to measure soil bulk density for the top $0.5 \mathrm{~m}$ of soil depth (Blake and Hartge 1986). Soil $\mathrm{pH}\left(\mathrm{H}_{2} \mathrm{O}\right)$ was analyzed in a 1:4 soil-to-water ratio. Soil organic $\mathrm{C}$ and total $\mathrm{N}$ concentrations were analyzed from air-dried, sieved (2 mm) and ground samples using a CN analyzer (Vario EL Cube, Elementar Analysis Systems GmbH, Hanau, Germany). Air-dried and sieved soils were used to determine effective cation exchange capacity (ECEC) by percolating with unbuffered $1 \mathrm{~mol} \mathrm{~L}^{-1} \mathrm{NH}_{4} \mathrm{Cl}$ and cations (Ca, $\mathrm{Mg}, \mathrm{K}, \mathrm{Na}, \mathrm{Al}, \mathrm{Fe}$, and $\mathrm{Mn}$ ) were measured in percolates using an inductively coupled plasma-atomic emission spectrometer (iCAP 6300 Duo VIEW ICP Spectrometer, Thermo Fischer Scientific GmbH, Dreieich, Germany). Base saturation was calculated as percent exchangeable base cations of the ECEC. Extractable P was determined using the Bray 2 method, which is used for acidic tropical soils (Bray and Kurtz 1945). For ${ }^{15} \mathrm{~N}$ natural abundance signatures $\left(\delta^{15} \mathrm{~N}\right)$, the ten subsamples from each replicate plot were composited, ground and analyzed using isotope ratio mass spectrometry (IRMS; Delta Plus, Finnigan MAT, Bremen, Germany). Soil $\delta^{15} \mathrm{~N}$ has been linked to directly reflect soil $\mathrm{N}$ availability in that the larger the $\delta^{15} \mathrm{~N}$, the larger the gross rates of mineral N production (Arnold et al. 2009; Corre et al. 2010).

\section{Gross Rates of Soil-N Cycling}

The ${ }^{15} \mathrm{~N}$ pool dilution technique on intact soil cores was used to determine gross rates of soil-N cycling processes in the top $5 \mathrm{~cm}$ depth (Davidson et al. 1991). Within each replicate plot, we selected two grid points as subplots that were $20 \mathrm{~m}$ apart (Fig. 2), and in each subplot we took five intact soil cores (8 $\mathrm{cm}$ diameter and $5 \mathrm{~cm}$ length) near to each other. Gross soil-N cycling rates (i.e., gross $\mathrm{N}$ mineralization, gross nitrification, $\mathrm{N}$ immobilization and DNRA) were measured using four of the five soil cores, and background $\mathrm{NH}_{4}{ }^{+}$and $\mathrm{NO}_{3}{ }^{-}$levels and microbial biomass $\mathrm{C}$ and $\mathrm{N}$ were measured using one of the five soil cores, described in detail below.

In the field, two soil cores in each subplot were injected with $\left({ }^{15} \mathrm{NH}_{4}\right)_{2} \mathrm{SO}_{4}$ solution for measurement of gross $\mathrm{N}$ mineralization and $\mathrm{NH}_{4}+$ immobilization and the other two soil cores were injected with $\mathrm{K}^{15} \mathrm{NO}_{3}$ solution for gross nitrification, $\mathrm{NO}_{3}$ - immobilization and DNRA measurements. Using a side port needle, each intact soil core was injected with $5 \mathrm{~mL}$ of ${ }^{15} \mathrm{~N}$ solution containing 26 ug $\mathrm{N}-\mathrm{K}^{15} \mathrm{NO}_{3} \mathrm{~mL}^{-1}$ and 29 ug N-(15 $\left.\mathrm{NH}_{4}\right)_{2} \mathrm{SO}_{4} \mathrm{~mL}^{-1}$ both with $99 \%{ }^{15} \mathrm{~N}$ enrichment. The rates of ${ }^{15} \mathrm{~N}$ injection for both solutions ranged on average $1.4 \pm 0.1$ to $2.3 \pm 0.1 \mathrm{ug}{ }^{15} \mathrm{~N} \mathrm{~g}^{-1}$ across land uses and soil landscapes. One soil core of each ${ }^{15} \mathrm{~N}$-injected pair (one with ${ }^{15} \mathrm{NH}_{4}{ }^{+}$and one with ${ }^{15} \mathrm{NO}_{3}{ }^{-}$) was extracted with $0.5 \mathrm{~mol} \mathrm{~L}^{-1} \mathrm{~K}_{2} \mathrm{SO}_{4}$ approximately ten minutes after ${ }^{15} \mathrm{~N}$ injection $\left(\mathrm{T}_{0}\right.$ soil cores). Soil from the core was extruded, mixed well and large roots, stones and woody debris were removed. A subsample was put into a prepared bottle containing $150 \mathrm{~mL} 0.5 \mathrm{~mol} \mathrm{~L}^{-1} \mathrm{~K}_{2} \mathrm{SO}_{4}$ (with approximately 
1:3 ratio of fresh soil to $\mathrm{K}_{2} \mathrm{SO}_{4}$ solution). The remaining pair of ${ }^{15} \mathrm{NH}_{4}{ }^{+}$- and ${ }^{15} \mathrm{NO}_{3}$-injected soil cores were placed in a plastic bag and put back into the soil to incubate in-situ for one day ( $\mathrm{T}_{1}$ soil cores). The plastic bags were closed loosely to allow for air exchange, but prevent rain from entering and potentially leaching ${ }^{15} \mathrm{~N}$. $\mathrm{T}_{1}$ soil cores were extracted with $0.5 \mathrm{~mol} \mathrm{~L}^{-1} \mathrm{~K}_{2} \mathrm{SO}_{4}$ in the same way as the $\mathrm{T}_{0}$ soil cores. Part of the soil in each of the $\mathrm{T}_{1}$ cores was also fumigated with chloroform $\left(\mathrm{CHCl}_{3}\right)$ upon arrival in the laboratory (within maximally two hours from the field) for six days and then extracted with $0.5 \mathrm{~mol} \mathrm{~L}^{-1} \mathrm{~K}_{2} \mathrm{SO}_{4}$. These fumigated $\mathrm{T}_{1}$ cores were used for the determination of $\mathrm{NH}_{4}{ }^{+}$ and $\mathrm{NO}_{3}-$ immobilization. From each soil core, the remaining soil was oven-dried at $105{ }^{\circ} \mathrm{C}$ for at least one day to measure gravimetric moisture content, which was then used to calculate the dry mass of the extracted soil.

Upon arrival in the laboratory, soil extraction was continued by shaking the $\mathrm{K}_{2} \mathrm{SO}_{4}$ bottles with soil in a mechanical shaker for one hour. The extracts were filtered through pre-washed (with $0.5 \mathrm{~mol} \mathrm{~L}^{-1} \mathrm{~K}_{2} \mathrm{SO}_{4}$ ) filter papers ( $4 \mathrm{um}$ nominal pore size), and were frozen immediately. The frozen extracts were transported by air to Germany and remained frozen until further analysis at the SSTSE laboratory.

$\mathrm{NH}_{4}+$ and $\mathrm{NO}_{3}$ - concentrations in the extracts were determined by continuous flow injection colorimetry (SEAL Analytical AA3, SEAL Analytical GmbH, Norderstadt, Germany), using a salicylate and dicloroisocyanuric acid reaction for $\mathrm{NH}_{4}+$ determination (Autoanalyzer Method G-102-93) and the cadmium reduction method with $\mathrm{NH}_{4} \mathrm{Cl}$ buffer for $\mathrm{NO}_{3}-$ analysis (Autoanalyzer Method G-25402). ${ }^{15} \mathrm{~N}$ signatures in the $\mathrm{NH}_{4}{ }^{+}, \mathrm{NO}_{3}{ }^{-}$and extractable organic $\mathrm{N}$ pools in the extracts were determined by the diffusion method (for organic $\mathrm{N}$, after its conversion to $\mathrm{NO}_{3}$ - by persulfate digestion), following the same procedures as those outlined by Corre et al. $(2006 ; 2010)$, and ${ }^{15} \mathrm{~N}$ was determined using IRMS. Calculations of gross rates of soil-N cycling processes followed the calculation procedures given in detail by Davidson et al. (1991) and Silver et al. (2001).

From the fifth intact soil core taken at each subplot, initial levels of $\mathrm{NH}_{4}^{+}, \mathrm{NO}_{3}$, and soil microbial biomass $\mathrm{C}$ and $\mathrm{N}$ were determined. For $\mathrm{NH}_{4}{ }^{+}$and $\mathrm{NO}_{3}-$ levels, similar soil sample processing, in-situ $\mathrm{K}_{2} \mathrm{SO}_{4}$ extraction and laboratory analysis were used as above. For microbial biomass, the $\mathrm{CHCl}_{3}$ fumigation-extraction method was followed (Brooks et al. 1995; Davidson et al. 1989). A subsample of soil from a core was extracted immediately with $0.5 \mathrm{~mol} \mathrm{~L}^{-1} \mathrm{~K}_{2} \mathrm{SO}_{4}$ (unfumigated) and another subsample was fumigated with $\mathrm{CHCl}_{3}$ for six days and then extracted (fumigated) as described above. Organic $\mathrm{C}$ in the extracts was analyzed by UV-enhanced persulfate oxidation using a Total Organic Carbon Analyzer (TOC-Vwp, Shimadzu Europa GmbH, Duisburg, Germany) with an infrared detector. Organic $\mathrm{N}$ in the extracts was determined by ultravioletpersulfate digestion followed by hydrazine sulfate reduction using continuous flow injection 
colorimetry (Method G-157-96; SEAL Analytical AA3, SEAL Analytical GmbH, Norderstedt, Germany). Microbial biomass $\mathrm{C}$ and $\mathrm{N}$ were calculated as the difference in extractable organic $\mathrm{C}$ and $\mathrm{N}$ between the fumigated and unfumigated soils divided by $\mathrm{k}_{\mathrm{C}}=0.45$ and $\mathrm{k}_{\mathrm{N}}=0.68$ for a six-day fumigation period (Brooks et al. 1985).

\section{Statistical Analysis}

Statistical analysis was conducted on the means of the ten (soil biochemical characteristics) or two (soil-N cycling) subplots representing each replicate plot. Parameters that exhibited nonnormal distribution or heterogeneous variance (tested using Shapiro-Wilk and Levene's tests) were log transformed. First, we compared between the soil landscapes using the reference land uses to test our first hypothesis, and then among land uses for each soil landscape to test our second hypothesis. Linear mixed effects (LME) models were used with either landscape (i.e. comparing landscapes for each reference land use) or land use (i.e. comparing land uses for each landscape) as the fixed effect and replicate plots as the random effect. For assessing differences in soil-N cycling processes, the LME models included gravimetric moisture content as a covariate, because the measurements of these processes spanned four months (January-May 2013) across all 32 plots during which moisture content slightly varied between landscapes. Using soil moisture content, measured from the same soil cores as the soil-N cycling processes, as a covariate accounts for any masking effect of variation in soil moisture content across the measurement period on the differences among land uses. Fisher's least significant difference (LSD) test was used to assess significant differences among land uses. Differences were considered statistically significant at $\mathrm{P} \leq$ 0.05. For a few specified parameters, we also considered marginal significance at $P \leq 0.09$, because our experimental design encompassed the inherent spatial variability in our study area. To assess the relationships among soil-N cycling processes, we used Spearman's rank correlation tests among gross rates of soil- $\mathrm{N}$ cycling (i.e., gross $\mathrm{N}$ mineralization, gross nitrification, $\mathrm{N}$ immobilization and DNRA) and microbial (i.e., microbial biomass $\mathrm{C}$ and $\mathrm{N}$ ) parameters within a land use across landscapes. The same correlation test was conducted between gross rates of $\mathrm{N}$ mineralization as an index of soil $\mathrm{N}$ availability and soil biochemical characteristics across land uses for each landscape to assess how changes in soil biochemical characteristics due to land-use conversion relate to changes in soil N availability. We used R 3.0.3 for all statistical analyses (R Core Team 2014).

\section{Field-work Permission}

This study was a part of a DFG (German Research Foundation) funded project: Ecological and socio-economic functions of tropical lowland rainforest transformation systems (EEFForTs). 
EEFForTs is an interdisciplinary research project that investigates the effects of land-use change on environmental processes, biodiversity, and human dimensions and is a collaboration between Georg-August University Göttingen and several Indonesian universities. Indonesian management teams were established at the University of Jambi and Agricultural University of Bogor and were responsible for assistance in the procurement of all research and collection permits, as well as permissions from local land owners and managers of the agricultural sites for field sampling. This study was conducted using the research permits 215/SIP/FRP/SM/VI/2012 and 44/EXT/SIP/FRP/SM/V/2013 recommended by the Ministry of Research and Technology of the Republic of Indonesia (RISTEK). As well as, the collection permits 2703/IPH.1/KS.02/XI/2012 and S.13/KKH-2/2013 recommended by the Indonesian Institute of Sciences (LIPI) and issued by the Ministry of Forestry (PHKA). The lowland forest sites were located within protected areas managed by the PHKA and Restoration Ecosystem Indonesia Harapan (PT REKI). Indonesian research collaborators have also been involved in all stages from the conceptualization of the EEFForTs project, field design and sampling, sample exportation for analysis in Germany and finally in interpretation of results. The fieldwork did not involve sampling of endangered or protected species, and was predominantly soil sampling for nutrient element analysis.

\subsection{Results}

\section{Reference Land Uses: Forest and Jungle rubber}

The range of the average clay contents for the reference land uses in the loam Acrisol soil was lower than in the clay Acrisol soil (Table 2.1). In the forest sites, we did not detect significant differences between the two landscapes in most of the soil biochemical characteristics because of the large spatial variation among sites (e.g. variance components analysis showed that for the forest $32-77 \%$ of the variances of soil organic $\mathrm{C}$, total $\mathrm{N}, \mathrm{C}: \mathrm{N}$ ratio and ECEC were due to the variation among plots and only $0-11 \%$ were due to the variation between landscapes). This was primarily a result of the greater distance between the two sets of clay Acrisol forest plots (Fig. 1.2; pg. 19). However, a few clear differences between the two landscapes emerged: forest plots in the clay Acrisol soil had higher base saturation, extractable $\mathrm{P}$, exchangeable $\mathrm{Fe}$ and $\mathrm{Na}$ and lower $\mathrm{Al}$ saturation (61 $\pm 3 \%$ ) compared to those in the loam Acrisol soil ( $\mathrm{P} \leq 0.05$; Table 2.1; Al saturation for the loam Acrisol $80 \pm 1 \%$ ). In the jungle rubber, the differences in soil biochemical characteristics between landscapes were clearly shown. Soil pH, soil organic C stocks, total N stocks, ECEC and stocks of exchangeable base ( $\mathrm{Ca}, \mathrm{Mg}, \mathrm{K}$ and $\mathrm{Na}$ ) and acid ( $\mathrm{Al}, \mathrm{Fe}$ and $\mathrm{Mn}$ ) cations were higher in the clay than loam Acrisol soils ( $\mathrm{P} \leq 0.05$ to 0.09 ; Table 2.1). This was due to the lower spatial variation among jungle rubber sites, e.g. variance components analysis showed that only 8- 
$33 \%$ of the variances of soil organic $\mathrm{C}$, total $\mathrm{N}, \mathrm{C}: \mathrm{N}$ ratio and ECEC were due to the variation among plots.

The forest sites in the clay Acrisol soil had higher rates of $\mathrm{NH}_{4}+$ transformation processes (i.e. gross $\mathrm{N}$ mineralization and $\mathrm{NH}_{4}+$ immobilization) and microbial biomass $\mathrm{C}$ and $\mathrm{N}$ than those in the loam Acrisol soil ( $\mathrm{P} \leq 0.05$; Table 2.2). There were no significant differences in rates of $\mathrm{NO}_{3}{ }^{-}$ transformation processes detected between the two landscapes for these reference land uses ( $\mathrm{P} \geq$ 0.10); however, the rates of $\mathrm{NH}_{4}{ }^{+}$transformation processes were much higher in all land-use types in both landscapes compared to $\mathrm{NO}_{3}$ transformation processes (Table 2.2). Distinguishable attributes in the soil- $\mathrm{N}$ cycling between the reference land uses were that the $\mathrm{NO}_{3}^{-}$pool was higher in the forest than jungle rubber in both landscapes (both $\mathrm{P} \leq 0.05$ ) and the microbial C:N ratio was higher in the forest than jungle rubber in the clay Acrisol soil ( $\mathrm{P} \leq 0.09$; Table 2.2).

Positive correlations between gross $\mathrm{N}$ mineralization, $\mathrm{NH}_{4}{ }^{+}$immobilization and microbial biomass were also observed in both reference land uses (S2.3 Table). In the jungle rubber sites, gross $\mathrm{N}$ mineralization was positively correlated with $\mathrm{NH}_{4}{ }^{+}$and $\mathrm{NO}_{3}^{-}$- retention processes (i.e., immobilization and DNRA; S2.3 Table). 
Table 2.1. Soil characteristics (means $\pm \mathrm{SE}, \mathrm{n}=4$ ) in the top $0.1 \mathrm{~m}$ depth for different land-use types within each soil landscape in Jambi, Sumatra, Indonesia.

\begin{tabular}{|c|c|c|c|c|c|c|c|c|}
\hline \multirow[b]{2}{*}{ Characteristics } & \multicolumn{4}{|c|}{ loam Acrisol soil } & \multicolumn{4}{|c|}{ clay Acrisol soil } \\
\hline & $\begin{array}{l}\text { Lowland } \\
\text { forest }\end{array}$ & $\begin{array}{l}\text { Jungle } \\
\text { rubber }\end{array}$ & $\begin{array}{l}\text { Rubber } \\
\text { plantation }\end{array}$ & $\begin{array}{l}\text { Oil palm } \\
\text { plantation }\end{array}$ & $\begin{array}{l}\text { Lowland } \\
\text { forest }\end{array}$ & $\begin{array}{l}\text { Jungle } \\
\text { rubber }\end{array}$ & $\begin{array}{l}\text { Rubber } \\
\text { plantation }\end{array}$ & $\begin{array}{l}\text { Oil palm } \\
\text { plantation }\end{array}$ \\
\hline Clay $(\%)^{3}$ & $26.0 \pm 2.6$ & $30.6 \pm 4.6$ & $37.3 \pm 10.3$ & $33.4 \pm 2.2$ & $31.4 \pm 5.4$ & $47.2 \pm 12.4$ & $42.4 \pm 3.1$ & $59.7 \pm 5.2$ \\
\hline $\begin{array}{l}\text { Bulk density } \\
\left(\mathrm{g} \mathrm{cm}^{-3}\right)\end{array}$ & $1.0 \pm 0.0 \mathrm{ab}^{1}$ & $0.9 \pm 0.0 \mathrm{~b}$ & $1.1 \pm 0.1 \mathrm{a}$ & $1.1 \pm 0.1 \mathrm{a}$ & $1.0 \pm 0.1$ & $0.8 \pm 0.1$ & $0.9 \pm 0.1$ & $0.9 \pm 0.1$ \\
\hline pH $\left(1: 4 \mathrm{H}_{2} 0\right)$ & $4.3 \pm 0.04 \mathrm{~b}^{\dagger}$ & $4.3 \pm 0.03 \mathrm{~B}^{2} \mathrm{~b}^{\dagger}$ & $4.5 \pm 0.1 \mathrm{ab}^{\dagger}$ & $4.5 \pm 0.1 \mathrm{a}^{\dagger}$ & $4.2 \pm 0.0 \mathrm{~b}$ & $4.5 \pm 0.0 \mathrm{~A} \mathrm{a}$ & $4.5 \pm 0.1 \mathrm{a}$ & $4.4 \pm 0.0 \mathrm{a}$ \\
\hline $\begin{array}{l}\text { Soil organic C } \\
\left(\mathrm{kg} \mathrm{C} \mathrm{m}^{-2}\right)^{4}\end{array}$ & $2.6 \pm 0.2$ & $2.7 \pm 0.3 \mathrm{~B}$ & $2.0 \pm 0.3$ & $1.8 \pm 0.2$ & $3.3 \pm 0.5$ & $4.3 \pm 0.4 \mathrm{~A}$ & $2.8 \pm 0.4$ & $3.5 \pm 0.2$ \\
\hline $\begin{array}{l}\text { Total N } \\
\left(\mathrm{g} \mathrm{N} \mathrm{m}^{-2}\right)^{4}\end{array}$ & $182.9 \pm 10.8$ & $186.1 \pm 11.0 \mathrm{~B}$ & $172.6 \pm 23.8$ & $145.0 \pm 13.5$ & $263.4 \pm 67.1$ & $331.4 \pm 34.1 \mathrm{~A}$ & $198.9 \pm 32.5$ & $260.2 \pm 22.6$ \\
\hline C:N ratio & $14.3 \pm 0.2 \mathrm{a}$ & $13.7 \pm 0.8 \mathrm{a}$ & $11.7 \pm 0.7 \mathrm{~b}$ & $12.5 \pm 0.5 \mathrm{ab}$ & $13.1 \pm 1.3$ & $13.0 \pm 0.3$ & $14.3 \pm 0.6$ & $13.5 \pm 0.2$ \\
\hline $\begin{array}{l}\text { ECEC } \\
\left(\mathrm{mmol}_{\mathrm{c}} \mathrm{kg}^{-1}\right)\end{array}$ & $44.8 \pm 5.0$ & $40.6 \pm 7.6 \mathrm{~B}$ & $46.0 \pm 5.4$ & $39.5 \pm 7.9$ & $94.3 \pm 40.8$ & $124.5 \pm 25.5 \mathrm{~A}$ & $71.3 \pm 22.3$ & $78.1 \pm 8.4$ \\
\hline $\begin{array}{l}\text { Base saturation } \\
(\%)\end{array}$ & $10.6 \pm 0.5 \mathrm{~B} \mathrm{~b}^{\dagger}$ & $16.0 \pm 2.2 \mathrm{ab}^{\dagger}$ & $21.1 \pm 7.5 \mathrm{ab}^{\dagger}$ & $27.9 \pm 5.4 \mathrm{a}^{\dagger}$ & $22.9 \pm 5.6 \mathrm{~A}$ & $23.2 \pm 5.8$ & $20.1 \pm 2.6$ & $37.5 \pm 7.1$ \\
\hline$\delta^{15} \mathbf{N}(0 / 00)$ & $4.3 \pm 0.2 \mathrm{~b}$ & $4.5 \pm 0.1 \mathrm{~b}$ & $5.0 \pm 0.4 \mathrm{ab}$ & $5.4 \pm 0.3 \mathrm{a}$ & $4.5 \pm 0.04$ & $4.0 \pm 0.3$ & $4.6 \pm 0.4$ & $5.2 \pm 0.4$ \\
\hline $\begin{array}{l}\text { Extractable P } \\
\left(\mathrm{g} \mathrm{P} \mathrm{m}^{-2}\right)^{4}\end{array}$ & $0.5 \pm 0.1 \mathrm{~B}$ & $0.7 \pm 0.1$ & $0.5 \pm 0.1$ & $0.8 \pm 0.1$ & $1.4 \pm 0.1 \mathrm{~A} \mathrm{ab}$ & $0.8 \pm 0.1 b c$ & $0.4 \pm 0.04 \mathrm{c}$ & $4.7 \pm 1.5 \mathrm{a}$ \\
\hline $\begin{array}{l}\text { Aluminum } \\
\left(\mathrm{g} \mathrm{Al} \mathrm{m}^{-2}\right)^{4}\end{array}$ & $33.1 \pm 3.5$ & $29.6 \pm 6.6 \mathrm{~B}$ & $30.7 \pm 4.3$ & $23.5 \pm 2.7$ & $50.9 \pm 22.7$ & $76.6 \pm 15.6 \mathrm{~A}$ & $47.2 \pm 17.6$ & $34.4 \pm 2.0$ \\
\hline $\begin{array}{l}\text { Calcium } \\
\left(\text { g Ca m}^{-2}\right)^{4}\end{array}$ & $5.5 \pm 2.0$ & $6.9 \pm 0.8 \mathrm{~B}^{\dagger}$ & $14.5 \pm 7.1$ & $18.5 \pm 7.4$ & $32.3 \pm 21.2$ & $33.3 \pm 10.9 \mathrm{~A}^{\dagger}$ & $14.7 \pm 2.8$ & $59.1 \pm 19.5$ \\
\hline Iron $\left(\mathrm{g} \mathrm{Fe} \mathrm{m}^{-2}\right)^{4}$ & $0.8 \pm 0.1 \mathrm{~B} \mathrm{a}$ & $0.3 \pm 0.02 \mathrm{~B} \mathrm{bc}$ & $0.3 \pm 0.1 \mathrm{c}$ & $0.5 \pm 0.02 \mathrm{ab}$ & $3.7 \pm 1.1 \mathrm{~A} \mathrm{a}$ & $3.0 \pm 0.4 \mathrm{~A} \mathrm{a}$ & $2.3 \pm 0.6 \mathrm{a}$ & $0.7 \pm 0.3 \mathrm{~b}$ \\
\hline $\begin{array}{l}\text { Magnesium } \\
\left(\mathrm{g} \mathrm{Mg} \mathrm{m}^{-2}\right)^{4}\end{array}$ & $1.8 \pm 0.1$ & $2.0 \pm 0.3 \mathrm{~B}$ & $3.4 \pm 1.4$ & $1.7 \pm 0.9$ & $7.3 \pm 3.9$ & $12.0 \pm 4.1 \mathrm{~A}$ & $4.0 \pm 0.9$ & $3.5 \pm 0.8$ \\
\hline $\begin{array}{l}\text { Manganese } \\
\left(\mathrm{g} \mathrm{Mn} \mathrm{m}^{-2}\right)^{4}\end{array}$ & $0.3 \pm 0.1$ & $0.4 \pm 0.2 \mathrm{~B}$ & $0.8 \pm 0.3$ & $0.5 \pm 0.2$ & $4.5 \pm 3.1$ & $2.5 \pm 0.7 \mathrm{~A}$ & $1.5 \pm 0.4$ & $3.4 \pm 1.3$ \\
\hline $\begin{array}{l}\text { Potassium } \\
\left(\mathrm{g} \mathrm{K} \mathrm{m}^{-2}\right)^{4}\end{array}$ & $3.3 \pm 0.3$ & $2.6 \pm 0.2 \mathrm{~B}$ & $3.4 \pm 0.8$ & $2.1 \pm 0.8$ & $9.4 \pm 3.9$ & $9.6 \pm 2.6 \mathrm{~A}$ & $4.2 \pm 1.1$ & $4.8 \pm 0.9$ \\
\hline $\begin{array}{l}\text { Sodium } \\
\left(\text { g Na m}^{-2}\right)^{4}\end{array}$ & $0.5 \pm 0.1 \mathrm{~B} \mathrm{c}$ & $1.5 \pm 0.2 \mathrm{~B} \mathrm{~b}$ & $1.4 \pm 0.1 \mathrm{~b}$ & $3.9 \pm 1.1 \mathrm{a}$ & $3.6 \pm 0.8 \mathrm{~A}$ & $4.2 \pm 0.2 \mathrm{~A}$ & $3.7 \pm 1.3$ & $1.9 \pm 1.3$ \\
\hline
\end{tabular}

${ }^{1}$ Within row means followed by different lower case letters indicate significant differences between land-use types within a soil landscape (LME model with Fisher's LSD test at $\mathrm{P} \leq 0.05$ and marginally significant at ${ }^{\dagger} \mathrm{P} \leq 0.09$ ).

${ }^{2}$ Within row means followed by different upper case letters indicate significant differences between soil landscapes within a reference land use (LME model with Fisher's LSD test at $\mathrm{P} \leq 0.05$ and marginally significant at $+\mathrm{P} \leq 0.09$ ).

${ }^{3}$ Depth-weighted average for intervals of 0-0.1 m, 0.1-0.3 $\mathrm{m}$ and $0.3-0.5 \mathrm{~m}$ with $\mathrm{n}=3$ replicate plots per land use.

${ }^{4}$ Element stocks expressed in $\mathrm{g} \mathrm{m}^{-2}$ were calculated as: concentrations $\left(\mathrm{g} \mathrm{kg}^{-1}\right) *$ average bulk density of the reference land uses in each soil landscape ( $\mathrm{g} \mathrm{cm}{ }^{-3}$ ) ${ }^{*}$ depth $(\mathrm{cm}) * 10000 \mathrm{~cm}^{2} \mathrm{~m}^{-2} \div 1000 \mathrm{~g} \mathrm{~kg}^{-1}$. The average bulk density of the reference land uses is normally used in order to compare the same soil mass and avoid the interference of bulk density changes that often result from land-use changes due to management practices that compact or loosen the soil (de Blécourt et al. 2013). 
Table 2.2. Gross soil- $N$ cycling rates and pools (means $\pm S E, n=4$ ) in the top $0.5-m$ depth for different land-use types within each soil landscape in Jambi, Sumatra, Indonesia.

\begin{tabular}{|c|c|c|c|c|}
\hline & loam Acrisol soil & & & \\
\hline $\begin{array}{l}N \text { cycling rates or } \\
\text { pools }\end{array}$ & $\begin{array}{l}\text { Lowland } \\
\text { forest }\end{array}$ & $\begin{array}{l}\text { Jungle } \\
\text { rubber }\end{array}$ & $\begin{array}{l}\text { Rubber } \\
\text { plantation }\end{array}$ & $\begin{array}{l}\text { Oil palm } \\
\text { plantation }\end{array}$ \\
\hline $\begin{array}{l}\mathrm{NH}_{4}^{+} \\
\left(\mathrm{mg} \mathrm{N} \mathrm{kg-1)}^{-1}\right)\end{array}$ & $2.7 \pm 0.4 \mathrm{~B}^{\dagger 2}$ & $2.4 \pm 0.1$ & $2.7 \pm 0.3$ & $3.2 \pm 1.8$ \\
\hline $\begin{array}{l}\text { Gross N } \\
\text { mineralization } \\
\left(\text { mg N kg-1 }^{-1} \text { day }^{-1} \text { ) }\right.\end{array}$ & $5.4 \pm 0.7 \mathrm{~B}$ & $4.6 \pm 0.6$ & $6.2 \pm 0.7$ & $4.2 \pm 1.1$ \\
\hline $\begin{array}{l}\mathrm{NH}_{4}^{+} \\
\text {immobilization } \\
\left(\mathrm{mg} \mathrm{N} \mathrm{kg}^{-1} \text { day }^{-1}\right)\end{array}$ & $2.7 \pm 0.5 \mathrm{~B}$ & $4.0 \pm 1.0$ & $4.3 \pm 0.2$ & $1.9 \pm 0.4$ \\
\hline $\begin{array}{l}\mathrm{NO}_{3}^{-} \\
\left(\mathrm{mg} \mathrm{N} \mathrm{kg}^{-1}\right)\end{array}$ & $1.1 \pm 0.1 \mathrm{~B} \mathrm{a}^{1}$ & $0.4 \pm 0.3 \mathrm{bc}$ & $0.1 \pm 0.1 \mathrm{c}$ & $1.4 \pm 0.9 \mathrm{ab}$ \\
\hline $\begin{array}{l}\text { Gross nitrification } \\
\left.\text { (mg N kg-1 } \text { day }^{-1}\right)\end{array}$ & $1.9 \pm 0.4$ & $0.9 \pm 0.2$ & $0.9 \pm 0.2$ & $1.2 \pm 0.5$ \\
\hline $\begin{array}{l}\mathrm{NO}_{3}^{-} \text {immobilization } \\
\text { (mg N kg-1 } \text { day }^{-1} \text { ) }\end{array}$ & $0.9 \pm 0.4$ & $0.4 \pm 0.2$ & $0.7 \pm 0.3$ & $0.6 \pm 0.2$ \\
\hline $\begin{array}{l}\text { DNRA } \\
\text { (mg N kg-1 } \text { day }^{-1} \text { ) }\end{array}$ & $0.2 \pm 0.0 \mathrm{ab}$ & $0.2 \pm 0.0 \mathrm{~b}$ & $0.5 \pm 0.1 \mathrm{a}$ & $0.1 \pm 0.0 \mathrm{~b}$ \\
\hline $\begin{array}{l}\text { Microbial N } \\
\left(\mathrm{mg} \mathrm{N} \mathrm{kg}^{-1}\right)\end{array}$ & $69.7 \pm 4.8 \mathrm{~B}$ & $86.5 \pm 6.4$ & $73.8 \pm 10.9$ & $59.3 \pm 6.4$ \\
\hline $\begin{array}{l}\text { Microbial C } \\
\left(\mathrm{mg} \mathrm{C} \mathrm{kg-1)}^{-1}\right.\end{array}$ & $514.0 \pm 48.4 \mathrm{~B}$ & $577.7 \pm 45.1$ & $461.4 \pm 58.2$ & $403.1 \pm 23.5$ \\
\hline \multirow[t]{2}{*}{$\begin{array}{l}\text { Microbial biomass } \\
\text { C:N ratio }\end{array}$} & $7.2 \pm 0.3$ & $6.7 \pm 0.5$ & $6.3 \pm 0.4$ & $7.0 \pm 0.4$ \\
\hline & \multicolumn{4}{|l|}{ clay Acrisol soil } \\
\hline $\mathrm{NH}_{4}{ }^{+}\left(\mathrm{mg} \mathrm{N} \mathrm{kg}^{-1}\right)$ & $3.6 \pm 0.4 \mathrm{~A} \mathrm{ab}$ & $6.2 \pm 1.6 \mathrm{a}$ & $2.8 \pm 0.2 b$ & $4.3 \pm 1.0 \mathrm{ab}$ \\
\hline 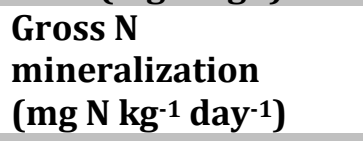 & $11.5 \pm 1.8 \mathrm{~A} \mathrm{a}^{\dagger}$ & $10.8 \pm 2.1 \mathrm{a}^{\dagger}$ & $6.0 \pm 0.6 \mathrm{~b}^{\dagger}$ & $9.3 \pm 2.1 \mathrm{ab}^{\dagger}$ \\
\hline $\begin{array}{l}\mathrm{NH}_{4}^{+} \\
\text {immobilization } \\
\left(\mathrm{mg} \mathrm{N} \mathrm{kg}^{-1} \text { day }^{-1}\right)\end{array}$ & $16.8 \pm 5.7 \mathrm{~A} \mathrm{a}$ & $14.8 \pm 2.9 \mathrm{a}$ & $5.5 \pm 1.2 \mathrm{ab}$ & $7.3 \pm 3.9 \mathrm{~b}$ \\
\hline $\mathrm{NO}_{3}^{-}\left(\mathrm{mg} \mathrm{N} \mathrm{kg}^{-1}\right)$ & $1.6 \pm 0.2 \mathrm{~A} \mathrm{a}$ & $0.2 \pm 0.1 \mathrm{bc}$ & $0.1 \pm 0.0 \mathrm{c}$ & $0.7 \pm 0.3 \mathrm{ab}$ \\
\hline $\begin{array}{l}\text { Gross nitrification } \\
\left(\mathrm{mg} \mathrm{N} \mathrm{kg}^{-1} \text { day }^{-1}\right)\end{array}$ & $0.9 \pm 0.3$ & $1.0 \pm 0.2$ & $0.7 \pm 0.2$ & $2.0 \pm 0.8$ \\
\hline $\begin{array}{l}\mathrm{NO}_{3}-\text { immobilization } \\
\left(\mathrm{mg} \mathrm{N} \mathrm{kg-1}^{-1} \text { day }^{-1}\right)\end{array}$ & $2.1 \pm 0.6$ & $3.3 \pm 0.6$ & $1.7 \pm 0.6$ & $1.7 \pm 0.4$ \\
\hline $\begin{array}{l}\text { DNRA }^{3} \\
\left(\mathrm{mg} \mathrm{N} \mathrm{kg-1}^{-1} \text { day }^{-1}\right)\end{array}$ & $0.4 \pm 0.2$ & $0.9 \pm 0.4$ & $0.5 \pm 0.1$ & $0.4 \pm 0.1$ \\
\hline $\begin{array}{l}\text { Microbial N } \\
\left(\mathrm{mg} \mathrm{N} \mathrm{kg}^{-1}\right)\end{array}$ & $134.4 \pm 27.6 \mathrm{~A} \mathrm{ab}$ & $152.8 \pm 28.0 \mathrm{a}$ & $75.4 \pm 6.6 \mathrm{c}$ & $104.6 \pm 23.4 \mathrm{bc}$ \\
\hline $\begin{array}{l}\text { Microbial C } \\
\left(\mathrm{mg} \mathrm{C} \mathrm{kg}^{-1}\right)\end{array}$ & $1048.1 \pm 200.8 \mathrm{~A} \mathrm{a}^{\dagger}$ & $922.3 \pm 222.5 \mathrm{ab}^{\dagger}$ & $560.7 \pm 60.7 \mathrm{c}^{\dagger}$ & $616.6 \pm 112.0 \mathrm{bc}^{\dagger}$ \\
\hline $\begin{array}{l}\text { Microbial biomass } \\
\text { C:N ratio }\end{array}$ & $7.9 \pm 0.5 \mathrm{a}^{\dagger}$ & $5.7 \pm 0.6 \mathrm{c}^{\dagger}$ & $7.5 \pm 0.6 \mathrm{ab}^{\dagger}$ & $6.1 \pm 0.4 \mathrm{bc}^{\dagger}$ \\
\hline
\end{tabular}

1Within row means followed by different lower case letters indicate significant difference between land-use types within a soil landscape (LME model with Fisher's LSD test at P $\leq 0.05$ and marginally significant at $\mathrm{P} \leq \mathrm{0.09}$ ).

${ }^{2}$ Within column means followed by different upper case letters indicate significant difference between soil landscapes within a reference land use (LME model with Fisher's LSD test at P $\leq$ 0.05 and marginally significant at $+P \leq 0.09$ ).

${ }^{3}$ Dissimilatory nitrate reduction to ammonium. 


\section{Converted Land Uses: Oil Palm and Rubber Plantations}

In both landscapes, soil $\mathrm{pH}$ was higher either in oil palm or rubber plantations compared to the reference land uses ( $\mathrm{P} \leq 0.05$ to 0.09 ; Table 2.1). Soil organic $\mathrm{C}$ and total $\mathrm{N}$ stocks tended to be lower in the oil palm and rubber plantations than jungle rubber (i.e., in clay Acrisol soil) or than both reference land uses (i.e., loam Acrisol soil) (Table 2.1), although these trends were not statistically significant $(\mathrm{P} \geq 0.10)$. The $\mathrm{C}: \mathrm{N}$ ratios were lower in the converted land uses than the reference land uses in the loam Acrisol soil ( $\mathrm{P} \leq 0.05$; Table 2.1). Base saturation and soil $\delta^{15} \mathrm{~N}$ signatures were higher in the oil palm plantations than the reference land uses in the loam Acrisol soil ( $\mathrm{P} \leq 0.05$ to 0.09; Table 2.1), and a similar trend was depicted in the clay Acrisol soil (Table 2.1) although not statistically significant $(\mathrm{P} \geq 0.10)$. Extractable $\mathrm{P}$ was highest in the oil palm plantations, in the clay Acrisol ( $\mathrm{P} \leq 0.05$; Table 2.1). Exchangeable Fe was lower in either oil palm or rubber plantations than the reference land uses in both landscapes $(\mathrm{P} \leq 0.05$; Table 2.1$)$ and exchangeable Al showed a similar trend but was not statistically significant $(P \geq 0.10)$. Na was higher in the oil palm plantations than the reference land uses in the loam Acrisol soil ( $\mathrm{P} \leq 0.05$; Table 2.1).

Gross $\mathrm{N}$ mineralization, $\mathrm{NH}_{4}{ }^{+}$immobilization and $\mathrm{NH}_{4}{ }^{+}$pools were lower in the converted land uses than the reference land uses in the clay Acrisol soil ( $\mathrm{P} \leq 0.05$ to 0.09; Table 2.2), whereas these $\mathrm{NH}_{4}{ }^{+}$transformation processes did not differ among land uses in the loam Acrisol soil (P $\geq$ 0.10). There were no differences in gross nitrification and $\mathrm{NO}_{3}$ - immobilization between converted and reference land uses in both landscapes (all $\mathrm{P} \geq 0.10$ ), but similar to that in the reference land uses the $\mathrm{NO}_{3}$ - transformation rates were smaller than the $\mathrm{NH}_{4}{ }^{+}$transformation rates in the converted land uses (Table 2.2). It was also noticeable that in the rubber plantations, and to a lesser extent the jungle rubber, the $\mathrm{NO}_{3}$ - pools were lower than those in the forests and oil palm plantations in both landscapes (both $\mathrm{P} \leq 0.05$; Table 2.2). With regards to $\mathrm{NO}_{3}$ - retention processes, DNRA was less important (had lower rates) than $\mathrm{NO}_{3}-$ immobilization across all land uses in both landscapes (Table 2.2). However, its proportion to gross nitrification was large (55\% to $71 \%$ ) in the rubber plantations that had the lowest gross nitrification and $\mathrm{NO}_{3}{ }^{-}$pools (Table 2.2). Microbial biomass $\mathrm{C}, \mathrm{N}$ and $\mathrm{C}: \mathrm{N}$ ratio did not differ (all $\mathrm{P} \geq 0.10$ ) between the converted and reference land uses in the loam Acrisol soil (Table 2.2), where microbial biomass was initially low (i.e., lower microbial $\mathrm{C}$ and $\mathrm{N}$ in the forest sites of loam than clay Acrisol soils). In the clay Acrisol soil, where the initial (or forests as reference land use) microbial biomass was large, microbial $\mathrm{C}$ and $\mathrm{N}$ were lower in the converted than reference land uses ( $\mathrm{P} \leq 0.05$ to 0.09 ; Table 2.2).

In the rubber plantations, gross $\mathrm{N}$ mineralization was correlated positively with gross nitrification, which, in turn, was correlated with $\mathrm{NO}_{3}$ - retention processes (immobilization and DNRA; S2.4 Table). In the oil palm plantations, gross N mineralization also correlated positively with 
$\mathrm{NH}_{4}{ }^{+}$immobilization and both as well as the $\mathrm{NO}_{3}-$ retention processes were directly correlated with either microbial C, $\mathrm{N}$ or both (S2.4 Table).

We investigated whether the changes in soil biochemical characteristics due to land-use conversion affect changes in soil $\mathrm{N}$ availability. In the loam Acrisol soil that had lower soil fertility than the clay Acrisol soil (i.e., Table 2.1: lower $\mathrm{pH}$, organic $\mathrm{C}$, total $\mathrm{N}, \mathrm{pH}$, ECEC, base saturation or stocks of exchangeable bases and extractable P; see Reference Land Uses above), there were no correlations detected between soil biochemical characteristics and the index of soil $\mathrm{N}$ availability (i.e., gross $\mathrm{N}$ mineralization) and microbial biomass across land-use types. However, in the clay Acrisol soil, gross $\mathrm{N}$ mineralization and microbial biomass $\mathrm{N}$ were positively correlated with soil organic $\mathrm{C}(\mathrm{R}=0.51, \mathrm{P} \leq 0.05, \mathrm{n}=16$ and $\mathrm{R}=0.62, \mathrm{P} \leq 0.05, \mathrm{n}=16$, respectively $)$, total $\mathrm{N}$ and ECEC and negatively correlated with soil C:N ratio (Fig. 2.2).

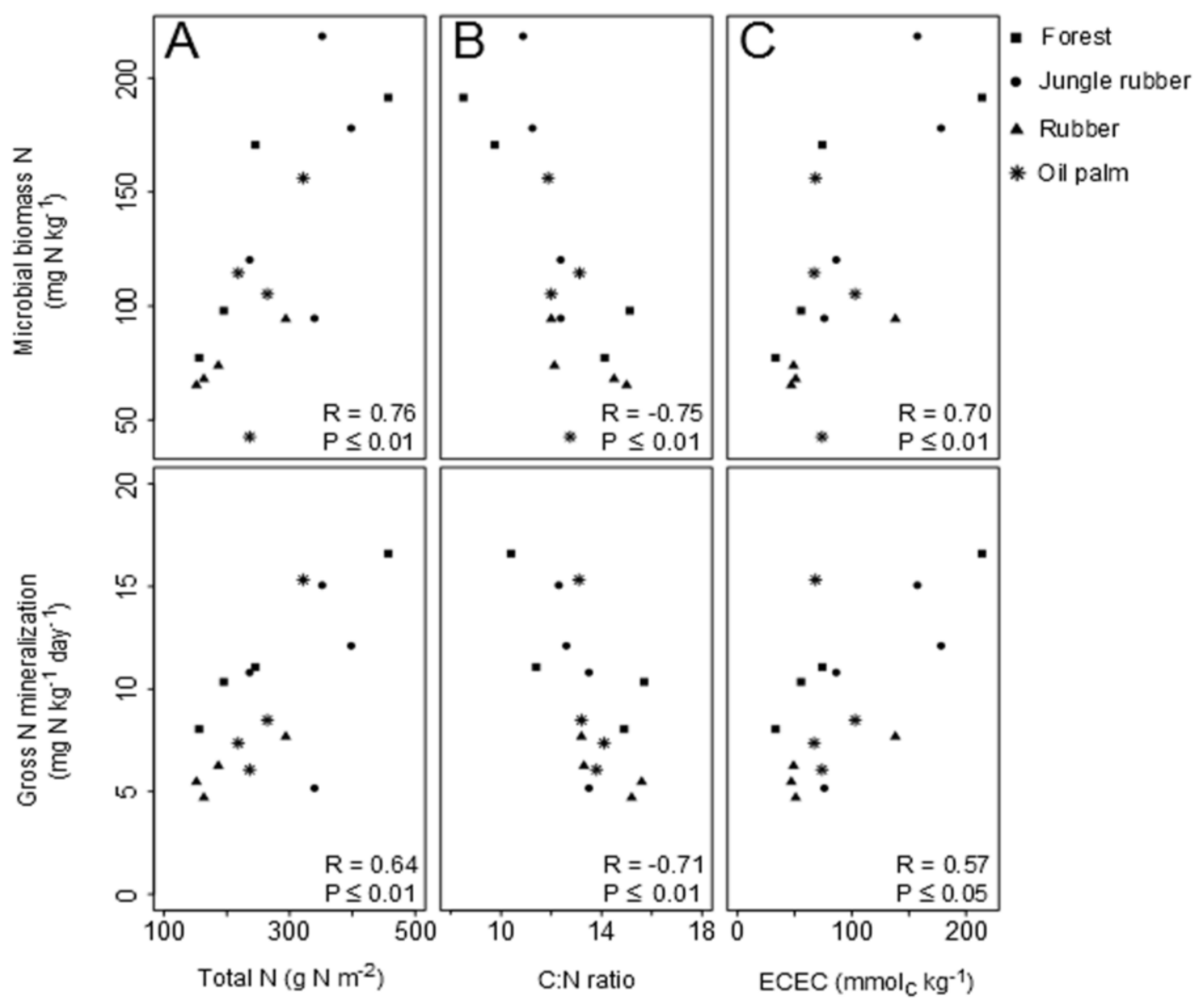

Figure 2.2. Relationships between microbial biomass $\mathrm{N}$ (top panels) and gross $\mathrm{N}$ mineralization (lower panels) with soil A) total N, B) C:N ratio and C) effective cation exchange capacity (ECEC) across land-use types within the clay Acrisol soil $(n=16)$ in Jambi, Sumatra, Indonesia, assessed using Spearman's rank correlations test. 


\subsection{Discussion}

\section{Soil-N Cycling in the Reference Land Uses}

The Acrisol soils in our reference land uses are characterized by low soil fertility (i.e., low ECEC and base saturation with conversely high Al saturation; Table 2.1) compared to other lowland forest soils on relatively less-weathered Cambisol and Nitisol soils (Corre et al. 2010). Within this Acrisol soil group, clay content influences soil fertility, as indicated by the better soil biochemical characteristics in the clay than the loam Acrisol in the reference land uses (i.e., Table 2.1: $\mathrm{pH}$, soil organic C, total N, extractable P, ECEC and base saturation or stocks of exchangeable bases). This corresponds with a study conducted across a textural gradient in lowland Amazonian forests on Ferralsol soils (which is a further weathered soil than our Acrisol soils) that found as clay content increases, C, N and ECEC also increases (Silver et al. 2000). We found that the clay Acrisol soil had ample substrate for microbial communities, evidenced by its higher organic $\mathrm{C}$ and total $\mathrm{N}$ stocks that were mirrored with larger microbial biomass, $\mathrm{NH}_{4}{ }^{+}$pool and $\mathrm{NH}_{4}{ }^{+}$transformation rates than the loam Acrisol soil (Table 2.2).

Studies of gross soil-N cycling rates in lowland tropical forests and agroforestry systems are limited, and the majority of these studies were conducted in Latin American forests. In terms of making comparisons, we limit these to studies conducted in lowland tropical soils that utilized the ${ }^{15} \mathrm{~N}$ pool dilution technique with in-situ incubation and extraction of mineral $\mathrm{N} . \mathrm{NH}_{4}{ }^{+}$ transformation rates in both reference land uses were comparable with those measured in a lowland forest in Costa Rica on Ferrasol soil (with gross $\mathrm{N}$ mineralization of $8 \pm 1 \mathrm{mg} \mathrm{N} \mathrm{kg}^{-1}$ day-1 $^{-1}$ (Silver et al. 2005)), but lower than those found in a lowland forest in Panama on more fertile Cambisol and Nitisol soils (with gross $\mathrm{N}$ mineralization of $29 \pm 6 \mathrm{mg} \mathrm{N} \mathrm{kg}^{-1}$ day$^{-1}$ (Corre et al. 2010)). $\mathrm{NO}_{3}$ - transformation rates were comparable to those measured in Panamanian lowland forest soils (with gross nitrification of $0.8 \pm 0.1 \mathrm{mg} \mathrm{N} \mathrm{kg}^{-1}$ day-1 $^{-1}$ (Corre et al. 2010)).

The dominance of $\mathrm{NH}_{4}{ }^{+}$pools and $\mathrm{NH}_{4}{ }^{+}$transformation rates in our reference land uses over $\mathrm{NO}_{3}{ }^{-}$pools and $\mathrm{NO}_{3}{ }^{-}$transformation rates (Table 2.2) indicates a largely $\mathrm{NH}_{4}{ }^{+}$based $\mathrm{N}$ economy, which is a common characteristic of the soil-N cycling in natural or unfertilized systems (Silver et al. 2001; Corre et al. 2006; Corre et al. 2010). The main difference between our reference land uses, in terms of labile $\mathrm{N}$ pools, was the larger microbial $\mathrm{C}: \mathrm{N}$ ratio and $\mathrm{NO}_{3}-$ pool in the forest than in the jungle rubber. A lower microbial C:N ratio typically indicates a bacterial dominated system (Corre et al. 2010), which may be a response to an increase in soil pH in the jungle rubber particularly in the clay Acrisol soil where microbial C: $\mathrm{N}$ ratio had also decreased (Table 2.2). Interestingly, the low $\mathrm{NO}_{3}{ }^{-}$ pool in jungle rubber, a feature that was much more distinct in the monoculture rubber plantations 
(see Soil-N Cycling in the Converted Land Uses below) is possibly due to the production of monoterpenes by rubber trees (Wang et al. 2007) that are known to reduce $\mathrm{NO}_{3}$ - levels and thus potentially alter soil N pathways (White 1991).

The correlation between gross $\mathrm{N}$ mineralization and $\mathrm{NH}_{4}+$ immobilization in the reference land uses (S2.3 Table) indicates tightly coupled $\mathrm{NH}_{4}{ }^{+}$transformation processes. The correlations of $\mathrm{NH}_{4}{ }^{+}$transformation rates with microbial $\mathrm{C}$ and $\mathrm{N}$ (S2.3 Table) also suggest the influence of microbial biomass size on such efficient internal soil-N cycling. Such tightly coupled N production and retention processes were enhanced in the jungle rubber, as suggested by the additional correlations with $\mathrm{NO}_{3}$ - immobilization and DNRA (S2.3 Table). This also supports the rapid conversion of $\mathrm{NO}_{3}$ - and hence possibly an even more efficient retention of $\mathrm{N}$ in this land-use type. In summary, the high gross $\mathrm{N}$ mineralization rates in these reference land uses, particularly in the clay Acrisol soil that had higher fertility relative to the loam Acrisol soil, are most likely linked to the high plant productivity (measured in the same reference land uses by Kotowska et al. (2015)) and nutrient returns to the soil through decomposition, as well as the presence of $\mathrm{N}$-fixing trees (e.g. S2.1 Table) that may have provided additional $\mathrm{N}$ to these systems (Corre et al. 2006; Sotta et al. 2008). Thus, forests or agroforestry systems with minimal management practices like our jungle rubber, on highly-weathered soils that have high clay content maintained a relatively sustainable availability of $\mathrm{N}$ through an efficient cycling within and between the soil and vegetation.

\section{Soil-N Cycling in the Converted Land Uses}

The changes in soil biochemical characteristics in the converted land uses, i.e., increases in $\mathrm{pH}$ (observed in both landscapes), base saturation, exchangeable $\mathrm{Na}$, soil $\delta^{15} \mathrm{~N}$ signatures and decrease in soil C:N ratio (all observed in loam Acrisol soil; Table 2.1), hinged on the legacy of biomass burning during conversion for both oil palm and rubber plantations and additionally by the influence of fertilization and liming for oil palm plantations. The effect of ashes (as source of inorganic nutrient ions) from biomass burning has been shown to remain decades after the initial burning (Markewitz et al. 2001) and our plantations were only 12-17 years old (S2.1 Table). A notable difference between the rubber and oil palm plantations was the extractable $\mathrm{P}$ (observed in the clay Acrisol soil; Table 2.1), which was highest in the fertilized oil palm plantations and lowest in the unfertilized rubber plantations. Al saturation in the clay Acrisol soil remained high in both rubber $(73 \pm 4 \%$ ) and oil palm plantations (53 $\pm 7 \%$; Table 2.1$)$. Our Acrisol soil is still within the Al buffering range (through Al solubilization at pH 3-5 (Van Breemen et al. 1983)), which may have resulted in a further decline in extractable $\mathrm{P}$ in the rubber plantations that had neither fertilization nor liming. Fertilization, liming and in part biomass burning may replenish nutrient stocks. 
However in unfertilized or non-agroforestry systems nutrient availability eventually declines within a decade of forest conversion as export from harvest and leaching exceeds the internal supply of nutrients in the soil (Dechert et al. 2004; Dechert et al. 2005; Corre et al. 2006; Veldkamp et al. 2008). We observed a trend of decreased (although statistically not detectable) soil organic $C$, total $\mathrm{N}$ and ECEC present in the oil palm or rubber plantations relative to either forest, jungle rubber or both (Table 2.1). Such decreases in soil biochemical characteristics corresponded with decreases in microbial $\mathrm{C}$ and $\mathrm{N}$ in the oil palm and rubber plantations (i.e., clay Acrisol soil; Table 2.1). These decreases in organic matter stocks in the converted land uses in the loam Acrisol soil were paralleled by a decrease in soil C:N ratio (Table 2.1). This suggests that the quality and quantity of organic matter input may have improved, making it more easily available for microbial use and vulnerable to losses. These losses are implied by the increased $\delta^{15} \mathrm{~N}$ signatures in the soil of the oil palm plantations (Table 2.1), which reflects increased $\mathrm{N}$ losses (i.e., leaching of $\mathrm{NH}_{4}{ }^{+}$and $\mathrm{NO}_{3}{ }^{-}$and emissions of $\mathrm{N}$-oxide gases increased following fertilization in oil palm sites; Kurniawan et al. unpublished data, Hassler et al. unpublished data) as isotopically light $\mathrm{N}$ is lost from the system leaving behind isotopically heavy soil N (Amundson et al. 2003). In summary, levels of exchangeable bases and extractable P were augmented in oil palm plantations mainly because of fertilization, whereas microbial biomass decreased in both converted land uses.

The decrease in microbial biomass in rubber and oil palm plantations in the clay Acrisol soil consequently affected soil- $\mathrm{N}$ cycling: gross $\mathrm{N}$ mineralization, $\mathrm{NH}_{4}{ }^{+}$immobilization and $\mathrm{NH}_{4}{ }^{+}$pools also decreased in these converted land uses (Table 2.2). Between the converted land uses in the clay Acrisol soil, where initial $\mathrm{NH}_{4}{ }^{+}$pools and $\mathrm{NH}_{4}{ }^{+}$transformation rates were large (i.e., reference forests; Table 2.2), these values were lowest in the unfertilized rubber plantations and intermediate in the fertilized oil palm plantations, thus supporting our second hypothesis. Fertilization in the oil palm plantations amended an otherwise eventual decrease in soil $\mathrm{N}$ availability in unfertilized systems (Corre et al. 2006). Soil microbial biomass and $\mathrm{NH}_{4}{ }^{+}$transformation rates in the converted land uses in the loam Acrisol soil were not as altered by land-use change as in the clay Acrisol soil, possibly because the microbial biomass and gross $\mathrm{NH}_{4}+$ transformation rates were initially low (i.e., reference forests; Table 2.2). We also found no correlations between the index of soil $\mathrm{N}$ availability with soil biochemical characteristics across land uses in the loam Acrisol soil, where soil fertility was lower than the clay Acrisol soil (Table 2.1). A similar pattern was observed from montane forest conversion in clay and sandy loam Cambisol soils in Sulawesi, Indonesia. The clay Cambisol soil that initially had large microbial biomass and gross $\mathrm{N}$ mineralization exhibits greater decreases upon conversion to unfertilized corn than the sandy loam Cambisol soil (Corre et al. 2006). These findings 
illustrate that larger initial microbial biomass pools and soil-N cycling rates, tend to promote larger potential reductions upon land-use conversion.

There are no previous data reported on gross soil-N cycling rates for oil palm and rubber plantations. Hence, we can only compare our values with previous studies based on management practices (i.e., fertilized vs. unfertilized systems) and age of converted sites. Our unfertilized rubber plantations had three times higher $\mathrm{NH}_{4}{ }^{+}$transformation rates than those found in unfertilized, 9year continuously cultivated corn on clay Cambisol soil in Sulawesi, Indonesia (Corre et al. 2006). $\mathrm{NH}_{4}{ }^{+}$transformation rates in our fertilized oil palm plantations were similar to the fertilized, 1-year tree plantation on sandy loam Ferralsol soil in Costa Rica (Silver et al 2005).

The rubber plantations, and to a lesser extent the jungle rubber, exhibited the lowest $\mathrm{NO}_{3}$ pools (Table 2.2), which is probably due to allelochemicals produced by rubber trees called monoterpenes. Previous research has shown that fluxes of monoterpenes from monoculture rubber plantations can be ten times greater than natural forest and that alpha- and beta-pinene, two commonly produced monoterpenes by rubber trees, reduce nitrification in soils (White 1991; Wang et al. 2007). The production of monoterpenes by rubber trees is believed to provide a $C$ source for soil microorganisms that increases their activity, and reduces $\mathrm{NO}_{3}$ - levels (White 1991), possibly via immobilization and DNRA as suggested by the correlations between gross nitrification, $\mathrm{NO}_{3}{ }^{-}$ immobilization and DNRA (S2.4 Table). This potentially conserves $\mathrm{N}$ in this land use where gross $\mathrm{N}$ mineralization was much reduced (i.e., clay Acrisol soil; Table 2.2).

The clay Acrisol soil that had initially high soil fertility (i.e., pH, soil organic C, total N, ECEC and base saturation or stocks of exchangeable bases in the reference land uses; Table 2.1), large microbial biomass and soil $\mathrm{N}$ availability (i.e., gross $\mathrm{N}$ mineralization in the reference land uses; Table 2.2) revealed that land-use change decreased soil fertility, subsequently decreasing microbial biomass and reduced soil $\mathrm{N}$ availability. This is evident by the correlations of gross $\mathrm{N}$ mineralization and microbial $\mathrm{N}$ with ECEC, total $\mathrm{N}$ and C:N ratio (Fig. 2.2), which depicts the forest (except two sites) and jungle rubber within the upper range, the fertilized oil palm within the middle range and the unfertilized rubber within the lower range of soil $\mathrm{N}$ availability. Exceptions were found in two of the forest and one of the jungle rubber sites that were somewhat within the lower range. This was most likely due to their further distances from the other set of sites and thus the considerable spatial variation for these reference land uses in this soil landscape (Fig. 1.2; pg. 18). Overall, the unfertilized rubber plantations exhibited the lowest fertility and microbial biomass (Fig. 2.2; Table 2.2). The soil-N cycle was predominantly linked with microbial biomass (S2.3 and S2.4 Tables), and without a robust microbial biomass pool, soil $\mathrm{N}$ availability in this land use decreased (i.e., lowest gross $\mathrm{N}$ mineralization; Table 2.2). The fertilized oil palm plantations showed slightly increased soil 
$\mathrm{N}$ availability along with increased soil biochemical characteristics (Fig. 2.2; Table 2.2), mainly due to management practices. However, the low microbial biomass in the oil palm plantations (Table 2.2) suggests that soil fertility and $\mathrm{N}$ availability were perhaps only temporarily abated by fertilization and may not be as sustainable as in the original reference land uses. In these Acrisol soils, which generally have low fertility relative to other less-weathered tropical soils, management practices in converted oil palm and rubber plantations should aim at maintaining the levels of microbial biomass as found in the original land use, because the availability of $\mathrm{N}$, and other nutrients, is dependent on its activity.

\subsection{Conclusions}

In these highly weathered Acrisol soils, clay content affects the inherent fertility of the reference land uses, corroborating our first hypothesis. Between the converted land uses, soil $\mathrm{N}$ availability and microbial biomass decreased in the unfertilized rubber plantations, and were intermediary in the fertilized oil palm plantations, supporting our second hypothesis. Although fertilization has been shown to hinder the decline in soil $\mathrm{N}$ availability and other nutrients in our oil palm plantations, $\mathrm{N}$ fertilization was also associated with negative impacts on groundwater quality and soil-atmosphere greenhouse gas exchange (Kurniawan et al. unpublished data; Hassler et al. unpublished data), as evident from the increased soil $\delta^{15} \mathrm{~N}$ signatures in the oil palm plantations. The typically low acid-buffering capacity of Acrisol soils makes them vulnerable to further decline in soil fertility with forest conversion to monoculture plantations, as evident by the decrease in extractable $\mathrm{P}$ in the unfertilized rubber plantations. Smallholders will likely become more dependent on fertilization and lime application in order to buffer the effects of additional acidity from $\mathrm{N}$ fertilization (Corre et al. 2010) and to enhance P availability in these Al saturated Acrisol soils that cover half of the land area of Sumatra. Overtime, $\mathrm{N}$ fertilization may lead to more negative impacts on soil fertility (i.e., further increases in Al solubility, base cation leaching losses and decreases in P solubility), surpassing fertilization's impact on soil $\mathrm{N}$ availability. The availability of soil $\mathrm{N}$ and other nutrients in these oil palm plantations will rely heavily on fertilization and liming, which will incur additional costs to the smallholders, unless more sustainable management practices are employed. Further studies should test management trials on-site to screen for

practices that will yield optimum benefits (e.g. harvest and profit) with maximum nutrient retention efficiency (or less nutrient losses) in the soil. 


\section{Acknowledgements}

We thank the village leaders, local plot owners, PT Humusindo, PT REKI, PT Perkebunan Nusantara VI, and Bukit Duabelas National Park for granting us access and use of their properties. We also acknowledge the other members of project A05 (Hassler et al. unpublished data; Kurniawan et al. unpublished data) for soil trace gas emissions and nutrient leaching data, projects B04 (Kotowska et al. 2015) and B06 (Rembold et al. unpublished data) for providing vegetation data (S2.1 Table) and project C07 (Euler et al. unpublished data) for land-use history and management practices. We are especially grateful to our Indonesian field and laboratory assistants, Fahrurrozy Borland and Khairul Anwar (University of Jambi), as well as the rangers within the protected forest areas for their assistance and guidance during field sampling. We also thank Dodo Gunawan from the Meteorological, Climatological and Geophysical Agency of Indonesia for the climate data, and Andrea Bauer, Kerstin Langs and Martina Knaust (Georg-August University Göttingen, Germany) for their assistance with laboratory analyses. 


\section{References}

Amundson R, Austin AT, Schuur AG, Yoo K, Matzek V, Kendall C, Uebersax, A, et al. Global patterns of the isotopic composition of soil and plant nitrogen. Global Biogeochem Cy. 2003; doi. 10.1029/2002GB001903.

Arnold J, Corre MD, Veldkamp E. Soil N cycling in old-growth forests across an Andosol toposequence in Ecuador. For Ecol Manage. 2009; 257: 2079-2087.

Blake GR, Hartge KH. Bulk density. In: Klute A, editor. Methods of soil analysis part 1, physical and mineralogical methods. Madison, WI: Soil Science Society of America; 1986. pp. 363-375.

de Blécourt M, Brumme R, Xu J, Corre MD, Veldkamp E. Soil carbon stocks decrease following conversion of secondary forests to rubber (Hevea brasiliensis) plantations. PLoS ONE. 2013; doi.10.1371/journal.pone.0069357.

Bray RH, Kurtz LT. Determination of total, organic, and available forms of phosphorus in soils. Soil Sci. 1945; 59: 39-45.

Brooks PC, Landman A, Pruden G, Jenkinson DS. Chloroform fumigation and the release of soil nitrogen: a rapid direct extraction method to measure microbial biomass nitrogen in soil. Soil Biol Biochem. 1985; 17: 837-842.

Carlson KM, Curran LM, Asner GP, McDonald Pittman A, Trigg SM, Adeney JM. Carbon emissions from forest conversion by Kalimantan oil palm plantations. Nat Clim Chang. 2012; doi: 10.1038/NCLIMATE1702.

Corre MD, Beese FO, Brumme R. Soil nitrogen cycle in high nitrogen deposition forest: changes under nitrogen saturation and liming. Ecol Appl. 2003; 13: 287-298.

Corre MD, Dechert G, Veldkamp E. Soil nitrogen cycling following montane forest conversion in Central Sulawesi, Indonesia. Soil Sci Soc Am J. 2006; 70: 359-366.

Corre MD, Brumme R, Veldkamp E, Beese FO. Changes in nitrogen cycling and retention processes in soils under spruce forests along a nitrogen enrichment gradient in Germany. Glob Change Biol. 2007; 13: 1509-1527.

Corre MD, Veldkamp E, Arnold J, Wright SJ. Impact of elevated N input on soil N cycling and losses in old-growth lowland and montane forests in Panama. Ecology. 2010; 91: 1715-1729.

Danielsen F, Beukema H, Burgess ND, Parish F, Brühl CA, Donald, PF, et al. Biofuel plantations on forested lands: double jeopardy for biodiversity and climate. Conserv Bio. 2008; 23: 348-358.

Davidson EA, Eckert RW, Hart SC, Firestone MK. Direct extraction of microbial biomass nitrogen from forest and grassland soils of California. Soil Biol Biochem. 1989; 21: 773-778. 
Davidson EA, Hart SC, Shanks CA, Firestone MK. Measuring gross nitrogen mineralization, immobilization, and nitrification by ${ }^{15} \mathrm{~N}$ isotopic pool dilution in intact soil cores. J Soil Sci. 1991; 42: 335-349.

Davidson EA, Matson PA, Vitousek PM, Riley R, Dunkin K, García-Méndez, G, et al. Processes regulating soil emissions of $\mathrm{NO}$ and $\mathrm{N}_{2} \mathrm{O}$ in a seasonally dry tropical forest. Ecology. 1993; 74: 130139.

Dechert G, Veldkamp E, Anas I. Is soil degradation unrelated to deforestation? Examining soil parameters of land use systems in upland Central Sulawesi, Indonesia. Plant Soil. 2004; 265: 197 209.

Dechert G, Veldkamp E, Brumme R. Are partial nutrient balances suitable to evaluate nutrient sustainability of land use systems? Results from a case study in Central Sulawesi, Indonesia. Nutr Cycl Agroecosys. 2005; 72: 201-212.

Food and Agricultural Organization. FAOSTAT. Available: http://faostat.fao.org/site/339/default.aspx. Accessed 5 November, 2014.

FAO, IIASA, ISRIC, ISSCAS and JRC. Harmonized World Soil Database (version 1.1). Available: http://www.fao.org/soils-portal/soil-survey/soil-maps-and-databases/harmonized-world-soildatabase-v12/en/. Accessed 8 December, 2014.

Fitzherbert EB, Struebig MJ, Morel A, Danielsen F, Brühl CA, Donald, PF, et al. How will oil palm expansion affect biodiversity? Trends Ecol Evol. 2008; 23: 538-545.

Gouyon A, de Foresta H, Levang P. Does 'jungle rubber' deserve its name? An analysis of rubber agroforestry systems in southeast Sumatra. Agrofor Syst. 1993; 22: 181-206.

Hall SJ, Matson PA. Nutrient status of tropical rain forests influences soil $\mathrm{N}$ dynamics after $\mathrm{N}$ additions. Ecol Monogr. 2003; 73: 107-129.

Hart SC, Nason GE, Myrold DD, Perry DA. Dynamics of gross nitrogen transformations in an oldgrowth forest: the carbon connection. Ecology. 1994; 75: 880-891.

Hedin LO, Brookshire ENJ, Menge DNL Barron AR. The nitrogen paradox in tropical forest ecosystems. Annu Rev Ecol Evol Syst. 2009; 40: 613-635.

Klinge R, Araujo Martins AR, Mackensen J, Fölster H. Element loss on rain forest conversion in East Amazonia: comparison of balances of stores and fluxes. Biogeochemistry. 2004; 69: 63-82.

Kotowska MM, Leuschner C, Triadiati T, Meriem S, Hertel D. Quantifying above- and belowground biomass carbon loss with forest conversion in tropical lowlands of Sumatra (Indonesia). Glob Change Bio. 2015; n/a-n/a. doi: 10.1111/gcb.12979.

Laumonier YL, Uryu Y, Stüwe M, Budiman A, Setiabudi B, Hadian O. Eco-floristic sectors and deforestation threats in Sumatra: identifying new conservation area network priorities for ecosystem-based land use planning. Biodivers Conserv. 2010; 19: 1153-1174. 
Margono BA, Potapov PV, Turubanova S, Stolle F, Hansen MC. Primary forest cover loss in Indonesia over 2000-2012. Nat Clim Chang. 2014; doi:10.1038/NCLIMATE2277.

Markewitz D, Davidson EA, Figueiredo RO, Victoria RL, Krusche AV. Control of cation concentrations in stream waters by surface soil processes in an Amazonian watershed. Nature. 2001; 410: 802-805.

Ngoze S, Riha S, Lehman J, Verchot L, Kinyangi J, Mbugua, D, et al. Nutrient constraints to tropical agroecosystem productivity in long-term degrading soils. Glob Change Biol. 2008; 14: 2810-2822.

R Core Team. R: A language and environment for statistical computing. R Foundation for Statistical Computing, Vienna, Austria. Available: http://www.R-project.org/. Accessed 1 June 2014.

Schuur EAG, Matson PA. Net primary productivity and nutrient cycling across a mesic to wet precipitation gradient in Hawaiian montane forest. Oecologia. 2001; 128: 431-442.

Silver WL, Neff J, McGroddy M, Veldkamp E, Keller M, Cosme R. Effects of soil texture on belowground carbon and nutrient storage in a lowland Amazonian forest ecosystem. Ecosystems. 2000; 3: 193-209.

Silver WL, Herman DJ, Firestone MK. Dissimilatory nitrate reduction to ammonium in upland tropical forest soils. Ecology. 2001; 82: 2410-2416.

Silver WL, Thompson AW, Reich A, Ewel JJ, Firestone MK. Nitrogen cycling in tropical plantation forests: potential controls on nitrogen retention. Ecol Appl. 2005; 15:1604-1614.

Sotta ED, Corre MD, Veldkamp E. Differing N status and N retention processes of soils under oldgrowth lowland forest in Eastern Amazonia, Caxiuanã, Brazil. Soil Biol Biochem. 2008; 40: 740-750.

Tanner EVJ, Vitousek PM, Cuevas E. Experimental investigation of nutrient limitation of forest growth on wet tropical mountains. Ecology. 1998; 79: 10-22.

Templer PH, Silver WL, Pett-Ridge J, DeAngelis KM, Firestone MK. Plant and microbial controls on nitrogen retention and loss in a humid tropical forest. Ecology. 2008; 89: 3030-3040.

Van Breemen N, Mulder J, Driscoll CT. Acidification and alkalinization of soils. Plant Soil. 1983; 75 : 283-308.

Veldkamp E, Purbopuspito J, Corre MD, Brumme R, Murdiyarso D. Land use change effects on trace gas fluxes in the forest margins of Central Sulawesi, Indonesia. J Geophys Res. 2008; doi:10.1029/2007JG000522.

Wang YF, Owen SM, Li QJ, Peñuelas J. Monoterpene emissions from rubber trees (Hevea brasiliensis) in a changing landscape and climate: chemical speciation and environmental control. Glob Change Biol. 2007; 13: 2270-2282.

White CS. The role of monoterpenes in soil nitrogen cycling processes in ponderosa pine: results from laboratory bioassays and field studies. Biogeochemistry. 1991; 12: 43-68. 


\section{Supplementary material}

S2.1 Table. Plantation age and mean \pm SE $(n=4)$ tree density, tree height, basal area, diameter at breast height (DBH) of trees $\geq 0.10 \mathrm{~m} \mathrm{DBH}$ and the most common tree species for each land-use type within each soil landscape in Jambi, Sumatra, Indonesia.

\begin{tabular}{|c|c|c|c|c|}
\hline & loam Acrisol soil & & & \\
\hline Characteristic & Lowland forest & Jungle rubber & $\begin{array}{l}\text { Rubber } \\
\text { plantation }\end{array}$ & $\begin{array}{l}\text { Oil palm } \\
\text { plantation }\end{array}$ \\
\hline $\begin{array}{l}\text { Age range } \\
\text { (years) }\end{array}$ & $\begin{array}{l}\text { not determined } \\
\text { (ND) }\end{array}$ & ND & $14-17$ & $12-16$ \\
\hline $\begin{array}{l}\text { Tree density } \\
\text { (trees ha-1) }^{1}\end{array}$ & $658 \pm 26$ & $525 \pm 60$ & $440 \pm 81$ & $140 \pm 4$ \\
\hline Tree height (m) ${ }^{1}$ & $20.0 \pm 0.6$ & $14.0 \pm 0.2$ & $13.4 \pm 0.5$ & $4.9 \pm 0.6$ \\
\hline $\begin{array}{l}\text { Basal area } \\
\left(\mathrm{m}^{2} \mathrm{ha}^{-1}\right)^{1}\end{array}$ & $30.7 \pm 1.0$ & $16.6 \pm 0.4$ & $12.2 \pm 1.6$ & $\begin{array}{l}\text { not applicable } \\
\text { (NA) }\end{array}$ \\
\hline DBH $(\mathrm{cm})^{1}$ & $21.0 \pm 0.5$ & $16.8 \pm 0.5$ & $17.8 \pm 1.2$ & NA \\
\hline \multirow[t]{3}{*}{$\begin{array}{l}\text { Most common tree } \\
\text { species }^{2}\end{array}$} & $\begin{array}{l}\text { Aporosa spp., } \\
\text { Burseraceae spp., } \\
\text { Dipterocarpaceae } \\
\text { spp., Fabaceae spp., } \\
\text { Gironniera spp., } \\
\text { Myrtaceae spp., } \\
\text { Plaquium spp., } \\
\text { Porterandia sp., } \\
\text { Shorea spp. }\end{array}$ & $\begin{array}{l}\text { Alstonia spp., } \\
\text { Artocarpus spp., } \\
\text { Fabaceae sp., } \\
\text { Hevea sp., } \\
\text { Macaranga spp., } \\
\text { Porterandia sp., } \\
\text { Sloetia sp. }\end{array}$ & $\begin{array}{l}\text { Hevea } \\
\text { brasiliensis }\end{array}$ & $\begin{array}{l}\text { Elaeis } \\
\text { guineensis }\end{array}$ \\
\hline & clay Acrisol soil & & & \\
\hline & Lowland forest & Jungle rubber & Rubber & Oil palm \\
\hline Age range (years) & ND & ND & $7-16$ & $9-13$ \\
\hline $\begin{array}{l}\text { Tree density } \\
\left(\text { trees ha-1) }^{1}\right.\end{array}$ & $471 \pm 31$ & $685 \pm 72$ & $497 \pm 15$ & $134 \pm 6$ \\
\hline Tree height (m) ${ }^{1}$ & $17.0 \pm 0.5$ & $15.2 \pm 0.3$ & $13.4 \pm 0.1$ & $4.0 \pm 0.3$ \\
\hline $\begin{array}{l}\text { Basal area } \\
\left(\mathrm{m}^{2} \mathbf{h a}^{-1}\right)^{1}\end{array}$ & $29.4 \pm 1.7$ & $21.1 \pm 1.4$ & $10.0 \pm 1.4$ & NA \\
\hline DBH $(\mathbf{c m})^{1}$ & $23.0 \pm 0.4$ & $17.3 \pm 0.6$ & $15.2 \pm 0.7$ & NA \\
\hline $\begin{array}{l}\text { Most common tree } \\
\text { species }^{2}\end{array}$ & $\begin{array}{l}\text { Archidendron sp., } \\
\text { Baccaurea spp., } \\
\text { Ochanostachys sp. }\end{array}$ & $\begin{array}{l}\text { Artocarpus spp., } \\
\text { Endospermum } \\
\text { sp., Hevea sp., } \\
\text { Macaranga spp. }\end{array}$ & $\begin{array}{l}\text { Hevea } \\
\text { brasiliensis }\end{array}$ & $\begin{array}{l}\text { Elaeis } \\
\text { guineensis }\end{array}$ \\
\hline
\end{tabular}

\footnotetext{
${ }^{1}$ Kotowska et al. 2015

${ }^{2}$ Rembold et al. (unpublished data), based on trees found in five subplots ( $5 \mathrm{~m} \times 5 \mathrm{~m}$ ) of each replicate plot $(50 \mathrm{~m} \times 50 \mathrm{~m}$ ) which had $\geq 20$ individuals, except Fabaceae spp. which had $\leq 20$ individuals.
} 
S2.2 Table. Soil clay contents (means $\pm S E, n=3$ ) in various depth intervals for different land- use types within each soil landscape in Jambi, Sumatra, Indonesia.

\begin{tabular}{lllll}
\hline & loam Acrisol soil & & \\
\hline Clay (\%) & Lowland forest & Jungle rubber & $\begin{array}{l}\text { Rubber } \\
\text { plantation }\end{array}$ & $\begin{array}{l}\text { Oil palm } \\
\text { plantation }\end{array}$ \\
\hline $\begin{array}{l}\mathbf{5 0 - 1 0 0 ~} \mathbf{~ c m} \\
\text { depth }\end{array}$ & $28.7 \pm 4.8$ & $38.8 \pm 9.0$ & $45.1 \pm 11.3$ & $41.0 \pm 3.1 \mathrm{~B}^{1}$ \\
$\begin{array}{l}\mathbf{1 0 0}-\mathbf{1 5 0} \mathbf{~ c m} \\
\text { depth }\end{array}$ & $33.3 \pm 7.6$ & $42.4 \pm 9.9$ & $46.1 \pm 9.9$ & $43.3 \pm 2.8 \mathrm{~B}$ \\
$\begin{array}{l}\mathbf{1 5 0}-\mathbf{2 0 0} \mathbf{~ c m} \\
\text { depth }\end{array}$ & $37.3 \pm 8.6$ & $44.5 \pm 10.0$ & $43.4 \pm 6.5$ & $47.6 \pm 4.5 \mathrm{~B}$ \\
& & & & \\
\hline
\end{tabular}

\begin{tabular}{lllll}
\hline & clay Acrisol soil & & \\
\hline & Lowland forest & Jungle rubber & $\begin{array}{l}\text { Rubber } \\
\text { plantation }\end{array}$ & $\begin{array}{l}\text { Oil palm } \\
\text { plantation }\end{array}$ \\
\hline $\begin{array}{l}\mathbf{5 0 - 1 0 0} \mathbf{~ c m} \\
\text { depth }\end{array}$ & $34.9 \pm 9.0 \mathrm{~b}^{\dagger 2}$ & $51.4 \pm 12.6 \mathrm{ab}^{\dagger}$ & $36.8 \pm 8.0 \mathrm{~b}^{\dagger}$ & $69.7 \pm 4.8 \mathrm{~A} \mathrm{~b}^{\dagger}$ \\
\hline $\begin{array}{l}\mathbf{1 0 0}-\mathbf{1 5 0} \mathbf{~ c m} \\
\text { depth }\end{array}$ & $39.0 \pm 13.0$ & $62.8 \pm 12.6$ & $40.8 \pm 10.3$ & $62.8 \pm 3.6 \mathrm{~A}$ \\
$\begin{array}{l}\mathbf{1 5 0}-\mathbf{2 0 0} \mathbf{~ c m} \\
\text { depth }\end{array}$ & $41.3 \pm 11.2$ & $46.6 \pm 16.2$ & $36.5 \pm 10.8$ & $63.3 \pm 6.1 \mathrm{~A}$ \\
\hline
\end{tabular}

${ }^{1}$ Within column means followed by different capital letters indicate significant differences between soil landscapes within a land-use type (LME model with Fisher's LSD test at P $\leq$ 0.05 and marginally significant at $+\mathrm{P} \leq 0.09$ ).

${ }^{2}$ Within row means followed by different lower case letters indicate significant differences between land-use types within a soil landscape (LME model with Fisher's LSD test at P $\leq$ 0.05 and marginally significant at $+\mathrm{P} \leq 0.09$ ). 
S2.3 Table. Spearman's rank correlation coefficients $(n=8)$ among gross rates of soil-N cycling and microbial biomass for the top $0.05 \mathrm{~m}$ depth for the reference land uses across both soil landscapes in Jambi, Sumatra, Indonesia.

\begin{tabular}{|c|c|c|c|c|c|c|c|}
\hline & $\begin{array}{l}\mathrm{NH}_{4}^{+} \\
\text {immobilization } \\
\left(\mathrm{mg} \mathrm{N} \mathrm{kg}^{-1} \text { day }^{-1}\right) \\
\end{array}$ & $\begin{array}{l}\text { Gross } \\
\text { nitrification } \\
\left(\mathrm{mg} \mathrm{N} \mathrm{kg}^{-1} \text { day }^{-1}\right) \\
\end{array}$ & $\begin{array}{l}\mathrm{NO}_{3}^{-} \\
\text {immobilization } \\
\left(\mathrm{mg} \mathrm{N} \mathrm{kg}^{-1} \text { day }^{-1}\right) \\
\end{array}$ & $\begin{array}{l}\text { DNRA' }^{1} \\
\left(\mathrm{mg} \mathrm{N} \mathrm{kg}^{-1} \text { day }^{-1}\right)\end{array}$ & $\begin{array}{l}\text { Microbial N } \\
\left(\mathrm{mg} \mathrm{N} \mathrm{kg}^{-1}\right)\end{array}$ & $\begin{array}{l}\text { Microbial C } \\
\left(\mathrm{mg} \mathrm{C} \mathrm{kg}^{-1}\right)\end{array}$ & $\begin{array}{l}\text { Microbial } \\
\text { C:N }\end{array}$ \\
\hline & Lowland forest & & & & & & \\
\hline $\begin{array}{l}\text { Gross } N \\
\text { mineralization } \\
\left(\mathrm{mg} \mathrm{N} \mathrm{kg}^{-1} \text { day }^{-1}\right)\end{array}$ & $0.83^{*}$ & -0.33 & 0.36 & 0.46 & $0.86^{*}$ & $0.81^{*}$ & 0.29 \\
\hline $\begin{array}{l}\mathrm{NH}_{4}+\text { immobilization } \\
\left(\mathrm{mg} \mathrm{N} \mathrm{kg}^{-1} \text { day }^{-1}\right)\end{array}$ & & -0.55 & 0.62 & 0.46 & $0.79 *$ & $0.74 *$ & 0.31 \\
\hline $\begin{array}{l}\text { Gross nitrification } \\
\left(\mathrm{mg} \mathrm{N} \mathrm{kg}^{-1} \text { day }^{-1}\right)\end{array}$ & & & -0.31 & -0.20 & -0.19 & -0.21 & -0.24 \\
\hline $\begin{array}{l}\mathrm{NO}_{3}^{-} \text {immobilization } \\
\left(\mathrm{mg} \mathrm{N} \mathrm{kg}^{-1} \text { day }^{-1}\right)\end{array}$ & & & & 0.57 & 0.55 & 0.64 & 0.45 \\
\hline $\begin{array}{l}\text { DNRA }^{1} \\
\left(\mathrm{mg} \mathrm{N} \mathrm{kg}^{-1} \text { day }^{-1}\right)\end{array}$ & & & & & 0.28 & 0.30 & -0.70 \\
\hline $\begin{array}{l}\text { Microbial N } \\
\left(\mathrm{mg} \mathrm{N} \mathrm{kg}^{-1}\right)\end{array}$ & & & & & & $0.98^{*}$ & $0.64^{\dagger}$ \\
\hline \multirow[t]{2}{*}{$\begin{array}{l}\text { Microbial C } \\
\left(\mathrm{mg} \mathrm{C} \mathrm{kg}^{-1}\right)\end{array}$} & & & & & & & $0.71^{*}$ \\
\hline & Jungle rubber & & & & & & \\
\hline 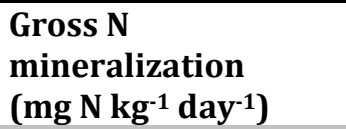 & $0.71^{*}$ & 0.00 & $0.74^{*}$ & $0.95^{*}$ & $0.76^{*}$ & $0.81^{*}$ & 0.41 \\
\hline $\begin{array}{l}\mathrm{NH}_{4}+\text { immobilization } \\
\left(\mathrm{mg} \mathrm{N} \mathrm{kg}^{-1} \text { day }^{-1}\right)\end{array}$ & & -0.05 & $0.98^{*}$ & $0.71^{*}$ & $0.81^{*}$ & 0.57 & -0.22 \\
\hline $\begin{array}{l}\text { Gross nitrification } \\
\left.\text { (mg N kg-1 } \text { day }^{-1}\right)\end{array}$ & & & 0.10 & -0.07 & 0.26 & -0.05 & -0.32 \\
\hline $\begin{array}{l}\mathrm{NO}_{3}^{-} \text {immobilization } \\
\text { (mg N kg-1 } \text { day }^{-1} \text { ) }\end{array}$ & & & & $0.76^{*}$ & $0.90^{*}$ & $0.64^{\dagger}$ & -0.17 \\
\hline $\begin{array}{l}\text { DNRA }^{1} \\
\left.\text { (mg N kg-1 } \text { day }^{-1}\right)\end{array}$ & & & & & $0.81^{*}$ & $0.88^{*}$ & 0.44 \\
\hline $\begin{array}{l}\text { Microbial N } \\
\left(\mathrm{mg} \mathrm{N} \mathrm{kg}^{-1}\right)\end{array}$ & & & & & & $0.83^{*}$ & -0.01 \\
\hline $\begin{array}{l}\text { Microbial C } \\
\left(\mathrm{mg} \mathrm{C} \mathrm{kg}^{-1}\right)\end{array}$ & & & & & & & 0.35 \\
\hline
\end{tabular}

${ }^{*} \mathrm{P} \leq 0.05$ and $+\mathrm{P} \leq 0.09$

${ }_{1}^{1}$ Dissimilatory nitrate reduction to ammonium. 
S2.4 Table. Spearman's rank correlation coefficients $(n=8)$ among gross rates of soil-N cycling and microbial biomass for the top $0.05 \mathrm{~m}$ depth for the converted land uses across both soil landscapes in Jambi, Sumatra, Indonesia.

\begin{tabular}{|c|c|c|c|c|c|c|c|}
\hline & $\begin{array}{l}\mathrm{NH}_{4}^{+} \\
\text {immobilization } \\
\left(\mathrm{mg} \mathrm{N} \mathrm{kg}^{-1} \text { day }^{-1}\right) \\
\end{array}$ & $\begin{array}{l}\text { Gross } \\
\text { nitrification } \\
\left(\mathrm{mg} \mathrm{N} \mathrm{kg}^{-1} \text { day }^{-1}\right) \\
\end{array}$ & $\begin{array}{l}\mathrm{NO}_{3}^{-} \\
\text {immobilization } \\
\left(\mathrm{mg} \mathrm{N} \mathrm{kg}^{-1} \text { day }^{-1}\right)\end{array}$ & $\begin{array}{l}\text { DNRA }^{1} \\
\text { (mg N kg-1 day- } \\
\text { 1) }\end{array}$ & $\begin{array}{l}\text { Microbial N } \\
\text { (mg N kg-1) }\end{array}$ & $\begin{array}{l}\text { Microbial C } \\
\left(\mathrm{mg} \mathrm{C} \mathrm{kg}^{-1}\right)\end{array}$ & $\begin{array}{l}\text { Microbial } \\
\text { C:N }\end{array}$ \\
\hline & \multicolumn{7}{|c|}{ Rubber plantation } \\
\hline 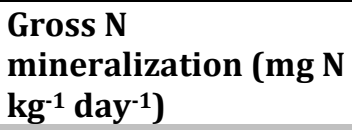 & 0.38 & $0.71^{*}$ & 0.57 & 0.64 & -0.24 & -0.33 & -0.10 \\
\hline $\begin{array}{l}\mathrm{NH}_{4}+\text { immobilization } \\
\left(\mathrm{mg} \mathrm{N} \mathrm{kg}^{-1} \text { day }^{-1} \text { ) }\right.\end{array}$ & & -0.17 & 0.50 & -0.19 & -0.19 & 0.21 & 0.52 \\
\hline $\begin{array}{l}\text { Gross nitrification } \\
\left(\mathrm{mg} \mathrm{N} \mathrm{kg}^{-1} \text { day }^{-1}\right)\end{array}$ & & & 0.55 & $0.93^{*}$ & 0.17 & -0.31 & -0.60 \\
\hline $\begin{array}{l}\mathrm{NO}_{3}-\text { immobilization } \\
\left(\mathrm{mg} \mathrm{N} \mathrm{kg}^{-1} \text { day }^{-1}\right)\end{array}$ & & & & $0.64^{\dagger}$ & 0.10 & 0.05 & -0.07 \\
\hline $\begin{array}{l}\text { DNRA' } \\
\text { (mg N kg-1 day-1) }\end{array}$ & & & & & 0.07 & -0.21 & -0.43 \\
\hline $\begin{array}{l}\text { Microbial N } \\
\left(\text { mg N kg-1) }^{-1}\right.\end{array}$ & & & & & & 0.62 & -0.29 \\
\hline \multirow{2}{*}{$\begin{array}{l}\text { Microbial C } \\
\left(\mathrm{mg} \mathrm{C} \mathrm{kg}^{-1}\right)\end{array}$} & & & & & & & 0.50 \\
\hline & \multicolumn{7}{|c|}{ Oil palm plantation } \\
\hline 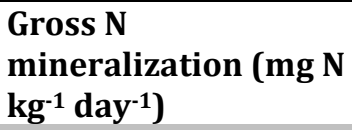 & $0.76^{*}$ & 0.43 & 0.48 & $0.63^{\dagger}$ & $0.67^{\dagger}$ & 0.62 & $-0.74^{*}$ \\
\hline $\begin{array}{l}\mathrm{NH}_{4}+\text { immobilization } \\
\left(\mathrm{mg} \mathrm{N} \mathrm{kg}^{-1} \text { day }^{-1}\right)\end{array}$ & & 0.55 & $0.88^{*}$ & $0.83^{*}$ & $0.86^{*}$ & $0.83^{*}$ & -0.60 \\
\hline $\begin{array}{l}\text { Gross nitrification } \\
\left(\mathrm{mg} \mathrm{N} \mathrm{kg}^{-1} \text { day }^{-1}\right)\end{array}$ & & & 0.62 & 0.17 & 0.52 & 0.38 & -0.33 \\
\hline $\begin{array}{l}\mathrm{NO}_{3}-\text { immobilization } \\
\left(\mathrm{mg} \mathrm{N} \mathrm{kg}^{-1} \text { day }^{-1}\right)\end{array}$ & & & & $0.71^{*}$ & $0.71^{*}$ & $0.67^{\dagger}$ & -0.36 \\
\hline $\begin{array}{l}\text { DNRA }^{1} \\
\left(\mathrm{mg} \mathrm{N} \mathrm{kg}^{-1} \text { day }^{-1}\right)\end{array}$ & & & & & 0.63 & $0.71^{*}$ & -0.42 \\
\hline $\begin{array}{l}\text { Microbial N } \\
\left(\mathrm{mg} \mathrm{N} \mathrm{kg}^{-1}\right)\end{array}$ & & & & & & $0.98 *$ & $-0.86^{*}$ \\
\hline $\begin{array}{l}\text { Microbial C } \\
\left(\mathrm{mg} \mathrm{C} \mathrm{kg}^{-1}\right)\end{array}$ & & & & & & & $-0.83^{*}$ \\
\hline
\end{tabular}

$* \mathrm{P} \leq 0.05$ and $+\mathrm{P} \leq 0.09$

1 Dissimilatory nitrate reduction to ammonium. 


\title{
Chapter 3
}

\section{Spatial variability surpasses land-use change effects on soil biochemical properties of converted lowland landscapes in Sumatra, Indonesia}

\author{
Kara Allen, Marife D. Corre, Syahrul Kurniawan, Sri Rahayu Utami and Edzo Veldkamp
}

\begin{abstract}
Deforestation rates in Sumatra, Indonesia are increasing rapidly due to global demand for palm oil and rubber. Forest conversion to agriculture decreases soil nutrient stocks overtime. However, inherent spatial variability in soil biochemical properties in converted landscapes could be high, and may supersede effects of land-use change on soil nutrient changes. Our aims were to assess changes in soil nutrient stocks down to $2 \mathrm{~m}$ depth with land-use change, and to quantify the proportions of spatial variability and land-use change effects on the overall variance of soil nutrient stocks. This study was conducted in Jambi Province, Sumatra, Indonesia in two distinct landscapes defined by the dominant soil texture and type: loam and clay Acrisol soils. In each landscape, four land-use types were examined: lowland forest and rubber interspersed in naturally regenerating forest (referred here as "jungle rubber") as reference land uses and smallholder plantations of rubber and oil palm. In the top $0.5 \mathrm{~m}$ depth, stocks of total $\mathrm{N}$, exchangeable $\mathrm{Al}, \mathrm{Ca}, \mathrm{Mg}, \mathrm{K}$ and extractable $\mathrm{P}$ as well as effective cation exchange capacity (ECEC) and base saturation were higher in the reference land uses in the clay than the loam Acrisol soils, illustrating that clay content influenced soil fertility in these highly weathered soils. Soil $\mathrm{pH}$, base saturation and extractable P stocks were higher in oil palm plantations than the reference land uses but only in the top $0.5 \mathrm{~m}$ depth; we attributed these to the legacy effect of biomass burning and fertilization in this converted land use. We were unable to detect significant effects of land-use change on other soil biochemical characteristics and nutrient stocks (i.e., ECEC, stocks exchangeable bases, soil organic carbon ( $\mathrm{SOC}$ ), total $\mathrm{N}$ ). Based on variance components analysis, a large proportion of the variance of these parameters was accounted by the variation amongst replicate plots (2691\%) rather than by land-use types (only 0-4\%). Power analysis showed that the optimum number of replicate plots to detect land-use change effects on these parameters ranged from 5-7. Our results suggest that spatial variability must be represented in the experimental design in order to detect land-use change effects on soil nutrient changes through stratifying the area of inference (i.e., landscape or region) based on known drivers of soil fertility and determining the optimal number of experimental units.
\end{abstract}




\subsection{Introduction}

Deforestation and the subsequent conversion to monoculture rubber (Hevea brasiliensis) and oil palm (Elaeis guineensis) plantations is occurring rapidly in tropical regions, especially in Southeast Asia. Lowland forests in Indonesia are increasingly being replaced by these economically important tree-cash crops. Previous studies have shown that the greenhouse gas balance-based on carbon (C) losses from oil palm in peat landscapes in Indonesia and Malaysia-incurs large C debts that can only be paid back after more than 400 years (Fargione et al., 2008). There are very few studies conducted in oil palm on mineral soils in Indonesia, even though mineral soils have far larger areal coverage than peat soils. Recent studies on aboveground C changes from forest conversion to oil palm plantations on highly weathered mineral soils in Jambi Province, Indonesia showed up to $151 \mathrm{Mg} \mathrm{C}^{-1} \mathrm{r}^{-1}$ reduction in aboveground biomass (Kotowska et al., 2015). From a pantropic study on highly weathered mineral soils (i.e., Acrisols and Ferralsols) that included Jambi Province, Indonesia, conversion of lowland forests to oil palm and rubber plantations decreases SOC stocks by $40 \%$ and $20 \%$ in the top $0.1 \mathrm{~m}$ depth (van Straaten et al., 2015), respectively, of which the latter is similar to what was found in tropical Yunnan Province, China (de Blécourt et al., 2013). However, none so far has included responses of mineral nutrients to these land-use changes in this particular region.

Information provided by the relatively few studies conducted in Indonesia illustrates that conversion of montane forests on less weathered, fertile soils to agricultural land uses in Central Sulawesi decreases soil fertility (Dechert et al., 2004). Conversion of lowland forests on highly weathered soils to rubber and oil palm plantations in Jambi Province increases soil pH, attributed primarily to the legacy effect of ashes from biomass burning during conversion, as well as soil $\mathrm{N}$ availability due to fertilization (Allen et al., 2015; van Straaten et al., 2015). However, fertilizer application in converted land-use systems mitigates only short-term nutrient shortage (Ngoze et al., 2008). The ultimate result with years of continuous cultivation after forest conversion is a decrease in soil nutrient levels and cycling (e.g., nitrogen; Corre et al., 2006; Davidson et al., 2007). Of the limited number of studies that focus on tropical land-use conversion and soil nutrient changes, most quantifications were restricted to the topsoil. A majority of previous studies quantified soil nutrient stocks and their changes within the top 0.3 or $0.4 \mathrm{~m}$ of soil (e.g., Dechert et al., 2004; Ngoze et al., 2008) although there are indications of SOC changes at soil depths $\geq 0.5 \mathrm{~m}$ (van Straaten et al., 2015; Veldkamp et al., 2003) and nutrient leaching losses at depths $\geq 1$ m (Dechert et al., 2005) with landuse conversion. 
At the landscape scale, soil texture is the main driver of spatial variation in soil fertility in highly weathered Ferralsol soils in the Brazilian Amazon (Silver et al., 2000; Sotta et al., 2008). Clay soils are known to have higher nutrient ion availability, higher water holding capacity and higher SOC stocks, total $\mathrm{N}$ stocks and soil-N cycling rates than coarser-textured soils. Thus, in our study region in Jambi, Indonesia, which is dominated by highly weathered Acrisol soils, it is important to consider the systematic spatial pattern of soil texture at a landscape scale when investigating the extent of nutrient changes from land-use conversion. A recent study conducted in the same lowland landscapes as our present study found that SOC stock losses from forest conversion to oil palm and rubber plantations are firstly hinged on the initial levels of SOC in the reference land use (i.e., forest) and secondly controlled by the clay contents of the soil (van Straaten et al., 2015). Forest soils with higher SOC are more susceptible to SOC losses while SOC stabilization is influenced by clay content.

On the other hand, land-use change effects on soil nutrient levels may be overshadowed by spatial variability. Since soil biochemical properties have inherently high spatial variability (Parkin, 1993; Pennock and Corre, 2001; Powers and Schlesinger, 2002), the spatial characterization (e.g., representing the spatial pattern within a landscape) and the number of soil samples taken to represent an experimental unit (i.e., replicate plot) are aspects that are often not addressed in quantifying changes in soil nutrient stocks due to land-use change. Recent studies on soil nutrient stocks and soil nutrient cycling in tropical forests conducted at the landscape scale based their experimental designs on the spatially-systematic occurrence of principal drivers of the measured processes (e.g., soil group or degree of soil development (de Koning et al., 2003; Hall and Matson, 2003), soil texture within a broad soil group (Silver et al., 2000; Sotta et al., 2008), topography within a landscape (Wolf et al., 2011), chronosequence (de Blécourt et al., 2013) or elevation gradient (Arnold et al., 2009; Baldos et al., 2015; Powers and Schlesinger, 2002)). These studies' experimental designs are often nested, similar to what we employed in our present study. Our study region is delineated into landscapes of distinct soil texture within a broad soil group; each landscape is represented by replicate plots which are randomly selected to represent each land-use type; and each replicate plot is represented by subplots that are randomly chosen for measurements of soil biochemical characteristics (Allen et al., 2015). Important advantages of a nested experimental design are not only to account the spatial driver (i.e., soil texture) on soil nutrients at the landscape scale, but also to quantify the variations accounted by the different spatial components of the experimental design (i.e., subplots, replicate plots, land uses and landscapes). 
Previous studies examining spatial patterns of SOC stocks have illustrated that SOC in tropical forests in southern China, Laos and Costa Rica is greatly influenced by small-scale variation, and that a majority of the overall variance on SOC stocks can be accounted by the spatial components within a landscape (i.e., elevation, Powers and Schlesinger, 2002; slope gradient, Chaplot et al., 2010; land-use age, de Blécourt, 2013). Additionally, examining soil nutrient stocks in a nested spatial design can be a useful tool in evaluating whether estimates can be extrapolated over large spatial areas (Powers and Schlesinger, 2002) or in relating environmental factors with ecosystem functioning and diversity. A recent study conducted in Jambi Province, Indonesia found that soil biochemical characteristics affect variability in litter macroinvertebrate beta-diversity and energy fluxes (Barnes, 2015). Thus, determining the spatial variability in soil nutrient stocks at the landscape scale may provide insight into variation in ecosystem diversity and functioning at the landscape scale.

The aims of this study were to 1) assess changes in soil nutrient stocks down to $2 \mathrm{~m}$ depth with land-use change and 2) determine the proportions of spatial variability and land-use change effects on the overall variance of soil nutrient contents. We measured soil biochemical characteristics and soil nutrient stocks in lowland forest and jungle rubber, as reference land uses, and in converted smallholder rubber and oil palm plantations, all located within two texturally different lowland Acrisol soils in Jambi Province, Sumatra, Indonesia. We hypothesized firstly that soil nutrient stocks in the reference land uses will be higher in the clay than the loam Acrisol soils, and secondly that if effects of land-use change are detectable, soil nutrient stocks will be highest in the reference land uses, lowest in the unfertilized converted land use (rubber) and intermediate in the fertilized converted land use (oil palm). Thirdly, we hypothesized that in cases where land-use change effects on soil biochemical characteristics are statistically not detectable, the proportions of the overall variance of soil biochemical characteristics will be highest between landscapes, followed by amongst replicate plots within landscapes and least by amongst subplots within replicate plots. In this study, we provide much-needed background information on soil nutrient contents down to 2 $m$ depth in the dwindling Indonesian lowland forests, and how they are influenced by land-use conversion as well as spatial variations of soil biochemical characteristics in commonly converted lowland landscapes. 


\subsection{Materials and Methods}

\section{Study Sites and Experimental Design}

Our study region in Jambi Province, Sumatra, Indonesia was delineated into two distinct lowland landscapes (Fig. 1.2; pg. 19), based on the dominant soil type and texture (i.e., clay Acrisol and loam Acrisol soils). The loam Acrisol soil landscape was located south of Jambi city ( $1^{\circ} 55^{\prime} 40^{\prime \prime} \mathrm{S}$, $103^{\circ} 15^{\prime} 33^{\prime \prime} \mathrm{E}$ and elevation of $70 \pm 4 \mathrm{~m}$ above sea level, asl) and the clay Acrisol soil landscape was located west of Jambi city $\left(2^{\circ} 0^{\prime} 57^{\prime \prime} \mathrm{S}, 102^{\circ} 45^{\prime} 12^{\prime \prime} \mathrm{E}\right.$ and elevation of $75 \pm 4 \mathrm{~m}$ asl; Fig. 1.2). The mean annual temperature in Jambi is $26.7 \pm 1.0^{\circ} \mathrm{C}$ and the mean annual precipitation is $2235 \pm 385$ mm (1991-2011; climate station at the Jambi Sultan Thaha airport of the Meteorological, Climatological and Geophysical Agency).

Four common land-use types were examined: mixed Dipterocarp (Kotowska et al., 2015) lowland forest and rubber interspersed in naturally regenerating secondary forest or jungle rubber as reference land uses, and smallholder monoculture plantations of rubber and oil palm (S2.1 Table; pg. 53). We considered the forest and jungle rubber as reference land uses, because the rubber and oil palm plantations were established on logged and/or burned forest or jungle rubber sites (Euler, 2015) and the jungle rubber sites were closer in proximity to the monoculture plantations compared to the forest sites (Fig. 1.2; pg. 19). In each landscape, four replicate plots per land-use type were selected $(\mathrm{n}=32)$ and each replicate plot was $50 \mathrm{~m} \times 50 \mathrm{~m}$ with a minimum distance of 200 $\mathrm{m}$ between plots (Fig. 1.2). Management practices in these smallholder monoculture plantations are described by Allen et al. (2015). In short, oil palm plantations represented typical smallholdermanaged land uses with fertilization (varying between 48-138 kg N ha-1 year-1, 21-38 kg P ha-1 year1 and 40-157 $\mathrm{K} \mathrm{ha}^{-1}$ year-1 $^{-1}$ with NPK complete and $\mathrm{KCl}$ fertilizers), liming (200 kg dolomite $\left(\mathrm{CaMg}\left(\mathrm{CO}_{3}\right)_{2}\right)$ ha $^{-1}$ year-1 ${ }^{-1}$ and weeding (herbicides) during our study period in 2013, whereas the rubber plantations represented the less managed land use having weeding but without any soil amendments during 2013. Prior to our study year, kieserite $\left(\mathrm{MgSO}_{4} \cdot \mathrm{H}_{2} \mathrm{O}\right)$ and borate $\left(\mathrm{Na}_{2} \mathrm{~B}_{4} \mathrm{O}_{2} .5 \mathrm{H}_{2} \mathrm{O}\right)$ fertilizers were also used in some oil palm plantations.

We employed the space-for-time substitution approach to determine the effects of land-use change on soil biochemical characteristics and soil nutrient stocks. To test if the initial soil conditions were comparable prior to conversion, we compared land-use independent soil characteristics (i.e., soil texture at deeper depths, $\geq 0.5 \mathrm{~m}$ ) as described by Allen et al. (2015). We did not detect significant differences in soil texture between the four land uses within each landscape (S2.2 Table; pg. 54). This, together with our interviews of the smallholders regarding previous land 
use, supports our assumption that the soil conditions were previously similar prior to conversion and that observed changes in soil biochemical characteristics and nutrient stocks can be attributed to land-use conversion.

\section{Soil Sampling}

Soil sampling was conducted in all 32 replicate plots between June 2013 and December 2013. The soil had no organic layer but only a thin litter layer, and this was removed in order to sample predominantly mineral soil from each land use. Within each $50 \mathrm{~m}$ x $50 \mathrm{~m}$ replicate plot, a 10 $\mathrm{m} \times 10 \mathrm{~m}$ grid was established and five grid points, that were at least $5 \mathrm{~m}$ distance from the plot's border, were randomly selected as subplots for point soil sampling. Soil samples were taken within an area of $0.4 \mathrm{~m} \times 0.4 \mathrm{~m}$ at each grid point, and were used to measure soil biochemical characteristics (i.e., soil $\mathrm{pH}, \mathrm{SOC}$, total $\mathrm{N}, \mathrm{C}: \mathrm{N}$ ratio, ECEC and base saturation) and soil nutrient stocks (i.e., exchangeable $\mathrm{Al}, \mathrm{Ca}, \mathrm{Fe}, \mathrm{K}, \mathrm{Mg}, \mathrm{Mn}, \mathrm{Na}$ and extractable $\mathrm{P}$ ). At each of the five randomly selected subplots, soil samples were collected at three depth intervals: 0-0.1 m, 0.1-0.3 m, 0.3-0.5 $\mathrm{m}$. The mean of the five subplots collected at each depth interval represented the value for each plot. Soil biochemical characteristics and nutrient stocks for the 0-0.5 $\mathrm{m}$ depth were calculated as cumulative stocks of the top three depth intervals, except for soil $\mathrm{pH}$, which was calculated using a depth-weighted average. At two of the five subplots ( $\geq 15 \mathrm{~m}$ apart from each other), soil samples were collected at a further three depth intervals: 0.5-1.0 m, 1.0-1.5 m and 1.5-2.0 m. Soil biochemical characteristics and nutrient stocks for the three deeper depths for each plot were represented by the mean of the two individual subplots.

Adjacent $(\geq 10 \mathrm{~m})$ to each of the replicate plots, a soil profile was dug to a depth of $2 \mathrm{~m}$. Two sets of intact soil cores, one to measure soil bulk density and one to measure soil texture, were vertically distributed at $0.05 \mathrm{~m}, 0.2 \mathrm{~m}, 0.4 \mathrm{~m}, 0.8 \mathrm{~m}, 1.3 \mathrm{~m}$, and $1.8 \mathrm{~m}$. Soil bulk density was measured from each plot $(n=32)$ and soil texture was measured from three of the four replicate plots per land use $(n=24)$. After collection, soil samples were air-dried and sieved ( $2 \mathrm{~mm}$ sieve) at the University of Jambi, Indonesia. Soil samples were transported by air to Georg-August University Göttingen, Germany and again dried at $40^{\circ} \mathrm{C}$ for three days prior to analysis.

\section{Laboratory analysis and calculations}

Soil $\mathrm{pH}$ was measured using a 1:4 soil-to-water ratio. Soil organic $\mathrm{C}$ and total $\mathrm{N}$ concentrations were analyzed from ground samples using a CN analyzer (Vario EL Cube, Elementar Analysis Systems GmbH, Hanau, Germany). The air-dried and sieved soil samples were used to determine ECEC by percolating with unbuffered $1 \mathrm{~mol} \mathrm{~L}^{-1} \mathrm{NH}_{4} \mathrm{Cl}$ and cations ( $\mathrm{Ca}, \mathrm{Mg}, \mathrm{K}, \mathrm{Na}, \mathrm{Al}, \mathrm{Fe}$, and $\mathrm{Mn}$ ) were measured in percolates using an inductively coupled plasma-atomic emission 
spectrometer (iCAP 6300 Duo VIEW ICP Spectrometer, Thermo Fischer Scientific GmbH, Dreieich, Germany). Base saturation was calculated as percent exchangeable base cations of the ECEC. Extractable P was determined using the Bray 2 method, which is used for acidic tropical soils (Bray and Kurtz, 1945). The core method (Blake and Hartge, 1986) was used to measure soil bulk density, and soil texture was measured using the pipette method (Gee and Bauder, 1986).

Element stocks were expressed in either $\mathrm{g} \mathrm{m}^{-2}$ or $\mathrm{kg} \mathrm{m}^{-2}$ (e.g., SOC) and were calculated as follows:

\section{Element stocks $\left(\mathrm{g} \mathrm{m}^{-2}\right)=E c\left(\mathrm{~g} \mathrm{~kg}^{-1}\right) * B D\left(\mathrm{~g} \mathrm{~cm}^{-3}\right) * \Delta D(\mathrm{~cm}) * 10000 \mathrm{~cm}^{2} \mathrm{~m}^{-2} \div 1000 \mathrm{~g} \mathrm{~kg}^{-1}$,}

where $E c$ is the element concentration, $B D$ is the average bulk density of the reference land use (i.e., forest) in each soil landscape and $\Delta D$ is the thickness of the sampling depth. The average bulk density of the reference land use (i.e., forest) is normally used in order to compare the same soil mass and avoid the interference of bulk density changes that often result from land-use changes due to management practices that compact or loosen the soil (de Blécourt et al., 2013; de Koning et al., 2003; van Straaten et al., 2015; Veldkamp, 1994).

\section{Statistical Analysis}

In order to test our first and second hypotheses, statistical tests on landscape effects and land-use effects were conducted separately for each sampling depth (i.e., 0-0.5 m, 0.5-1.0m, 1.0$1.5 \mathrm{~m}$ and $1.5-2.0 \mathrm{~m})$. For the first depth $(0-0.5 \mathrm{~m}$, which is the sum of the three depth intervals $0-$ $0.1 \mathrm{~m}, 0.1-0.3 \mathrm{~m}, 0.3-0.5 \mathrm{~m}$ ), each replicate plot was represented by the means of the five subplots. The plot values for the last three depth intervals $(0.5-1.0 \mathrm{~m}, 1.0-1.5 \mathrm{~m}$ and $1.5-2.0 \mathrm{~m})$ were represented by the mean of the two subplots. Parameters that exhibited non-normal distribution or heterogeneous variance (tested using Shapiro-Wilk's and Levene's tests) were log transformed. We compared between the two landscapes using the reference land uses (forest and jungle rubber) to test our first hypothesis. We then compared between land uses in each landscape to test our second hypothesis. Linear mixed effects (LME) models were used with either landscape (i.e., comparing landscapes for each reference land use) or land use (i.e., comparing land uses in each landscape) as the fixed effect and replicate plots as the random effect. Fisher's least significant difference (LSD) test was used to assess significant differences between the two landscapes or among the four land uses within each landscape. Differences were considered statistically significant at $\mathrm{P} \leq 0.05$. For a few specified parameters, we also considered marginal significance at $P \leq 0.09$, because our experimental design encompassed the inherent spatial variability in our study area. 
To test our third hypothesis, we used variance components analysis to partition the overall variance of each soil biochemical characteristic that is accounted by land-use types and by the spatial components (landscape, plots within landscape, and subplots within plot) of our nested experimental design. LME models were fitted as random intercepts with replicate plot nested within land-use type, which was then nested within landscape and subplot within replicate plot was represented by residual variation. The standard deviation of each component was squared and expressed as percentage of the total variance; this value represented the variation accounted by each component (Crawley, 2007). To determine the optimal number of replications per land-use type per landscape, an one-way ANOVA power analysis was conducted using the plot values (which are the means of the 5 subplots) of each soil biochemical characteristic (i.e., either SOC, total N, ECEC and stocks of exchangeable bases in the top $0.5 \mathrm{~m}$ ) in eight groups (4 land uses $\mathrm{x} 2$ landscapes). Sample sizes obtained from the power analysis represent the minimum number of replicate plots per group needed to detect significant differences between land-use types on the tested soil biochemical parameter with a known between-group variance, within-group variance, an $\alpha=0.05$ and a default power of $80 \%$ (Cohen, 1992; Crawley, 2007). All statistical analyses were conducted using R 3.0.3 (R Core Team, 2014).

\subsection{Results}

\section{Differences between landscapes based on reference land uses (i.e., forest and jungle rubber)}

The range of the average clay contents in the top $0.5 \mathrm{~m}$ soil depth of the reference land uses was lower in the loam than clay Acrisol soils (S2.2 Table; pg. 54). This trend was also prevalent at the deeper depths (0.5-2.0 m; S2.2 Table). We did not detect significant differences between the two landscapes of the forest sites in many of the soil biochemical characteristics (Table 3.1) and nutrient stocks (Table 3.2). This is due to the large spatial variation among forest plots (e.g., variance components analysis showed that for the forest $32-77 \%$ of the variances of soil organic $\mathrm{C}$, total $\mathrm{N}$, C:N ratio and ECEC were due to the variation among replicate plots and $0-11 \%$ were due to the variation between landscapes). A few clear differences between the two landscapes emerged: forest plots in the clay Acrisol soil had higher base saturation in each depth interval, higher extractable P, higher exchangeable Fe in the top $0.5 \mathrm{~m}$, and higher exchangeable $\mathrm{Ca}$ in $0.5-1.5 \mathrm{~m}$ than in the loam Acrisol soil ( $\mathrm{P} \leq 0.05$ to 0.09 ; Tables 3.1 and 3.2). Soil $\mathrm{pH}$ and exchangeable $\mathrm{Na}$ in the bottom depths $(1.0-2.0 \mathrm{~m})$ of the forest sites were higher in the loam than clay Acrisol soils $(\mathrm{P} \leq 0.05$ to 0.09 ; Tables 3.1 and 3.2). 
Differences in many soil biochemical characteristics (Table 3.1) and nutrient stocks (Table 3.2) between landscapes were clearer for the jungle rubber. In each depth interval, ECEC and exchangeable $\mathrm{Al}$ and Fe were higher in the clay than the loam Acrisol soils ( $\leq 0.05$ to 0.09; Tables 3.1 and 3.2). In the top depth (0-0.5 m) total $\mathrm{N}$ and exchangeable $\mathrm{Ca}, \mathrm{Mg}$ and $\mathrm{K}$ were higher in the clay than loam Acrisol soils ( $\mathrm{P} \leq 0.05$ to 0.09; Table 3.2) and in the lower depths (1.0-2.0 m) SOC and exchangeable $\mathrm{Ca}, \mathrm{Mg}, \mathrm{Mn}$ and $\mathrm{K}$ were higher in the clay than loam Acrisol soils ( $\mathrm{P} \leq 0.05$ to 0.09 ; Tables 3.1 and 3.2). Soil pH was higher in the loam than clay Acrisol soils at depths $0.5-1.0 \mathrm{~m}$ and 1.5-2.0 m (P $\leq$ 0.05; Table 3.1).

\section{Land-use change effects on soil biochemical characteristics}

Significant land-use change effects were not detected on a majority of the soil biochemical characteristics and soil nutrient stocks in both landscapes ( $\mathrm{P} \geq 0.10$; Tables 3.1 and 3.2). Soil pH was the only soil characteristic to exhibit significant land-use change effects at all depth intervals in each landscape. In the loam Acrisol soil, $\mathrm{pH}$ was highest in the jungle rubber and lowest in the forest in all depths compared with the converted land uses. In the clay Acrisol soil, $\mathrm{pH}$ was lowest in the forest and highest in the rubber and oil palm plantations in all depths ( $\mathrm{P} \leq 0.05$ to 0.09 ; Fig. 3.1a). Base saturation in the topsoil of both landscapes was higher in the oil palm plantations than the other land uses ( $\mathrm{P} \leq 0.09$; Fig. 3.1b) whereas base saturation in $0.5-1.0 \mathrm{~m}$ in the clay Acrisol soil was highest in the forest ( $\mathrm{P} \leq 0.05$ to 0.09; Fig. 3.1b). Exchangeable $\mathrm{Na}$ in the bottom depths $(1.0-2.0 \mathrm{~m})$ in the loam Acrisol soil was highest in the oil palm ( $\mathrm{P} \leq 0.05$; Fig. 3.1c). Extractable $\mathrm{P}$ in the topsoil (0-0.5 m) in the clay Acrisol soil was highest in the oil palm plantations ( $\mathrm{P} \leq 0.05$; Fig. $3.1 \mathrm{~d}$ ), while extractable $\mathrm{P}$ in the lower depths $(0.5-2.0 \mathrm{~m})$ in the clay Acrisol soil was lowest in rubber plantations ( $\mathrm{P} \leq 0.05$; Fig. 3.1d). 
Table 3.1. Soil biochemical characteristics (means $\pm S E, n=4$ ) for each land-use type at four depth intervals within each landscape in Jambi, Sumatra, Indonesia.

\begin{tabular}{|c|c|c|c|c|c|}
\hline \multicolumn{6}{|c|}{ loam Acrisol landscape } \\
\hline $\begin{array}{l}\text { Biochemical } \\
\text { characteristics }\end{array}$ & $\begin{array}{c}\text { Depth } \\
\text { (m) }\end{array}$ & $\begin{array}{l}\text { Lowland } \\
\text { forest }\end{array}$ & $\begin{array}{l}\text { Jungle } \\
\text { rubber }\end{array}$ & $\begin{array}{l}\text { Rubber } \\
\text { plantation }\end{array}$ & $\begin{array}{l}\text { Oil palm } \\
\text { plantation }\end{array}$ \\
\hline $\mathrm{pH}\left(1: 4 \mathrm{H}_{2} \mathrm{O}\right)$ & $\begin{array}{l}0-0.5 \\
0.5-1.0 \\
1.0-1.5 \\
1.5-2.0\end{array}$ & $\begin{array}{l}4.3 \pm 0.0 \mathrm{~b}^{1} \\
4.5 \pm 0.0 \mathrm{bc} \\
4.5 \pm 0.0 \mathrm{~A}^{2} \mathrm{~b} \\
4.5 \pm 0.0 \mathrm{~A} \mathrm{~b}\end{array}$ & $\begin{array}{l}4.6 \pm 0.0 \mathrm{a} \\
4.7 \pm 0.1 \mathrm{~A} \mathrm{a} \\
4.7 \pm 0.0 \mathrm{a} \\
4.8 \pm 0.1 \mathrm{~A} \mathrm{a}\end{array}$ & $\begin{array}{l}4.5 \pm 0.0 \mathrm{ab} \\
4.5 \pm 0.0 \mathrm{~b} \\
4.6 \pm 0.0 \mathrm{~b} \\
4.7 \pm 0.0 \mathrm{a}\end{array}$ & $\begin{array}{l}4.5 \pm 0.0 \mathrm{ab} \\
4.4 \pm 0.0 \mathrm{c} \\
4.5 \pm 0.0 \mathrm{~b} \\
4.6 \pm 0.1 \mathrm{ab}\end{array}$ \\
\hline $\begin{array}{l}\text { Soil organic C } \\
\left(\mathrm{kg} \mathrm{C} \mathrm{m}^{-2}\right)\end{array}$ & $\begin{array}{l}0-0.5 \\
0.5-1.0 \\
1.0-1.5 \\
1.5-2.0\end{array}$ & $\begin{array}{l}6.5 \pm 0.3 \\
4.1 \pm 0.4 \\
4.0 \pm 0.7 \\
2.9 \pm 1.1\end{array}$ & $\begin{array}{l}9.3 \pm 2.3 \\
4.4 \pm 0.9 \\
2.8 \pm 0.5 \mathrm{~B}^{\dagger} \\
1.8 \pm 0.3 \mathrm{~B}\end{array}$ & $\begin{array}{l}6.3 \pm 0.8 \\
4.8 \pm 1.0 \\
3.8 \pm 0.4 \\
2.0 \pm 0.3\end{array}$ & $\begin{array}{l}6.2 \pm 0.7 \\
3.3 \pm 0.5 \\
2.5 \pm 0.3 \\
1.7 \pm 0.1\end{array}$ \\
\hline $\begin{array}{l}\text { Total N } \\
\left(g^{-2} ~ m^{-2}\right)\end{array}$ & $\begin{array}{l}0-0.5 \\
0.5-1.0 \\
1.0-1.5 \\
1.5-2.0\end{array}$ & $\begin{array}{l}531.3 \pm 25.3 \\
432.9 \pm 39.6 \\
402.5 \pm 44.6 \\
333.3 \pm 50.2\end{array}$ & $\begin{array}{l}660.1 \pm 63.8 \mathrm{~B} \\
406.9 \pm 79.8 \\
316.1 \pm 70.9 \\
230.9 \pm 60.9\end{array}$ & $\begin{array}{l}600.4 \pm 63.4 \\
507.5 \pm 75.2 \\
436.1 \pm 31.5 \\
298.6 \pm 41.9\end{array}$ & $\begin{array}{l}511.1 \pm 48.7 \\
366.7 \pm 70.9 \\
333.2 \pm 62.8 \\
258.3 \pm 42.2\end{array}$ \\
\hline C:N ratio & $\begin{array}{l}0-0.5 \\
0.5-1.0 \\
1.0-1.5 \\
1.5-2.0\end{array}$ & $\begin{array}{l}36.0 \pm 0.5 \\
9.5 \pm 0.3 \\
9.5 \pm 0.6 \\
8.4 \pm 0.6\end{array}$ & $\begin{array}{l}38.4 \pm 3.5 \\
10.7 \pm 0.7 \\
9.3 \pm 1.0 \\
8.3 \pm 1.6\end{array}$ & $\begin{array}{l}31.7 \pm 2.0 \\
9.3 \pm 0.9 \\
8.7 \pm 0.5 \\
6.8 \pm 0.9\end{array}$ & $\begin{array}{l}36.6 \pm 2.4 \\
9.1 \pm 1.0 \\
7.9 \pm 0.8 \\
7.1 \pm 0.9\end{array}$ \\
\hline $\begin{array}{l}\text { ECEC }^{3} \\
\left(\mathrm{mmol}_{\mathrm{c}} \mathrm{kg}^{-1}\right)\end{array}$ & $\begin{array}{l}0-0.5 \\
0.5-1.0 \\
1.0-1.5 \\
1.5-2.0\end{array}$ & $\begin{array}{l}135.0 \pm 13.5 \\
56.7 \pm 6.7 \\
67.7 \pm 12.6 \\
83.6 \pm 25.0\end{array}$ & $\begin{array}{l}113.7 \pm 30.7 \mathrm{~B} \\
35.0 \pm 12.6 \mathrm{~B} \\
39.8 \pm 16.9 \mathrm{~B} \\
42.3 \pm 21.2 \mathrm{~B}\end{array}$ & $\begin{array}{l}125.2 \pm 19.3 \\
56.7 \pm 7.9 \\
51.9 \pm 7.1 \\
62.7 \pm 13.7\end{array}$ & $\begin{array}{l}120.9 \pm 30.1 \\
44.3 \pm 14.7 \\
45.1 \pm 17.0 \\
49.4 \pm 17.4\end{array}$ \\
\hline $\begin{array}{l}\text { Base saturation } \\
(\%)\end{array}$ & $\begin{array}{l}0-0.5 \\
0.5-1.0 \\
1.0-1.5 \\
1.5-2.0\end{array}$ & $\begin{array}{l}27.3 \pm 4.1 \mathrm{~B}^{\dagger} \mathrm{b}^{\dagger} \\
3.9 \pm 0.6 \mathrm{~B} \\
3.9 \pm 0.5 \mathrm{~B} \\
4.6 \pm 0.8 \mathrm{~B}^{\dagger}\end{array}$ & $\begin{array}{l}32.5 \pm 6.2 \mathrm{~b}^{\dagger} \\
7.4 \pm 1.9 \\
7.1 \pm 1.6 \\
12.6 \pm 5.5\end{array}$ & $\begin{array}{l}35.2 \pm 6.4 \mathrm{ab}^{\dagger} \\
6.8 \pm 1.1 \\
4.7 \pm 0.6 \\
5.3 \pm 0.8\end{array}$ & $\begin{array}{l}51.8 \pm 6.9 \mathrm{a}^{\dagger} \\
8.9 \pm 2.4 \\
6.4 \pm 1.1 \\
12.6 \pm 5.2\end{array}$ \\
\hline \multicolumn{6}{|c|}{ clay Acrisol landscape } \\
\hline $\begin{array}{l}\text { Biochemical } \\
\text { characteristics }\end{array}$ & $\begin{array}{c}\text { Depth } \\
\text { (m) }\end{array}$ & $\begin{array}{l}\text { Lowland } \\
\text { forest }\end{array}$ & $\begin{array}{l}\text { Jungle } \\
\text { rubber }\end{array}$ & $\begin{array}{l}\text { Rubber } \\
\text { plantation }\end{array}$ & $\begin{array}{l}\text { Oil palm } \\
\text { plantation }\end{array}$ \\
\hline $\mathrm{pH}\left(1: 4 \mathrm{H}_{2} \mathrm{O}\right)$ & $\begin{array}{l}0-0.5 \\
0.5-1.0 \\
1.0-1.5 \\
1.5-2.0\end{array}$ & $\begin{array}{l}4.2 \pm 0.0 \mathrm{~b} \\
4.4 \pm 0.0 \mathrm{~b}^{\dagger} \\
4.4 \pm 0.0 \mathrm{~B} \mathrm{~b} \\
4.4 \pm 0.0 \mathrm{~B} \mathrm{c}\end{array}$ & $\begin{array}{l}4.5 \pm 0.0 \mathrm{a} \\
4.5 \pm 0.0 \mathrm{~B} \mathrm{a}^{\dagger} \\
4.6 \pm 0.1 \mathrm{a} \\
4.5 \pm 0.0 \mathrm{~B} \mathrm{bc}\end{array}$ & $\begin{array}{l}4.5 \pm 0.1 \mathrm{a} \\
4.5 \pm 0.1 \mathrm{a}^{\dagger} \\
4.6 \pm 0.1 \mathrm{a} \\
4.6 \pm 0.1 \mathrm{ab}\end{array}$ & $\begin{array}{l}4.5 \pm 0.0 \mathrm{a} \\
4.6 \pm 0.1 \mathrm{a}^{\dagger} \\
4.6 \pm 0.0 \mathrm{a} \\
4.7 \pm 0.0 \mathrm{a}\end{array}$ \\
\hline $\begin{array}{l}\text { Soil organic C } \\
\left(\mathrm{kg} \mathrm{C} \mathrm{m}^{-2}\right)\end{array}$ & $\begin{array}{l}0-0.5 \\
0.5-1.0 \\
1.0-1.5 \\
1.5-2.0\end{array}$ & $\begin{array}{l}9.2 \pm 1.8 \\
6.0 \pm 1.2 \\
5.0 \pm 1.1 \\
4.1 \pm 0.7\end{array}$ & $\begin{array}{l}12.4 \pm 1.5 \\
6.0 \pm 1.0 \\
4.5 \pm 0.6 \mathrm{~A}^{\dagger} \\
3.6 \pm 0.7 \mathrm{~A}\end{array}$ & $\begin{array}{l}8.7 \pm 1.8 \\
5.1 \pm 1.0 \\
4.6 \pm 0.7 \\
3.9 \pm 0.7\end{array}$ & $\begin{array}{l}10.1 \pm 1.0 \\
4.7 \pm 0.4 \\
3.9 \pm 0.4 \\
3.1 \pm 0.5\end{array}$ \\
\hline $\begin{array}{l}\text { Total N } \\
\left(g^{\prime} ~ m^{-2}\right)\end{array}$ & $\begin{array}{l}0-0.5 \\
0.5-1.0 \\
1.0-1.5 \\
1.5-2.0\end{array}$ & $\begin{array}{l}820.9 \pm 263.8 \\
580.9 \pm 194.4 \\
501.7 \pm 162.5 \\
456.9 \pm 143.0\end{array}$ & $\begin{array}{l}1074.2 \pm 158.8 \mathrm{~A} \\
619.8 \pm 110.2 \\
500.1 \pm 72.8 \\
450.8 \pm 98.2\end{array}$ & $\begin{array}{l}680.6 \pm 166.5 \\
485.2 \pm 129.6 \\
447.8 \pm 103.2 \\
398.5 \pm 95.4\end{array}$ & $\begin{array}{l}814.6 \pm 70.5 \\
455.0 \pm 43.7 \\
426.1 \pm 26.6 \\
334.8 \pm 58.4\end{array}$ \\
\hline C:N ratio & $\begin{array}{l}0-0.5 \\
0.5-1.0 \\
1.0-1.5 \\
1.5-2.0\end{array}$ & $\begin{array}{l}37.7 \pm 4.6 \\
11.6 \pm 1.3 \\
11.0 \pm 1.1 \\
9.9 \pm 1.2\end{array}$ & $\begin{array}{l}35.0 \pm 1.7 \\
9.7 \pm 0.3 \\
9.1 \pm 0.5 \\
8.0 \pm 0.4\end{array}$ & $\begin{array}{l}38.9 \pm 1.5 \\
10.9 \pm 0.6 \\
10.7 \pm 0.7 \\
10.2 \pm 0.8\end{array}$ & $\begin{array}{l}37.1 \pm 1.4 \\
10.5 \pm 0.8 \\
9.1 \pm 0.6 \\
9.4 \pm 0.9\end{array}$ \\
\hline $\begin{array}{l}\text { ECEC }^{3} \\
\left(\mathrm{mmol}_{\mathrm{c}} \mathrm{kg}^{-1}\right)\end{array}$ & $\begin{array}{l}0-0.5 \\
0.5-1.0 \\
1.0-1.5 \\
1.5-2.0\end{array}$ & $\begin{array}{l}253.5 \pm 134.5 \\
76.5 \pm 46.5 \\
92.3 \pm 59.8 \\
104.3 \pm 74.7\end{array}$ & $\begin{array}{l}405.7 \pm 109.7 \mathrm{~A} \\
159.1 \pm 59.8 \mathrm{~A} \\
178.5 \pm 60.6 \mathrm{~A} \\
195.0 \pm 68.3 \mathrm{~A}\end{array}$ & $\begin{array}{l}211.4 \pm 68.4 \\
67.3 \pm 23.3 \\
75.8 \pm 27.3 \\
94.1 \pm 35.7\end{array}$ & $\begin{array}{l}211.0 \pm 29.8 \\
60.0 \pm 0.8 \\
75.1 \pm 22.9 \\
91.1 \pm 32.6\end{array}$ \\
\hline $\begin{array}{l}\text { Base saturation } \\
(\%)\end{array}$ & $\begin{array}{l}0-0.5 \\
0.5-1.0 \\
1.0-1.5 \\
1.5-2.0\end{array}$ & $\begin{array}{l}44.3 \pm 7.4 \mathrm{~A}^{\dagger} \mathrm{ab}^{\dagger} \\
9.6 \pm 1.2 \mathrm{~A} \mathrm{a} \\
10.1 \pm 1.9 \mathrm{~A} \\
9.1 \pm 1.9 \mathrm{~A}^{\dagger}\end{array}$ & $\begin{array}{l}40.1 \pm 8.8 b^{\dagger} \\
4.8 \pm 0.8 b \\
4.6 \pm 0.2 \\
4.8 \pm 0.5\end{array}$ & $\begin{array}{l}33.0 \pm 4.1 \mathrm{~b}^{\dagger} \\
5.3 \pm 0.8 \mathrm{~b} \\
5.5 \pm 0.9 \\
6.5 \pm 2.7\end{array}$ & $\begin{array}{l}62.0 \pm 6.4 \mathrm{a}^{\dagger} \\
5.5 \pm 1.1 \mathrm{~b} \\
7.0 \pm 2.2 \\
6.3 \pm 1.2\end{array}$ \\
\hline
\end{tabular}

${ }^{1}$ Within row means followed by different lower case letters indicate significant difference between land-use types within a landscape (LME model with Fisher's LSD test at $\mathrm{P} \leq 0.05$ and marginally significant at ${ }^{+} \mathrm{P} \leq$ 0.09).

${ }^{2}$ Within column means followed by different upper case letters indicate significant difference between landscapes within a reference land use (LME model with Fisher's LSD test at P $\leq 0.05$ and marginally significant at ${ }^{\mathrm{P}} \leq 0.09$ ).

${ }^{3}$ Effective cation exchange capacity. 
Table 3.2. Soil nutrient stocks (means $\pm S E, n=4$ ) for each land-use type at four depth intervals within each landscape in Jambi, Sumatra, Indonesia.

\begin{tabular}{|c|c|c|c|c|c|c|c|c|c|}
\hline & & loam Acrisol l & idscape & & & clay Acrisol la & dscape & & \\
\hline $\begin{array}{l}\text { Soil nutrient } \\
\text { stocks }\end{array}$ & $\begin{array}{c}\text { Depth } \\
\text { (m) }\end{array}$ & $\begin{array}{c}\begin{array}{c}\text { Lowland } \\
\text { forest }\end{array} \\
\end{array}$ & $\begin{array}{l}\text { Jungle } \\
\text { rubber }\end{array}$ & $\begin{array}{c}\text { Rubber } \\
\text { plantation }\end{array}$ & $\begin{array}{c}\text { Oil palm } \\
\text { plantation }\end{array}$ & $\begin{array}{c}\begin{array}{c}\text { Lowland } \\
\text { forest }\end{array} \\
\end{array}$ & $\begin{array}{l}\text { Jungle } \\
\text { rubber }\end{array}$ & $\begin{array}{c}\text { Rubber } \\
\text { plantation }\end{array}$ & $\begin{array}{c}\text { Oil palm } \\
\text { plantation }\end{array}$ \\
\hline $\begin{array}{l}\text { Aluminum } \\
\left(\mathrm{g} \mathrm{Al} \mathrm{m}^{-2}\right)\end{array}$ & $\begin{array}{l}0-0.5 \\
0.5-1.0 \\
1.0-1.5 \\
1.5-2.0\end{array}$ & $\begin{array}{l}220.4 \pm 24.2 \\
345.6 \pm 42.6 \\
415.2 \pm 79.9 \\
484.4 \pm 148.6\end{array}$ & $\begin{array}{l}198.5 \pm 60.1 \mathrm{~B}^{\dagger} \\
209.6 \pm 80.4 \mathrm{~B}^{\dagger} \\
241.1 \pm 106.5 \mathrm{~B} \\
239.1 \pm 126.7 \mathrm{~B}\end{array}$ & $\begin{array}{l}256.6 \pm 37.6 \\
336.2 \pm 46.2 \\
314.4 \pm 45.1 \\
352.5 \pm 75.0\end{array}$ & $\begin{array}{l}187.5 \pm 50.3 \\
264.4 \pm 92.7 \\
271.7 \pm 105.4 \\
274.0 \pm 103.6\end{array}$ & $\begin{array}{l}320.5 \pm 181.9 \\
361.0 \pm 225.4 \\
487.5 \pm 326.3 \\
607.0 \pm 447.9\end{array}$ & $\begin{array}{l}556.9 \pm 160.2 \mathrm{~A}^{\dagger} \\
773.1 \pm 293.0 \mathrm{~A}^{\dagger} \\
970.4 \pm 332.4 \mathrm{~A} \\
1147.3 \pm 339.5 \mathrm{~A}\end{array}$ & $\begin{array}{l}295.7 \pm 102.7 \\
322.6 \pm 116.4 \\
408.4 \pm 152.6 \\
557.3 \pm 219.3\end{array}$ & $\begin{array}{l}246.6 \pm 40.5 \\
252.9 \pm 101.8 \\
404.5 \pm 132.9 \\
531.2 \pm 197.0\end{array}$ \\
\hline $\begin{array}{l}\text { Calcium } \\
\left(\mathrm{g} \mathrm{Ca} \mathrm{m}^{-2}\right)\end{array}$ & $\begin{array}{l}0-0.5 \\
0.5-1.0 \\
1.0-1.5 \\
1.5-2.0\end{array}$ & $\begin{array}{l}43.6 \pm 16.9 \\
13.5 \pm 1.0 \mathrm{~B}^{2} \\
18.2 \pm 0.7 \mathrm{~B}^{\dagger} \\
23.9 \pm 2.5\end{array}$ & $\begin{array}{l}24.1 \pm 5.7 \mathrm{~B}^{\dagger} \\
13.5 \pm 3.5 \\
14.6 \pm 2.3 \mathrm{~B} \\
18.3 \pm 3.0 \mathrm{~B}^{\dagger}\end{array}$ & $\begin{array}{l}37.5 \pm 8.2 \\
25.9 \pm 10.5 \\
16.5 \pm 1.7 \\
18.9 \pm 7.1\end{array}$ & $\begin{array}{l}65.1 \pm 17.1 \\
16.3 \pm 5.2 \\
13.1 \pm 2.8 \\
15.2 \pm 2.3\end{array}$ & $\begin{array}{l}79.3 \pm 49.5 \\
29.4 \pm 7.1 \mathrm{~A} \\
38.2 \pm 10.2 \mathrm{~A}^{\dagger} \\
33.4 \pm 10.5\end{array}$ & $\begin{array}{l}80.6 \pm 22.8 \mathrm{~A}^{\dagger} \\
37.8 \pm 12.1 \\
44.6 \pm 10.3 \mathrm{~A} \\
57.2 \pm 26.2 \mathrm{~A}^{\dagger}\end{array}$ & $\begin{array}{l}35.1 \pm 7.1 \\
20.9 \pm 2.6 \\
26.9 \pm 4.0 \\
30.1 \pm 1.1\end{array}$ & $\begin{array}{l}109.3 \pm 25.1 \\
20.6 \pm 1.0 \\
32.8 \pm 6.6 \\
37.0 \pm 3.7\end{array}$ \\
\hline $\begin{array}{l}\text { Iron } \\
\left(\mathrm{g} \mathrm{Fe} \mathrm{m}^{-2}\right)\end{array}$ & $\begin{array}{l}0-0.5 \\
0.5-1.0 \\
1.0-1.5 \\
1.5-2.0\end{array}$ & $\begin{array}{l}2.3 \pm 0.7 \mathrm{~B} \\
3.1 \pm 1.0 \\
3.1 \pm 0.7 \mathrm{a}^{1} \\
2.9 \pm 1.0\end{array}$ & $\begin{array}{l}1.1 \pm 0.4 \mathrm{~B} \\
1.0 \pm 0.6 \mathrm{~B} \\
0.9 \pm 0.2 \mathrm{~B} \mathrm{ab} \\
0.8 \pm 0.2 \mathrm{~B}^{\dagger}\end{array}$ & $\begin{array}{l}1.1 \pm 0.2 \\
1.2 \pm 0.8 \\
1.5 \pm 0.4 \mathrm{a} \\
5.0 \pm 4.4\end{array}$ & $\begin{array}{l}2.0 \pm 0.4 \\
0.6 \pm 0.3 \\
0.4 \pm 0.3 b \\
0.2 \pm 0.1\end{array}$ & $\begin{array}{l}5.3 \pm 1.4 \mathrm{~A} \\
2.5 \pm 0.7 \\
4.2 \pm 1.6 \\
2.2 \pm 0.6\end{array}$ & $\begin{array}{l}8.4 \pm 0.8 \mathrm{~A} \\
4.3 \pm 1.1 \mathrm{~A} \\
3.0 \pm 0.8 \mathrm{~A} \\
2.3 \pm 0.8 \mathrm{~A}^{\dagger}\end{array}$ & $\begin{array}{l}9.6 \pm 0.7 \\
5.4 \pm 0.5 \\
2.6 \pm 0.4 \\
6.0 \pm 2.8\end{array}$ & $\begin{array}{l}6.9 \pm 1.7 \\
8.6 \pm 4.6 \\
1.3 \pm 0.6 \\
4.2 \pm 2.7\end{array}$ \\
\hline $\begin{array}{l}\text { Magnesium } \\
\left(\mathrm{g} \mathrm{Mg} \mathrm{m}^{-2} \text { ) }\right.\end{array}$ & $\begin{array}{l}0-0.5 \\
0.5-1.0 \\
1.0-1.5 \\
1.5-2.0\end{array}$ & $\begin{array}{l}3.9 \pm 0.4 \\
4.5 \pm 1.4 \\
4.9 \pm 1.0 \\
6.8 \pm 2.0\end{array}$ & $\begin{array}{l}4.3 \pm 0.6 \mathrm{~B} \\
3.4 \pm 0.9 \\
3.2 \pm 0.5 \mathrm{~B}^{\dagger} \\
3.3 \pm 0.5\end{array}$ & $\begin{array}{l}9.2 \pm 3.2 \\
8.0 \pm 3.9 \\
4.7 \pm 0.8 \\
8.7 \pm 4.5\end{array}$ & $\begin{array}{l}4.3 \pm 2.2 \\
3.3 \pm 1.2 \\
4.1 \pm 1.8 \\
4.4 \pm 2.0\end{array}$ & $\begin{array}{l}18.2 \pm 10.7 \\
10.7 \pm 6.7 \\
12.7 \pm 7.9 \\
13.0 \pm 8.2\end{array}$ & $\begin{array}{l}39.2 \pm 16.3 \mathrm{~A} \\
17.8 \pm 9.4 \\
18.6 \pm 9.5 \mathrm{~A}^{\dagger} \\
23.1 \pm 11.6\end{array}$ & $\begin{array}{l}10.1 \pm 3.3 \\
5.6 \pm 1.8 \\
6.3 \pm 2.0 \\
7.2 \pm 2.6\end{array}$ & $\begin{array}{l}9.4 \pm 1.8 \\
3.8 \pm 0.9 \\
4.6 \pm 0.9 \\
8.2 \pm 4.1\end{array}$ \\
\hline $\begin{array}{l}\text { Manganese } \\
\left(\mathrm{g} \mathrm{Mn} \mathrm{m}^{-2} \text { ) }\right.\end{array}$ & $\begin{array}{l}0-0.5 \\
0.5-1.0 \\
1.0-1.5 \\
1.5-2.0\end{array}$ & $\begin{array}{l}0.6 \pm 0.1 \\
0.7 \pm 0.1 \\
0.8 \pm 0.1 \\
0.8 \pm 0.1\end{array}$ & $\begin{array}{l}0.8 \pm 0.3 \\
0.7 \pm 0.4 \\
0.6 \pm 0.2 \mathrm{~B}^{\dagger} \\
0.6 \pm 0.3\end{array}$ & $\begin{array}{l}1.3 \pm 0.4 \\
1.4 \pm 0.8 \\
0.8 \pm 0.2 \\
0.8 \pm 0.4\end{array}$ & $\begin{array}{l}1.0 \pm 0.4 \\
0.7 \pm 0.2 \\
0.6 \pm 0.2 \\
0.4 \pm 0.1\end{array}$ & $\begin{array}{l}11.6 \pm 8.1 \\
3.9 \pm 2.2 \\
5.5 \pm 3.4 \\
5.5 \pm 3.2\end{array}$ & $\begin{array}{l}7.1 \pm 2.2 \\
3.2 \pm 1.2 \\
4.6 \pm 2.5 \mathrm{~A}^{\dagger} \\
6.2 \pm 4.3\end{array}$ & $\begin{array}{l}2.2 \pm 0.5 \\
1.1 \pm 0.2 \\
1.1 \pm 0.2 \\
1.1 \pm 0.2\end{array}$ & $\begin{array}{l}6.4 \pm 2.8 \\
2.7 \pm 1.7 \\
3.5 \pm 2.4 \\
4.8 \pm 3.4\end{array}$ \\
\hline $\begin{array}{l}\text { Potassium } \\
\left(\mathrm{g} \mathrm{K} \mathrm{m}^{-2}\right)\end{array}$ & $\begin{array}{l}0-0.5 \\
0.5-1.0 \\
1.0-1.5 \\
1.5-2.0\end{array}$ & $\begin{array}{l}11.2 \pm 0.4 \\
10.4 \pm 8.1 \\
12.3 \pm 2.1 \\
19.9 \pm 5.3\end{array}$ & $\begin{array}{l}11.7 \pm 0.7 \mathrm{~B} \\
8.1 \pm 2.8 \\
9.5 \pm 4.5 \mathrm{~B}^{\dagger} \\
14.4 \pm 9.1 \mathrm{~B}^{\dagger}\end{array}$ & $\begin{array}{l}11.4 \pm 2.2 \\
11.2 \pm 3.5 \\
10.9 \pm 2.5 \\
18.7 \pm 8.1\end{array}$ & $\begin{array}{l}11.2 \pm 4.2 \\
9.7 \pm 2.7 \\
10.8 \pm 5.3 \\
13.9 \pm 6.7\end{array}$ & $\begin{array}{l}33.5 \pm 18.9 \\
31.7 \pm 22.4 \\
43.4 \pm 32.9 \\
49.4 \pm 38.0\end{array}$ & $\begin{array}{l}34.7 \pm 12.1 \mathrm{~A} \\
39.6 \pm 18.9 \\
56.8 \pm 23.5 \mathrm{~A}^{\dagger} \\
78.2 \pm 32.6 \mathrm{~A}^{\dagger}\end{array}$ & $\begin{array}{l}11.5 \pm 3.4 \\
8.6 \pm 3.2 \\
11.3 \pm 3.5 \\
17.3 \pm 6.5\end{array}$ & $\begin{array}{l}14.4 \pm 4.6 \\
13.1 \pm 3.4 \\
16.1 \pm 5.9 \\
24.9 \pm 10.9\end{array}$ \\
\hline $\begin{array}{l}\text { Sodium } \\
\left(\mathrm{g} \mathrm{Na} \mathrm{m}^{-2}\right)\end{array}$ & $\begin{array}{l}0-0.5 \\
0.5-1.0 \\
1.0-1.5 \\
1.5-2.0\end{array}$ & $\begin{array}{l}7.1 \pm 2.1 \\
7.2 \pm 5.9 \\
3.4 \pm 2.1 \mathrm{~A}^{\dagger} \mathrm{b} \\
3.9 \pm 2.6 \mathrm{~b}\end{array}$ & $\begin{array}{l}6.2 \pm 2.0 \\
5.8 \pm 2.6 \\
3.3 \pm 2.2 \mathrm{~b} \\
3.1 \pm 1.3 \mathrm{~b}\end{array}$ & $\begin{array}{l}7.3 \pm 1.9 \\
14.3 \pm 7.3 \\
2.5 \pm 1.7 \mathrm{~b} \\
6.7 \pm 2.8 \mathrm{~b}\end{array}$ & $\begin{array}{l}15.3 \pm 7.0 \\
19.6 \pm 3.7 \\
11.0 \pm 2.3 \mathrm{a} \\
27.8 \pm 4.2 \mathrm{a}\end{array}$ & $\begin{array}{l}4.3 \pm 0.7 \\
0.9 \pm 0.6 \\
0.8 \pm 0.7 \mathrm{~B}^{\dagger} \\
2.6 \pm 0.9 \mathrm{ab}^{\dagger}\end{array}$ & $\begin{array}{l}4.4 \pm 1.4 \\
2.3 \pm 1.0 \\
2.9 \pm 1.1 \\
4.6 \pm 1.4 \mathrm{a}^{\dagger}\end{array}$ & $\begin{array}{l}3.0 \pm 1.4 \\
1.0 \pm 0.2 \\
1.7 \pm 0.5 \\
0.7 \pm 0.4 \mathrm{~b}^{\dagger}\end{array}$ & $\begin{array}{l}4.0 \pm 1.0 \\
1.2 \pm 0.5 \\
1.6 \pm 0.4 \\
1.2 \pm 0.8 \mathrm{~b}^{\dagger}\end{array}$ \\
\hline $\begin{array}{l}\text { Extractable P } \\
\left(\mathrm{g} \mathrm{P} \mathrm{m}^{-2}\right)\end{array}$ & $\begin{array}{l}0-0.5 \\
0.5-1.0 \\
1.0-1.5 \\
1.5-2.0\end{array}$ & $\begin{array}{l}1.1 \pm 0.1 \mathrm{~B} \\
0.2 \pm 0.1 \mathrm{~B} \\
0.2 \pm 0.1 \\
0.1 \pm 0.1 \mathrm{~B}\end{array}$ & $\begin{array}{l}2.4 \pm 1.2 \\
0.3 \pm 0.0 \\
0.1 \pm 0.1 \\
0.1 \pm 0.0\end{array}$ & $\begin{array}{l}1.2 \pm 0.3 \\
0.3 \pm 0.1 \\
0.3 \pm 0.2 \\
0.0 \pm 0.0\end{array}$ & $\begin{array}{l}1.9 \pm 0.3 \\
0.2 \pm 0.1 \\
0.4 \pm 0.1 \\
0.2 \pm 0.1\end{array}$ & $\begin{array}{l}2.6 \pm 0.1 \mathrm{~A} \mathrm{ab} \\
1.1 \pm 0.3 \mathrm{~A} \mathrm{a} \\
0.7 \pm 0.3 \mathrm{a} \\
0.7 \pm 0.2 \mathrm{~A} \mathrm{a}\end{array}$ & $\begin{array}{l}1.5 \pm 0.1 \mathrm{bc} \\
0.3 \pm 0.1 \mathrm{~b} \\
0.2 \pm 0.1 \mathrm{a} \\
0.2 \pm 0.1 \mathrm{~b}\end{array}$ & $\begin{array}{l}0.8 \pm 0.1 \mathrm{c} \\
0.1 \pm 0.0 \mathrm{~b} \\
0.0 \pm 0.0 \mathrm{~b} \\
0.0 \pm 0.0 \mathrm{~b}\end{array}$ & $\begin{array}{l}6.1 \pm 3.2 \mathrm{a} \\
0.2 \pm 0.1 \mathrm{~b} \\
0.2 \pm 0.1 \mathrm{a} \\
0.1 \pm 0.0 \mathrm{~b}\end{array}$ \\
\hline
\end{tabular}

${ }^{1}$ Within row means followed by different lower case letters indicate significant difference between land-use types within a landscape (LME model with Fisher's LSD test at $\mathrm{P} \leq 0.05$ and marginally significant at ${ }^{\mathrm{P}} \mathrm{P} \leq 0.09$ ).

${ }^{2}$ Within row means followed by different upper case letters indicate significant difference between landscapes within a reference land use (LME model with Fisher's LSD test at $\mathrm{P} \leq 0.05$ and marginally significant at $+\mathrm{P} \leq 0.09$ ). 

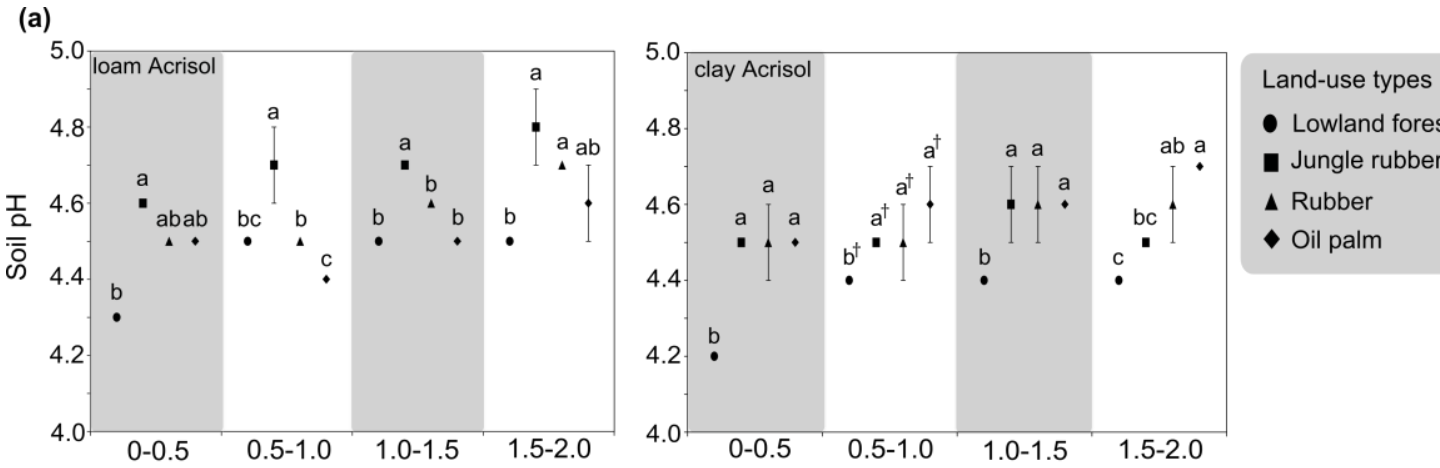

- Lowland forest

- Jungle rubber

$\Delta$ Rubber

- Oil palm
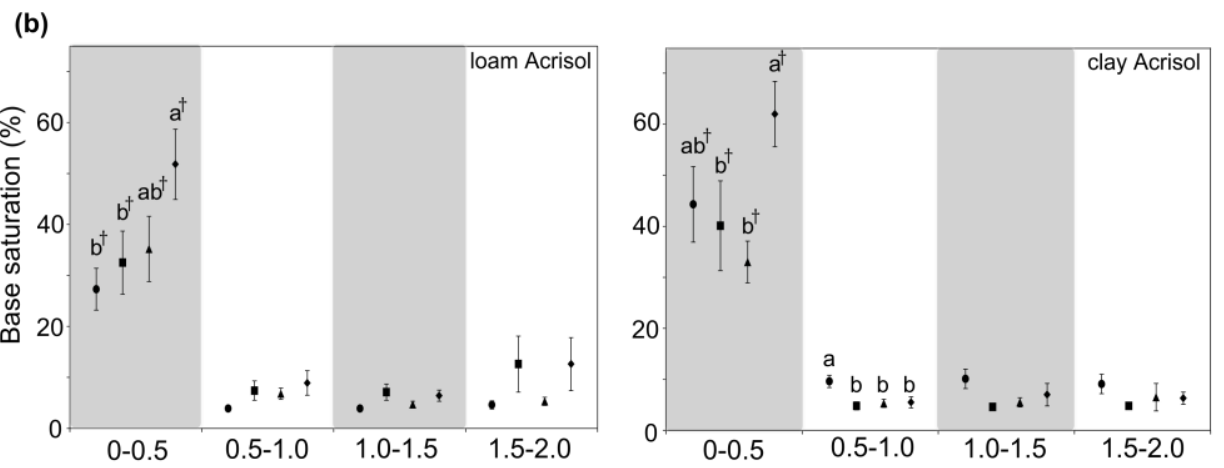

(c)
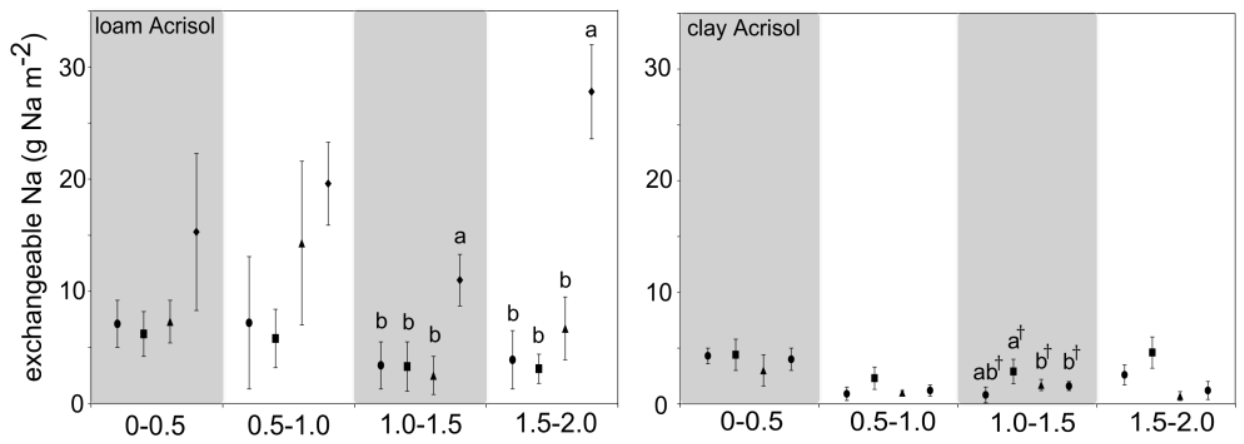

(d)
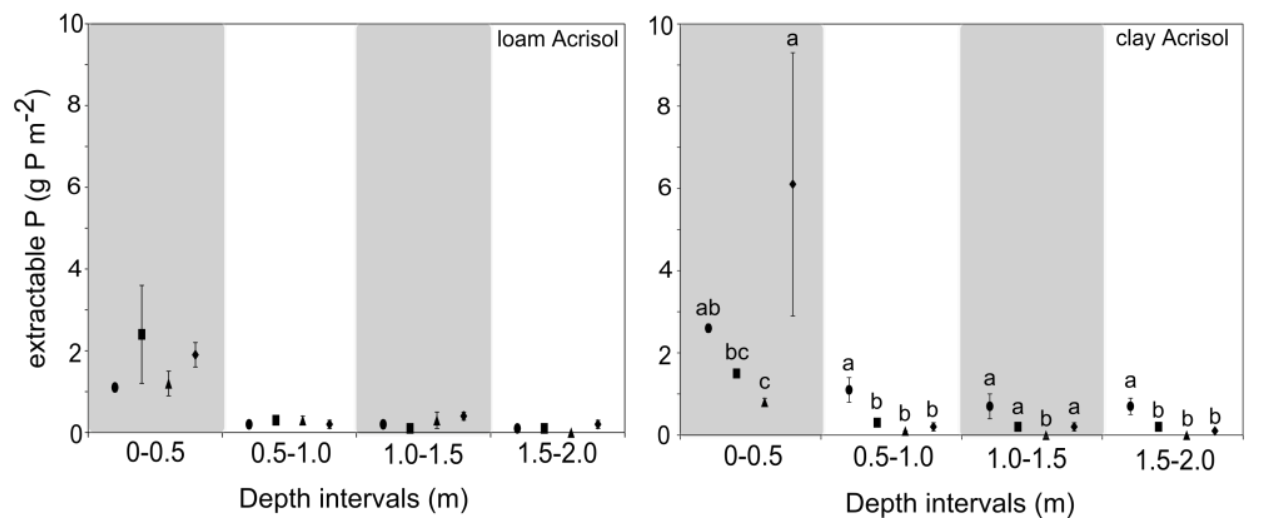

Fig. 3.1. Land-use change effects on (a) soil $\mathrm{pH}$, (b) base saturation, (c) exchangeable $\mathrm{Na}$ and (d) extractable $\mathrm{P}$ at each depth interval in the loam Acrisol (left column) and clay Acrisol (right column) soils. Lower case letters indicate significant differences between land-use types within a landscape (LME model with Fisher's LSD test at $\mathrm{P} \leq 0.05$ and marginally significant at $+\mathrm{P} \leq 0.09$ ). 


\section{Partitioning of variance and determining optimal sample size}

Variance components partitioning illustrated that soil $\mathrm{pH}$ and extractable $\mathrm{P}$ in all depth intervals were the only soil chemical characteristics that showed $>50-100 \%$ of variance accounted by the differences in land-use types (Figs. 3.2a-d), and thus also showed significant land-use type differences in all depth intervals (Figs. 3.1a, d). In general, a majority of the overall variance of the soil biochemical characteristics was accounted by the variation among replicate plots, especially in the lower three depth intervals (Figs. 3.2b-d). The few exceptions were ECEC and total N in the top depth (0-0.5 m) and SOC in all depth intervals for which the proportions of the overall variance accounted by the variation between landscapes were 25-70\% (Figs. 3.2a-d). Only a small proportion of the overall variance for the soil biochemical characteristics was accounted by variation among subplots within replicate plots (Figs. 3.2a-d).
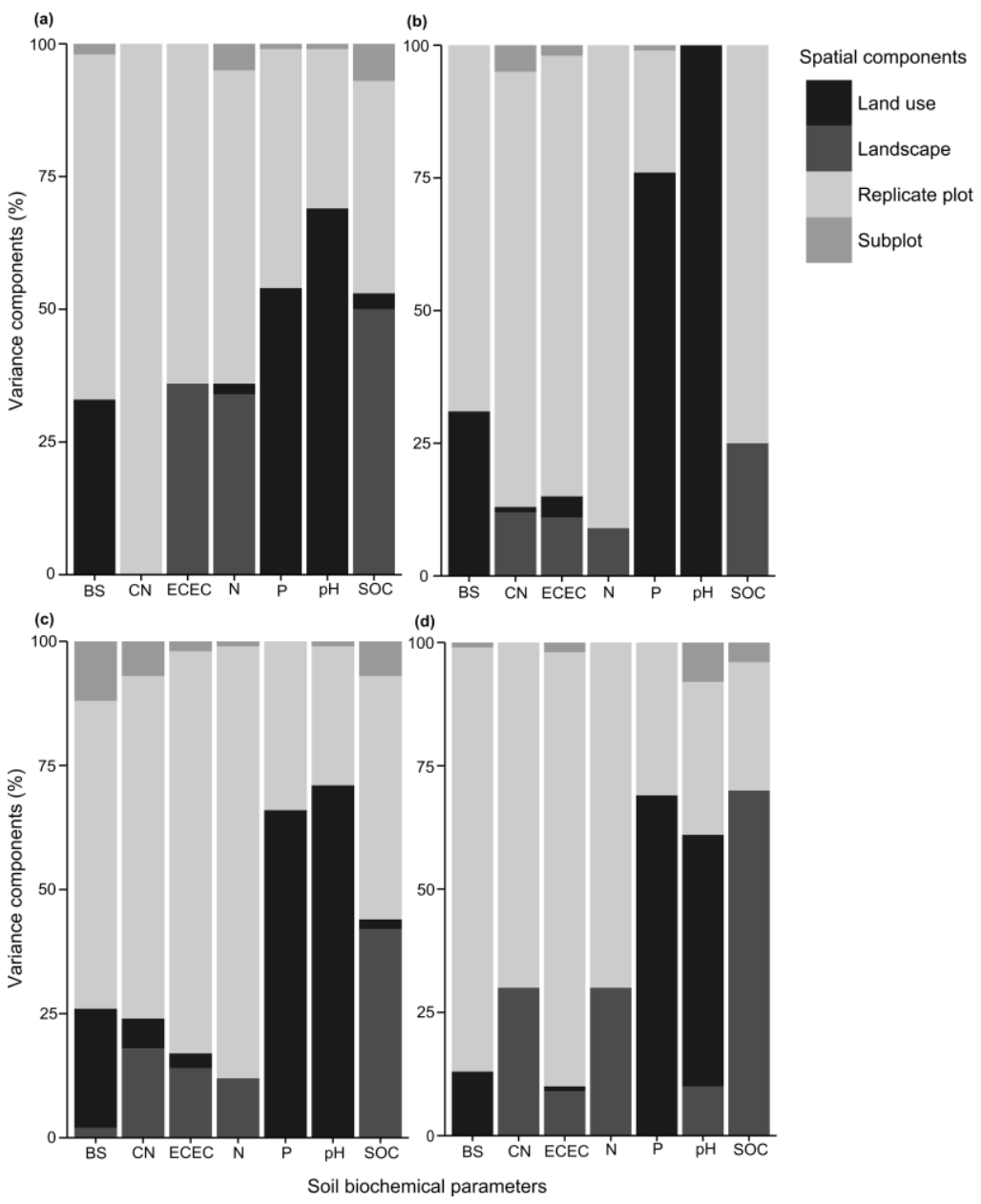

Fig. 3.2. Partitioning of the overall variance in soil biochemical characteristics in the depth intervals of (a) 0-0.5 m, (b) 0.5-1.0 m, (c) $1.0-1.5 \mathrm{~m}$ and (d) $1.5-2.0 \mathrm{~m}$ that is accounted by differences in land uses and by the spatial components (i.e., landscape, replicate plots within landscape and subplots within replicate plots) (LME model with variance components analysis (Crawley, 2007)). BS-base saturation; CN-organic carbon-to-total nitrogen ratio; ECEC-effective cation exchange capacity; N-total N, P-extractable phosphorus; SOC-soil organic C; pH-soil pH. 
Of the soil biochemical characteristics that we did not detect land-use type differences and that variation among replicate plots accounted for a large proportion of the total variance, SOC required the lowest optimum number of replicate plots per land-use type within each landscape (n=5; Fig. 3.3a). Total $\mathrm{N}$ and ECEC required 6 replicate plots per land-use type within each landscape (Figs. 3.3b, c) and the exchangeable bases (i.e., Ca and $\mathrm{K}$ ) required the highest number of replicate plots per land-use type within each landscape (n=7; Figs. 3.3d, e).
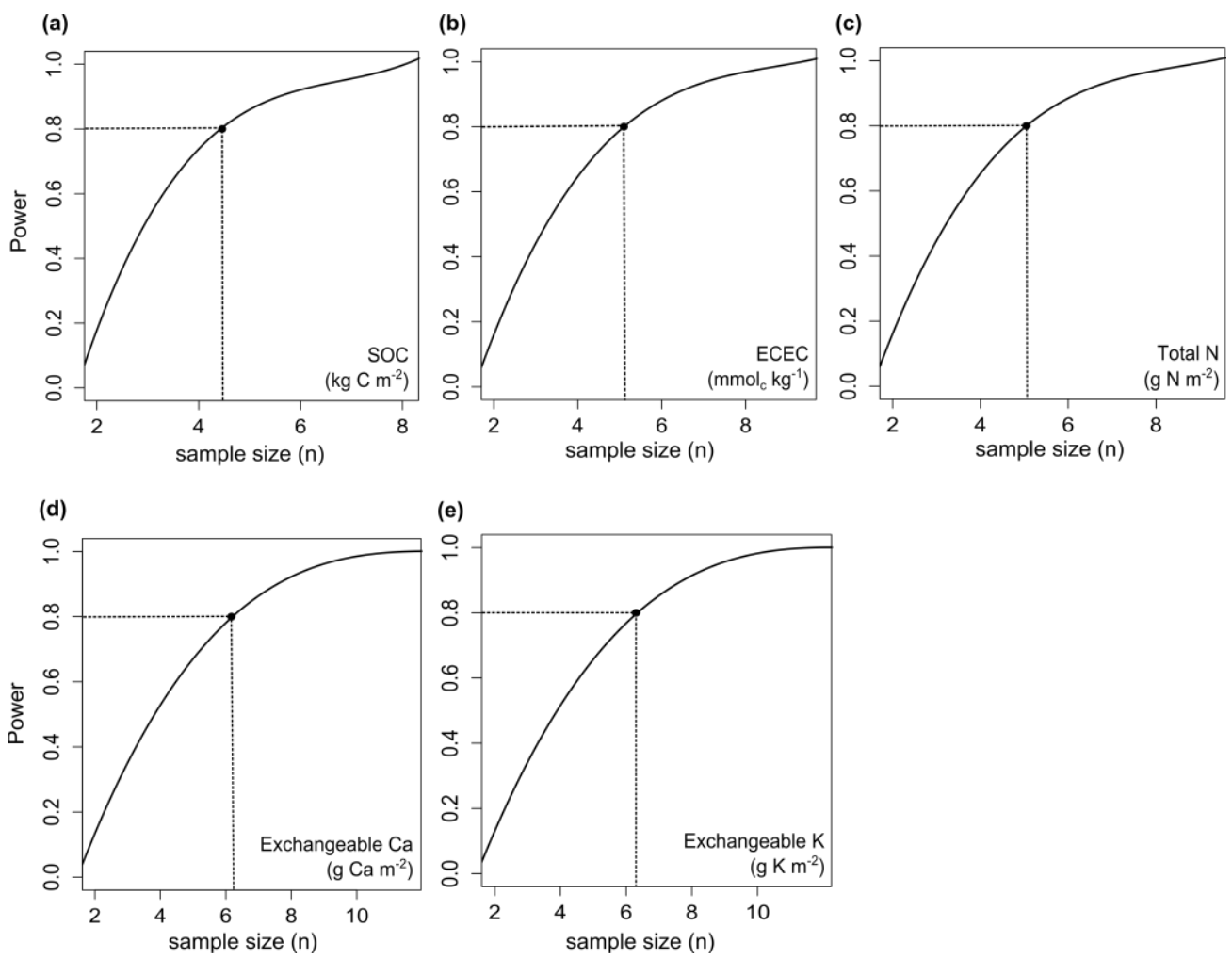

Fig. 3.3. Optimum sample size tested using one-way ANOVA power analysis with an $\alpha=0.05$ and a power of $80 \%$ per land-use type in each landscape needed to detect significant land-use change effects on (a) soil organic C (SOC), (b) effective cation exchange capacity (ECEC), (c) total N, (d) exchangeable $\mathrm{Ca}$ and (e) exchangeable $\mathrm{K}$.

\subsection{Discussion}

\section{Landscape-scale differences in soil nutrient stocks of the reference land uses}

In general, the Acrisol soils in our reference land uses (lowland forest and jungle rubber) were characterized by low soil fertility. Compared to relatively less weathered lowland forest soils (i.e., Cambisol and Nitisol) in Panama (Corre et al., 2010), our Acrisol soils exhibited lower levels of base nutrient ions and high levels of exchangeable $\mathrm{Al}$ down to $2 \mathrm{~m}$ depth. Clay content appeared to be the major controlling factor within this Acrisol soil group as indicated by the higher base 
saturation at all depths in the clay Acrisol forest plots and higher ECEC at all depths in the clay Acrisol jungle rubber plots (Table 3.1). A study conducted across a textural gradient in lowland Amazonian forests on highly weathered Ferrasol soils found that as clay content increases SOC, total $\mathrm{N}$ and ECEC also increase (Silver et al., 2000), corroborating our findings. The higher exchangeable $\mathrm{Ca}, \mathrm{Fe}, \mathrm{K}$ and to some extent Mg in all soil depths in the clay than loam Acrisol soils (Table 3.2) were also paralleled by the increasing clay content with depth (S2.2 Table; pg. 54). An ancillary study from the same study sites on nutrient leaching losses (measured at $1.5 \mathrm{~m}$ depth using suction lysimeters) from the forest plots showed that the loam Acrisol soil had higher fluxes of dissolved N, $\mathrm{Na}, \mathrm{Ca}, \mathrm{Mg}$ and total Al than the clay Acrisol soil (Kurniawan et al., unpublished data), supporting the larger nutrient stocks present in the clay than loam Acrisol soils. Although there were differences in soil $\mathrm{pH}$ of the reference land uses between landscapes, the range of soil pH we observed was within the Al-buffering range (through $\mathrm{Al}$ solubility at $\mathrm{pH}$ 3-5; Van Breemen et al., 1983), signifying the generally low acid buffering capacity typical in these Acrisol soils.

\section{Land-use change effects on soil nutrient stocks}

The legacy of biomass burning during conversion for both oil palm and rubber plantations coupled with the subsequent agricultural management practices associated with monoculture plantations strongly influenced soil $\mathrm{pH}$, base saturation and extractable $\mathrm{P}$ in the converted land uses (Figs. 3.1a, b, d; Tables 3.1 and 3.2). Soil pH, which was the only chemical property to exhibit landuse change effects at all depth intervals in both landscapes, was highest in the converted land uses in the clay Acrisol soil (Fig. 3.1a). This is most likely due to ashes from biomass burning of which effects on increasing soil pH can last for many years (Markewitz et al., 2001; van Straaten et al., 2015) as well as liming practices in oil palm plantations in this landscape during our study period and kieserite fertilizer application during years prior to our study. Furthermore, the increased base saturation in the top $0.5 \mathrm{~m}$ depth in the oil palm plantations in both soil landscapes was also influenced by legacy effects of biomass burning and liming (Fig. 3.1b). However, this increased base saturation was only surficial and the lower depths reflected the typically low base saturation of Acrisol soils (Fig. 3.1b). From an ancillary study conducted in the same plots during the same year, oil palm plantations showed increased leaching fluxes of $\mathrm{Na}, \mathrm{Ca}$ and $\mathrm{Mg}$ at $1.5 \mathrm{~m}$ depth compared to the forests (Kurniawan et al., unpublished data). Thus, although exchangeable base cations seemed high at the top depth, these large leaching losses require compensation through soil amendments, suggesting dependency of these smallholders on nutrient additions through fertilization. The high exchangeable $\mathrm{Na}$ in the oil palm plantations was due to borate fertilizer application during the years prior to our study; however, Na was also displaced to the lower depths via leaching (Kurniawan et 
al., unpublished data) as indicated by the higher exchangeable Na concentrations in the lowest two depth intervals, especially in the loam Acrisol soil (Fig. 1c). Hydrated $\mathrm{Na}$ ions are weakly adsorbed onto soil exchange sites, causing $\mathrm{Na}$ ions to be easily displaced with downward water movement (Schlesinger, 1997). Altogether, these results show that although fertilization in these oil palm plantations abated the decrease in soil nutrient stocks, this was only short-term and confined in the topsoil.

The differences in management practices between the two monoculture plantations illustrates that fertilization in the oil palm plantations not only contributes to the higher base saturation in the topsoil in this land use (described above), but also contributes to the higher extractable P in the topsoil, particularly in the clay Acrisol soil (Figs. 3.1b, d). The low extractable P in the rubber plantations signifies the eventual decrease in rock-derived nutrients after years of cultivation in unfertilized agricultural land uses (Ngoze et al., 2008). The lower extractable P and exchangeable bases present in the lower depths $(>0.5 \mathrm{~m})$ of the oil palm and rubber plantations compared to the forest may also be attributed to export of nutrients via harvest. Our estimates from oil palm plantations at these sites suggest that approximately $100 \mathrm{~kg} \mathrm{~N} \mathrm{ha}^{-1} \mathrm{yr}^{-1}, 10 \mathrm{~kg} \mathrm{P} \mathrm{ha}^{-1} \mathrm{yr}^{-1}$ and $80 \mathrm{~kg} \mathrm{~K} \mathrm{ha-1} \mathrm{yr}^{-1}$ can potentially be lost from the removal of oil palm plantation fruit bunches. Harvesting also contributes to biomass $\mathrm{C}$ losses (about $50 \%$ of the net primary production is removed through harvest in oil palm plantations and up to $20 \%$ in rubber plantations; Kotowska et al., 2015). Our results support previous findings in agricultural land uses in Indonesia that in unfertilized or non-agroforestry systems nutrient availability eventually declines overtime as export from harvest and leaching exceeds the internal supply of nutrients in the soil (Corre et al., 2006; Dechert et al., 2005, 2004; van Straaten et al., 2015). In summary, effects of land-use change were strongest only on those biochemical characteristics and nutrient stocks influenced by ashes from biomass burning and agricultural management practices, while the majority of soil parameters exhibited no statistically detectable effects of land-use change.

\section{Implications of the partitioned variance of soil biochemical characteristics}

It is generally expected that land-use conversion influences soil properties (e.g., (Corre et al., 2006; de Blécourt et al., 2013; Dechert et al., 2005, 2004; van Straaten et al., 2015), yet in this study, we were unable to detect significant effects of land-use type on many of our soil biochemical characteristics or soil nutrient stocks (Tables 3.1 and 3.2), with the exception of soil pH and extractable P that were both affected by land-use type at all depths (Figs. 3.1a, d; Tables 3.1 and 3.2). Variance components analysis also illustrated this result, as soil $\mathrm{pH}$ and extractable $\mathrm{P}$ had the highest proportions of overall variance accounted by land-use type (Figs. 3.2a-d). 
The fact that the majority of the overall variance of base saturation, C:N ratio, ECEC, total $\mathrm{N}$ and SOC in all depths was accounted by the variation amongst replicate plots (Figs. 3.2a-d) indicates that the number of replicate plots per land-use type within a landscape was insufficient to detect any significant effects of land-use change. This is corroborated by results from our power analysis (Figs. 3.3a-e). By increasing the number of replicate plots per land-use type per landscape by one to three, we could have potentially illustrated similar SOC losses as those found by van Straaten et al. (2015) in the same land uses in the same study region, as well as possibly demonstrated similar decreases in total $\mathrm{N}$ and exchangeable base cations (i.e., $\mathrm{K}$ ) as those found across fertilized and unfertilized agroecosystems in Sulawesi (Corre et al., 2006; Dechert et al., 2004). In contrast to the high variability between replicate plots, spatial variability within plots (subplot level within $50 \mathrm{~m} \times 50 \mathrm{~m}$ ) at each depth was low (Figs. 3.2a-d), illustrating that the number of subsamples taken for each depth interval (5 subsamples for 0-0.5 $\mathrm{m}$ and 2 subsamples for 0.5$2.0 \mathrm{~m}$ ) was sufficient to account for variation within replicate plots. The variance components analysis of SOC stocks, for which variation between landscapes accounted for a high proportion of the overall variance (Figs. 3.2a-d), provides further evidence of the influence of soil texture on SOC stock changes with land-use change. The control of soil texture is well-known through its effects on plant productivity, water availability and decomposition, influencing the balance between carbon inputs and outputs on SOC stability (de Koning et al., 2003; Powers et al., 2011; van Noordwijk et al., 1997; van Straaten et al., 2015). Our results also suggest that in order to detect the influence of landuse change on SOC stocks, field-based experimental designs must account for the influence of soil texture within a broad soil group in the same climatic conditions. Clustering sites based purely on land-use type without taking into account soil texture and type can lead to an underestimation in SOC losses with land-use conversion (e.g., Khasanah et al., 2015). Thus, in order to more accurately determine landscape-scale estimates of SOC changes due to land-use change, the landscape should be delineated into different soil textures and statistical analysis of land-use change must be done for each textural class within the same soil and climatic group.

In our study, where the experimental design was already based on differences in soil texture within the same soil group and climate, the large variation between replicate plots for each land-use may be contributed by the differing land-use ages between replicate plots, since age of land-use conversion influences the extent of changes in soil properties (e.g., SOC and soil-N cycling; Corre et al., 2006; de Blécourt et al., 2013; de Koning et al., 2003; van Straaten et al., 2015; Veldkamp, 1994). These studies have accounted the influence of land-use age, within a soil group, in their experimental design using the space-for-time substitution approach. This involves careful selection 
of replicate plots within the same soil and/or soil texture in the same climatic conditions to represent the ages of converted land uses. Compared to probability sampling, where a certain number of plots are selected at random across a study region, fewer replicate plots are typically needed in order to detect significant effects of land-use change when stratification in the region or landscape is based on known drivers of the soil properties of interest. Our study, as well as others (e.g., Chaplot et al., 2010; de Blécourt, 2013; Powers and Schlesinger, 2002), illustrates the high spatial variability in soil biochemical characteristics at a landscape scale in tropical systems. However, one method of stratification employed in one study may not be appropriate in another area with different sets of controlling drivers on the soil properties of interest. Therefore, conducting pilot studies in the anticipated study region and implementing analytical techniques such as variance components analysis and power analysis can be useful tools when designing largescale experiments in the tropics.

\subsection{Conclusions}

Clay content affected soil fertility at all depths within these highly weathered Acrisol soils, supporting our first hypothesis. The impacts of land-use change on soil biochemical characteristics and soil nutrient stocks at all depths were limited, and thus only partly support our second hypothesis. Only soil pH was altered by land-use change across all depths in each landscape largely due to the legacy of ashes from biomass burning during conversion and to liming practices employed in our oil palm plantations. Since the majority of the overall variation in soil biochemical characteristics was among replicate plots, except for SOC stocks which exhibited larger proportions of variation between landscapes than variation among plots, this did not support our third hypothesis. Our results indicate that in order to detect significant effects of land-use change on soil biochemical characteristics in our nested sampling experimental design, more replicate plots per land-use type within each landscape should be sampled. The high spatial variability of soil biochemical properties at the landscape scale illustrates that for extrapolation over large spatial scales, stratification must be based on the main driver (e.g., soil texture and/or land-use age within the same soil group and climatic condition) of the soil properties of interest. Therefore, future studies should focus on a range of soil parameters, test variability amongst plots or sites and determine the number of replications at the landscape level in order to determine overarching effects of land-use change on soil properties. 


\section{Acknowledgements}

We thank the village leaders, local plot owners, PT Humusindo, PT REKI, PT Perkebunan Nusantara VI, and Bukit Duabelas National Park for granting us access and use of their properties. We are especially grateful to our Indonesian field and laboratory assistants, Fahrurrozy Borland and Khairul Anwar (University of Jambi), as well as the rangers within the protected forest areas for their assistance during field sampling. We also thank Dodo Gunawan from the Meteorological, Climatological and Geophysical Agency of Indonesia for the climate data, and Andrea Bauer, Kerstin Langs and Martina Knaust (Georg-August University Göttingen, Germany) for their assistance with laboratory analyses. This study was financed by the Deutsche Forschungsgemeinschaft (DFG) in the framework of the collaborative German-Indonesian research project CRC990 subproject A05. Soil sampling was conducted using the collection permits 2703/IPH.1/KS.02/XI/2012 and S.13/KKH2/2013 recommended by the Indonesian Institute of Sciences (LIPI) and issued by the Ministry of Forestry (PHKA). 


\section{References}

Allen, K., Corre, M.D., Tjoa, A., Veldkamp, E., 2015. Soil nitrogen-cycling responses to conversion of lowland forests to oil palm and rubber plantations in Sumatra, Indonesia. PLoS One 10, e0133325. doi:10.5061/dryad.q20p3

Arnold, J., Corre, M.D., Veldkamp, E., 2009. Soil N cycling in old-growth forests across an Andosol toposequence in Ecuador. For. Ecol. Manage. 257, 2079-2087. doi:10.1016/j.foreco.2009.02.014

Baldos, A.P., Corre, M.D., Veldkamp, E., 2015. Response of N cycling to nutrient inputs in forest soils across a 1000-3000 m elevation gradient in the Ecuadorian Andes. Ecology 96, 749-761.

Barnes, A.D., 2015. Land-use impacts on biodiversity and ecosystem functioning of complex multitrophic communities. Georg-August University Göttingen.

Blake, G., Hartge, K., 1986. Bulk density, in: Klute, A. (Ed.), Methods of Soil Analysis, Part 1. Soil Science Society of America, Madison, WI, pp. 363-375.

Bray, R.H., Kurtz, L.T., 1945. Determination of total organic, and available forms of phosphorous in soils. Soil Sci. 59, 39-45.

Chaplot, V., Bouahom, B., Valentin, C., 2010. Soil organic carbon stocks in Laos: Spatial variations and controlling factors. Glob. Chang. Biol. 16, 1380-1393. doi:10.1111/j.1365-2486.2009.02013.x

Cohen, J., 1992. Statistical power analysis. Curr. Dir. Psychol. Sci. 1, 98-101.

Corre, M.D., Dechert, G., Veldkamp, E., 2006. Soil Nitrogen Cycling following Montane Forest Conversion in Central Sulawesi, Indonesia. Soil Sci. Soc. Am. J. 70, 359.

doi:10.2136/sssaj2005.0061

Corre, M.D., Veldkamp, E., Arnold, J., Wright, S.J., 2010. Impact of elevated N input on soil N cycling and losses in old-growth lowland and montane forests in Panama. Ecology 91, 1715-29.

Crawley, M.J., 2007. The R Book. John Wiley \& Sons, Ltd, Chichester, England.

Davidson, E. a, de Carvalho, C.J.R., Figueira, A.M., Ishida, F.Y., Ometto, J.P.H.B., Nardoto, G.B., Sabá, R.T., Hayashi, S.N., Leal, E.C., Vieira, I.C.G., Martinelli, L. a, 2007. Recuperation of nitrogen cycling in Amazonian forests following agricultural abandonment. Nature 447, 995-8. doi:10.1038/nature05900

De Blécourt, M., 2013. Impacts of land use and biophysical properties on soil carbon stocks in southern Yunnan, China. Georg August University Goettingen.

De Blécourt, M., Brumme, R., Xu, J., Corre, M.D., Veldkamp, E., 2013. Soil carbon stocks decrease following conversion of secondary forests to rubber (Hevea brasiliensis) plantations. PLoS One 8, e69357. doi:10.1371/journal.pone.0069357 
De Koning, G.H.J., Veldkamp, E., Lopez-Ulloa, M., 2003. Quantification of carbon sequestration in soils following pasture to forest conversion in northwestern Ecuador. Global Biogeochem. Cycles 17, $1-12$.

Dechert, G., Veldkamp, E., Anas, I., 2004. Is soil degradation unrelated to deforestation? Examining soil parameters of land use systems in upland Central Sulawesi, Indonesia. Plant Soil 265, 197209. doi:10.1007/s11104-005-0885-8

Dechert, G., Veldkamp, E., Brumme, R., 2005. Are partial nutrient balances suitable to evaluate nutrient sustainability of land use systems? Results from a case study in Central Sulawesi, Indonesia. Nutr. Cycl. Agroecosystems 72, 201-212. doi:10.1007/s10705-005-1546-2

Euler, M.A., 2015. Oil palm expansion among Indonesian smallholders-adoption, welfare implications and agronomic challenges. Georg-August University Goettingen.

Fargione, J., Hill, J., Tilman, D., Polasky, S., Hawthorne, P., 2008. Land clearing and the biofuel carbon debt. Science 319, 1235-8. doi:10.1126/science.1152747

Gee, G., Bauder, J., 1986. Particle-size analysis, in: Klute, A. (Ed.), Methods of Soil Analysis, Part 1. Soil Science Society of America, Madison, WI, pp. 383-411.

Hall, S.J., Matson, P.A., 2003. Nutrient Status of Tropical Rain Forests Influences Soil N Dynamics after N Additions. Ecology 73, 107-129.

Khasanah, N., van Noordwijk, M., Ningsih, H., Rahayu, S., 2015. Carbon neutral? No change in mineral carbon stock under oil palm plantations derived from forest or non-forest in Indonesia. Agric. Ecosyst. Environ. 211, 195-206.

Kotowska, M.M., Leuschner, C., Triadiati, T., Meriem, S., Hertel, D., 2015. Quantifying above- and belowground biomass carbon loss with forest conversion in tropical lowlands of Sumatra (Indonesia). Glob. Chang. Biol. n/a-n/a. doi:10.1111/gcb.12979

Markewitz, D., Davidson, E., Figueiredo, R., Victoria, R., Krusche, A., 2001. Control of cation concentrations in stream waters by surface soil processes in an Amazonian watershed. Nature 410, 802-805.

Ngoze, S., Riha, S., Lehmann, J., Verchot, L., Kinyangi, J., Mbugua, D., Pell, A., 2008. Nutrient constraints to tropical agroecosystem productivity in long-term degrading soils. Glob. Chang. Biol. 14, 2810-2822. doi:10.1111/j.1365-2486.2008.01698.x

Parkin, T.B., 1993. Spatial variability of microbial processes in soil-a review. J. Environ. Qual. 22, 409-417.

Pennock, D.J., Corre, M.D., 2001. Development and application of landform segmentation procedures. Soil Tillage Res. 58, 151-162.

Powers, J.S., Corre, M.D., Twine, T.E., Veldkamp, E., 2011. Geographic bias of field observations of soil carbon stocks with tropical land-use changes precludes spatial extrapolation. Proc. Natl. Acad. Sci. U. S. A. 108, 6318-22. doi:10.1073/pnas.1016774108 
Powers, J.S., Schlesinger, W.H., 2002. Relationships among soil carbon distributions and biophysical factors at nested spatial scales in rain forests of northeastern Costa Rica. Geoderma 109, 165190.

R Core Team, 2014. R: A language and environment for statistical computing.

Schlesinger, W.H., 1997. Biogeochemistry: an analysis of global change, 2nd ed. Academic Press, San Diego, CA.

Silver, W.L., Neff, J., McGroddy, M., Veldkamp, E., Keller, M., Cosme, R., 2000. Effects of Soil Texture on Belowground Carbon and Nutrient Storage in a Lowland Amazonian Forest Ecosystem. Ecosystems 3, 193-209. doi:10.1007/s100210000019

Sotta, E.D., Corre, M.D., Veldkamp, E., 2008. Differing N status and N retention processes of soils under old-growth lowland forest in Eastern Amazonia, Caxiuanã, Brazil. Soil Biol. Biochem. 40, 740-750. doi:10.1016/j.soilbio.2007.10.009

Van Breemen, N., Mulder, J., Driscoll, C.T., 1983. Acidification and alkalinization of soils. Plant Soil 75, 283-308.

Van Noordwijk, M., Cerri, C., Woomer, P.L., 1997. Soil carbon dynamics in the humid tropical forest zone. Geoderma 79, 187-225.

Van Straaten, O., Corre, M.D., Wolf, K., Tchienkoua, M., Cuellar, E., Matthews, R.B., Veldkamp, E., 2015. Conversion of lowland tropical forests to tree cash crop plantations loses up to one-half of stored soil organic carbon. Proc. Natl. Acad. Sci. 112, 9956-9960.

doi:10.1073/pnas.1504628112

Veldkamp, E., 1994. Organic carbon turnover in three tropical soils under pasture after deforestation. Soil Sci. Soc. Am. J. 58, 175-180.

Veldkamp, E., Becker, A., Schwendenmann, L., Clark, D.A., Schulte-Bisping, H., 2003. Substantial labile carbon stocks and microbial activity in deeply weathered soils below a tropical wet forest.

Glob. Chang. Biol. 1171-1184.

Wolf, K., Veldkamp, E., Homeier, J., Martinson, G.O., 2011. Nitrogen availability links forest productivity, soil nitrous oxide and nitric oxide fluxes of a tropical montane forest in southern Ecuador. Global Biogeochem. Cycles 25. doi:10.1029/2010GB003876 


\title{
Chapter 4
}

\section{Tropical land use imposes direct and cascading impacts on biodiversity from bacteria to birds}

\author{
Kara Allen, Andrew D. Barnes, Holger Kreft, Marife D. Corre, Malte Jochum, Edzo Veldkamp, \\ Yann Clough, Rolf Daniel, Kevin Darras, Lisa Denmead, Noor Farikhah Haneda, Dietrich \\ Hertel, Alexander Knohl, Martyna M. Kotowska, Syahrul Kurniawan, Ana Meijide, Katja \\ Rembold, Walesa Edho Prabowo, Dominik Schneider, Teja Tscharntke, and Ulrich Brose
}

Submitted to Science; Oct. 28, 2015

\begin{abstract}
Tropical land-use intensification to oil palm and rubber monocultures drives severe declines in biodiversity across a large range of interacting taxa. Yet, it remains unknown if direct or cascading effects of land use are responsible for causing these ecological shifts. Combining data from a multi-taxon research initiative, we test for direct versus cascading land-use effects across communities ranging from microbes to birds. At lower trophic levels, $90 \%$ of land-use impacts were direct, but $70 \%$ of impacts at the highest trophic levels were cascading. We demonstrate that the effects of tropical land use alternate from direct to cascading with increasing trophic level, collectively driving large-scale ecological shifts. Successfully preventing ecological collapses in agriculturally intensified ecosystems will therefore rely on incorporating species interactions into conservation management strategies.
\end{abstract}


Anthropogenic activities have altered most of the earth's ecosystems (1), largely through the expansion and intensification of agricultural landscapes for food production and biofuels (2-4). In tropical regions, which harbour exceptionally high levels of biodiversity (5), the conversion of rainforest to monoculture cash crops, such as oil palm and rubber, is currently the greatest threat to global biodiversity $(2,6-8)$. This threat will almost certainly worsen with rising global demands for food, fuel and fibre (9). Recent studies have shown that these monoculture systems are associated with reduced biodiversity across multiple trophic levels $(10,11)$, leading to impaired ecosystem functioning (11-13). Temperate and tropical research has long focused on how human land use directly affects one or two trophic groups (e.g., plants, butterflies or birds), without considering indirect, cascading effects via bottom-up forces $(14,4)$. In recent years, more attention has been turned toward quantifying land-use impacts on multitrophic systems (15). These studies effectively demonstrate that species interactions underlie the provisioning of ecosystem functioning and that neglecting these interactions may lead to biased inference on the extent of land-use consequences. Until now, research has been predominantly restricted to few trophic levels (15), without causal tests of cascading effects through multiple trophic levels across many higher-level taxa $(16,17)$. This research gap creates uncertainty about whether land-use impacts propagate upward through multiple trophic levels to the top of food chains directly (Fig. 4.1A) or indirectly via trophic cascades (Fig. 4.1B).
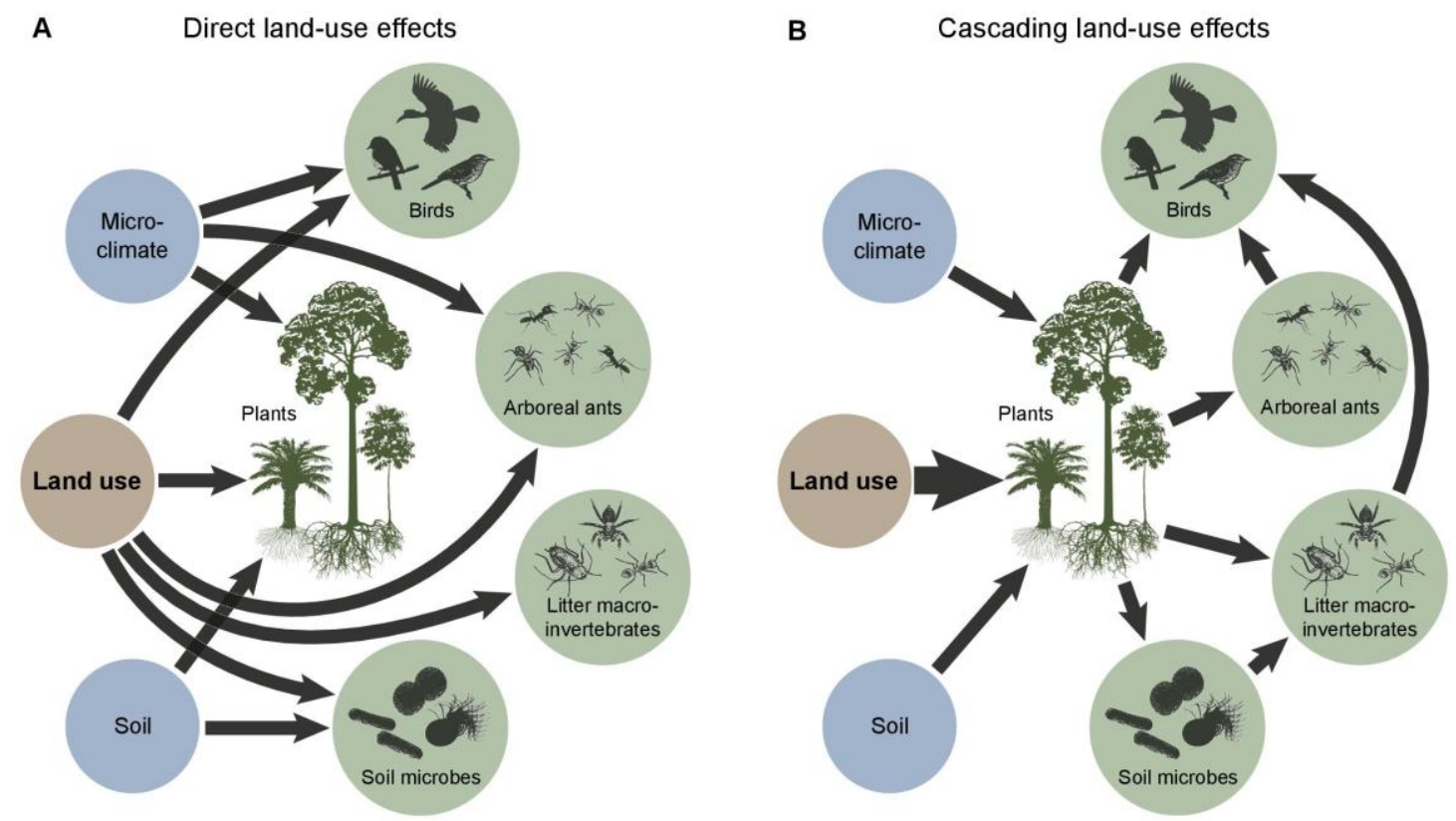

Fig. 4.1. Two alternative hypotheses for how land use may alter whole ecosystems. The direct landuse effects hypothesis (A) assumes land-use intensification directly impacts all taxonomic groups and trophic levels. The cascading land-use effects hypothesis (B) assumes that all impacts of landuse intensification at higher trophic levels propagate via cascading bottom-up processes. Only selected effects are represented for illustrative purposes (see fig. S4.3 for all hypothesised effects). Effects are grouped into those that emerge from land use (brown), abiotic (blue) and biotic variables (green). 
In order to grasp the scale of ecological change in altered tropical landscapes and to understand the mechanisms driving these changes, a multi-taxon whole-ecosystem approach is needed. In recent years, experimental research that manipulates plant diversity and composition has elucidated how primary producers influence the structure of food webs via bottom-up trophic cascades (18-22), demonstrating that organisms at lower trophic levels are key to understanding how whole ecosystems are structured and how they respond to environmental change. This notion has crucial implications for the way that land-use intensification will impact ecosystems and how such impacts will be most effectively assessed and mitigated. If theory suggests that the alteration of plant diversity and biomass should impose strong bottom-up trophic cascades $(19,20,23)$, these trophic cascades may be more important than the direct impacts of management practices in intensified land-use systems. On the one hand, direct land-use effects could dominate in cases such as pesticide application imposing direct toxic effects on invertebrates and microbes in intensively managed plantations (Fig. 4.1A). In contrast, cascading effects could prevail for consumers that may be strongly impacted by the depletion of their resources; an effect that could propagate from altered plant community composition and biomass (Fig. 4.1B). A clear understanding of these processes is critical for discerning the drivers of biodiversity decline and functional loss in anthropogenic landscapes, as well as being essential for making informed conservation management decisions across trophic levels.

Here, for the first time, we develop and test distinct hypotheses for the direct (Fig. 4.1A) versus cascading (Fig. 4.1B) effects of anthropogenic land use, employing a structural equation modelling framework to construct broad-scale food webs that include taxa ranging from microbes to birds (see Materials and Methods). Using data from an extensive multi-taxon research initiative, we sampled species richness (hereafter, 'diversity') and biomass of plants, bacteria, archaea, litter invertebrates, arboreal ants, and birds (table S4.1) in lowland forest, jungle rubber, rubber monocultures, and oil palm monocultures in Sumatra, Indonesia. Plant diversity and above- and belowground biomass were combined into a composite variable using principal components analysis in order to avoid issues of multicollinearity. Additionally, we created composite variables of 'soil organic matter', 'nutrient availability', and microclimatic variability (hereafter, 'microclimate') from soil properties and variability in atmospheric and soil microclimate (figs. S4.1 and S4.2). To test for direct (Fig. 4.1A) versus cascading land-use effects (Fig. 4.1B), we constructed generalised multilevel path models (24) (a form of structural equation modelling), allowing us to model direct and interactive effects of land use with abiotic variables versus biologically relevant, bottom-up trophic effects among biotic variables (see fig. S4.3 for all possible direct and cascading effects). 


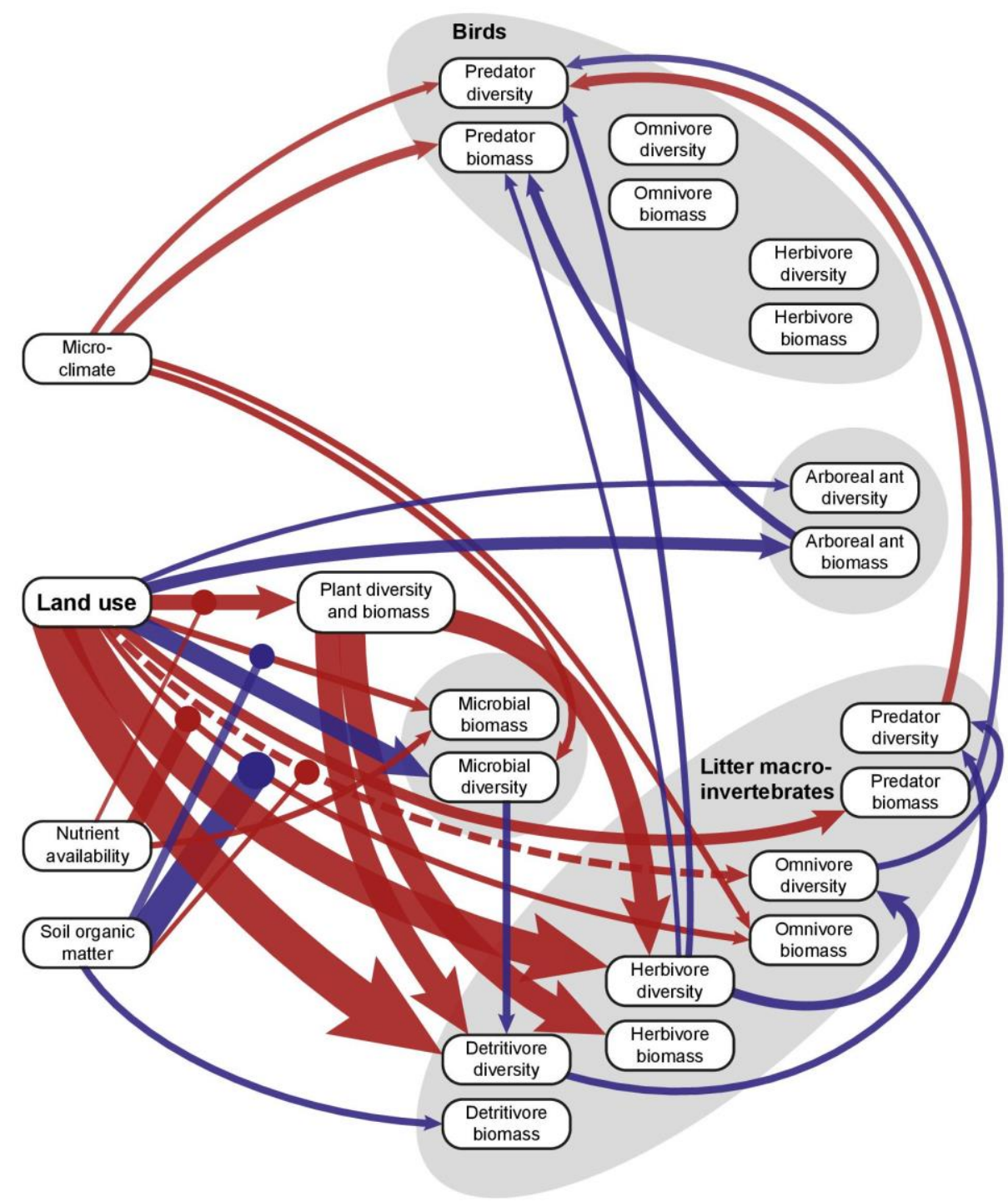

Fig. 4.2. Structural equation model testing direct versus cascading land-use effects in a tropical multitrophic system $\left(\chi^{2}=266.4, \mathrm{df}=276, \mathrm{P}=0.65\right)$. Solid red and blue arrows denote all significant negative and positive effects, respectively. Arrows ending in circular nodes that intersect the arrows originating from land use indicate a mediation of these effects (i.e., a significant interaction). Arrow widths are proportional to their absolute standardised effect sizes ( $z$-scores; see table S4.2, Materials and Methods).

Conversion of rainforest to oil palm and rubber agriculture imposed predominantly direct impacts (90\%) on plants, microbes and invertebrate primary and secondary consumers (i.e., detritivores, herbivores, and omnivores) (Fig. 4.2; table S4.2). Direct land-use effects on lower trophic levels were stronger than those at higher trophic levels, with relatively weaker direct effects on belowground omnivores and arboreal ants, and almost no direct effects on predator groups (Fig. 4.2). The majority of these direct effects (67\%) were negative and had considerably larger effect 
sizes than the cascading trophic effects (Fig. 4.3A), driving a clear overall decrease in diversity and biomass with conversion of forest to monoculture plantations (Fig. 4.2; fig. S4.4). These direct effects of land-use intensification most likely result from the intensive application of pesticides and fertilisers, disturbance of resource pools through the clearing of leaf litter, and habitat fragmentation (7). In other studies, heavy fertilisation has been clearly shown to reduce plant diversity and biomass through induced competitive exclusion (25), whereas fertilisation could possibly drive increases in microbial diversity (26) (Fig. 4.2; table S4.2). Interestingly, the number and strength of direct land-use effects steeply declined with increasing trophic level (Figs. 4.3B and C), indicating a shift away from the direct land-use effects hypothesis at higher levels in the food chain.
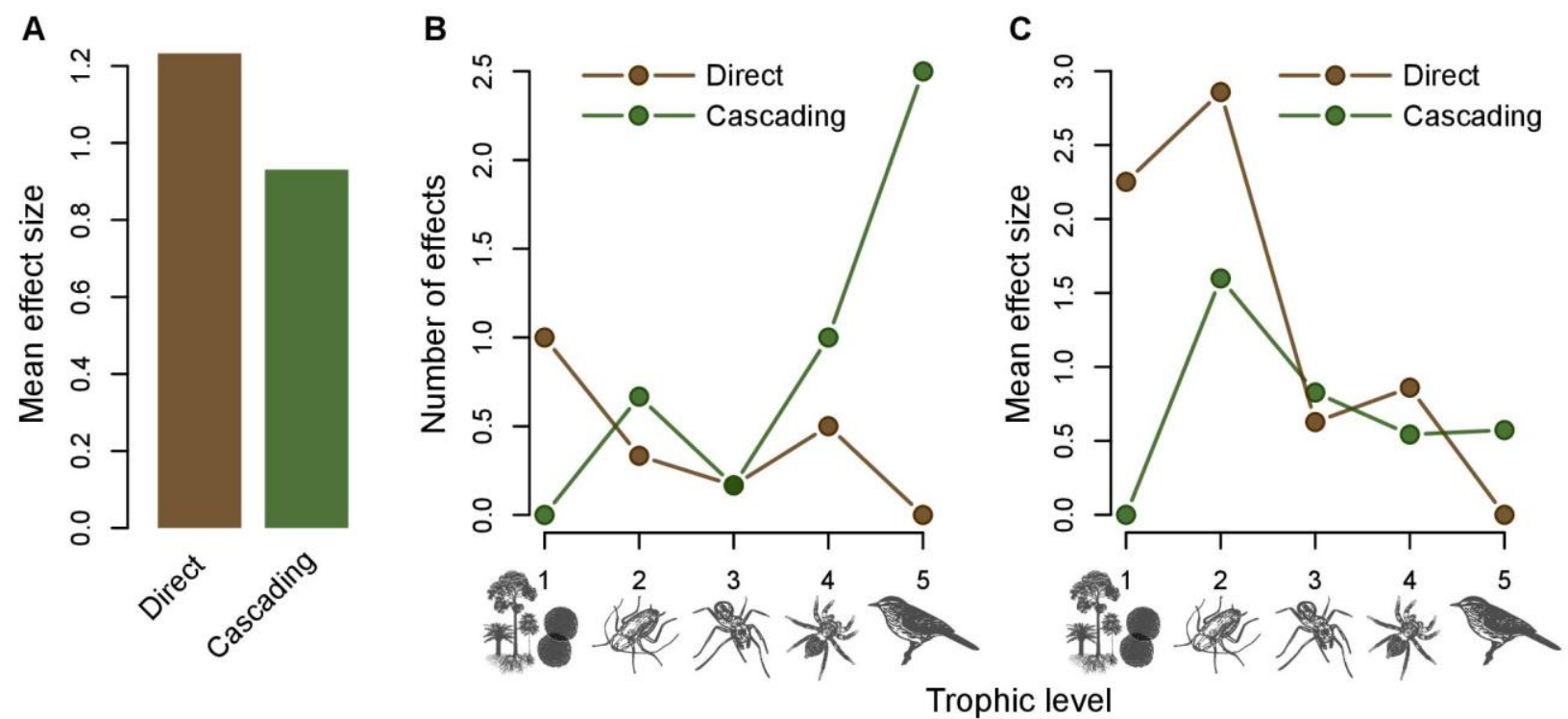

Fig. 4.3. Summary of land-use effects in the structural equation model. (A) is the within-group mean of the absolute standardised coefficients for all direct and cascading land-use effects. (B) shows the total number of direct and cascading land-use effects at each trophic level weighted by the number of response variables within each trophic level. (C) gives the mean effect size of all direct and cascading land-use effects that lead to each trophic level.

Many of the direct land-use effects were mediated by abiotic variables. For example, the negative impact of land-use change on plants was weakened by soil nutrient availability (Fig. 4.2; table S4.2). The frequency of interactive effects of background environmental variables with landuse intensification points to the importance of environmental heterogeneity and the landscape context in mediating the severity of land-use impacts. Despite this, the strongest direct land-use 
effects acted independently of environmental variables (e.g., on invertebrate detritivores and herbivores), indicating that the overall stronger impacts of land-use intensification (Fig. 4.3A) will often override potential interacting environmental variables. The novel combination of land-use intensification and abiotic variables to explore bottom-up control in taxonomically broad multitrophic systems aided in explaining a high proportion of variation within our models (ranging from $30 \%$ to $96 \%$, with a mean of $54 \%$; table S4.2).

Predatory groups were indirectly affected by land-use intensification (Fig. 4.2), with $90 \%$ of effects on these groups resulting from bottom-up trophic cascades. These cascading effects can be explained by strong direct effects of land-use intensification on biomass and diversity of lower trophic levels altering resource availability for higher trophic levels. In stark contrast to direct effects, cascading land-use effects increased dramatically in number from the lowest to highest trophic levels (Fig. 4.3B). Conversely, the strength of direct land-use effects strongly declined in comparison (Fig. 4.3C), indicating a shift in importance from direct to cascading land-use effects with increasing trophic level. Yet, the mean effect size of bottom-up trophic effects in our model decreased from detritivores to invertebrate omnivores, and to predatory invertebrates and birds (Fig. 4.3C). This could be due to greater disturbances of food resources at lower trophic levels (e.g., plants and soil microbes affected by frequent pesticide application) compared with intermediate trophic levels (invertebrate detritivores, herbivores, and omnivores) in higher-intensity agricultural systems. Further experimental exploration of this intriguing finding could reveal when trophic cascades are likely to be more intense and how to avoid potentially catastrophic trophic collapses (27).

Surprisingly, the effects of plant biomass and diversity on vegetation-associated trophic guilds (invertebrate herbivores and detritivores) were negative after controlling for all other variables in our model (Fig. 4.2; table S4.2). When the effects of plants on these trophic guilds were analysed without land use as a covariate, however, we found an overall positive effect of plant communities on the diversity of litter invertebrate detritivores (but no significant effects on invertebrate herbivore biomass and diversity) (fig. S4.5). Interestingly, plant diversity and biomass had a consistently positive effect on these taxa within oil palm, but generally negative or null effects in the less intensively managed systems. This finding suggests that at low levels of plant diversity and biomass typically used in experimental studies $(19,20)$, the relationship between plants and their consumers is most likely to be positive, but this could change markedly at much higher natural levels of diversity, such as in tropical rainforests. These findings could open interesting possibilities 
for future research into the role of plant diversity on higher trophic levels in biodiversity experiments, calling for the challenging task of incorporating real-world levels of species diversity.

We demonstrate that tropical land-use intensification drives large-scale ecological shifts across trophic levels via direct and cascading land-use effects. In essence, we find that as one moves upward in the food chain, land-use impacts shift from strong and direct effects to weaker and indirect effects that cascade upward via trophic interactions. At the bottom of the food chain, however, these direct impacts of land-use change are often mediated by environmental variation, collectively emphasising that ecosystems are highly complex and that human activities will yield equally complex consequences as ecosystems are altered. Amidst this complexity, our results elucidate the importance of focusing on conservation strategies that take into account shifting drivers of ecological change across the trophic spectrum.

\section{Acknowledgments}

We thank Raphael K. Didham and Jennifer S. Powers for providing helpful comments on earlier versions of this manuscript. We acknowledge the village leaders, local plot owners, PT Humusindo, PT REKI, PT Perkebunan Nusantara VI, and Bukit Duabelas National Park for granting us access and use of their properties and thank our permit granting bodies, the Indonesian Institute of Sciences (LIPI) and the Ministry of Forestry (PHKA). We also thank our Indonesian field and laboratory assistants, as well as the rangers within the protected forest areas for their assistance during field sampling and Dodo Gunawan from the Meteorological, Climatological and Geophysical Agency of Indonesia for the climate data. This study was financed by the Deutsche Forschungsgemeinschaft (DFG) in the framework of the collaborative German-Indonesian research project CRC990 and an FCS Swiss Government Scholarship. The data used in this paper are archived in the EFForTS-IS database: https://efforts-is.uni-goettingen.de 


\section{References}

1. P. M. Vitousek, H. A. Mooney, J. Lubchenco, J. M. Melillo, Human domination of Earth's ecosystems, Science 277, 494-499 (1997).

2. W. F. Laurance, J. Sayer, K. G. Cassman, Agricultural expansion and its impacts on tropical nature., Trends Ecol. Evol. 29, 107-16 (2014).

3. J. A. Foley et al., Global consequences of land use, Science 309, 570-574 (2005).

4. T. Newbold et al., Global effects of land use on local terrestrial biodiversity, Nature 520, 4550 (2015).

5. Y. Basset et al., Arthropod Diversity in a Tropical Forest, Science 338, 1481-1484 (2012).

6. D. S. Wilcove, X. Giam, D. P. Edwards, B. Fisher, L. P. Koh, Navjot's nightmare revisited: logging, agriculture, and biodiversity in Southeast Asia., Trends Ecol. Evol. 28, 531-40 (2013).

7. E. B. Fitzherbert et al., How will oil palm expansion affect biodiversity?, Trends Ecol. Evol. 23, 538-45 (2008).

8. H. Li, T. M. Aide, Y. Ma, W. Liu, M. Cao, Demand for rubber is causing the loss of high diversity rain forest in SW China, Biodivers. Conserv. 16, 1731-1745 (2007).

9. L. P. Koh, J. Ghazoul, Biofuels, biodiversity, and people: understanding the conflicts and finding opportunities, Biol. Conserv. 141, 2450-2460 (2008).

10. W. A. Foster et al., Establishing the evidence base for maintaining biodiversity and ecosystem function in the oil palm landscapes of South East Asia., Philos. Trans. R. Soc. B Biol. Sci. 366, 3277-91 (2011).

11. A. D. Barnes et al., Consequences of tropical land use for multitrophic biodiversity and ecosystem functioning, Nat. Commun. 5, 5351 (2014).

12. K. Allen, M. D. Corre, A. Tjoa, E. Veldkamp, Soil nitrogen-cycling responses to conversion of lowland forests to oil palm and rubber plantations in Sumatra, Indonesia, PLoS One 10, e0133325 (2015).

13. M. M. Kotowska, C. Leuschner, T. Triadiati, S. Meriem, D. Hertel, Quantifying above- and belowground biomass carbon loss with forest conversion in tropical lowlands of Sumatra (Indonesia)., Glob. Chang. Biol. 21, 3620-3634 (2015).

14. L. Gibson et al., Primary forests are irreplaceable for sustaining tropical biodiversity., Nature 478, 378-381 (2011).

15. J. M. Tylianakis, R. K. Didham, J. Bascompte, D. A. Wardle, Global change and species interactions in terrestrial ecosystems, Ecol. Lett. 11, 1351-1363 (2008). 
16. T. Tscharntke et al., Landscape moderation of biodiversity patterns and processes - eight hypotheses, Biol. Rev. 87, 661-685 (2012).

17. T. A. Gardner et al., Prospects for tropical forest biodiversity in a human-modified world, Ecol. Lett. 12, 561-582 (2009).

18. A. Ebeling et al., Plant diversity impacts decomposition and herbivory via changes in aboveground arthropods., PLoS One 9, e106529 (2014).

19. C. Scherber et al., Bottom-up effects of plant diversity on multitrophic interactions in a biodiversity experiment, Nature 468, 553-556 (2010).

20. E. T. Borer, E. W. Seabloom, D. Tilman, V. Novotny, Plant diversity controls arthropod biomass and temporal stability., Ecol. Lett. 15, 1457-64 (2012).

21. A. Narwani, A. Mazumder, Bottom-up effects of species diversity on the functioning and stability of food webs, J. Anim. Ecol. 81, 701-713 (2012).

22. R. F. Denno et al., Bottom-up forces mediate natural-enemy impact in a phytophagous insect community, Ecology 83, 1443-1458 (2002).

23. N. M. Haddad et al., Plant species loss decreases arthropod diversity and shifts trophic structure, Ecol. Lett. 12, 1029-1039 (2009).

24. B. Shipley, Confirmatory path analysis in a generalized multilevel context, Ecology 90, 363368 (2009).

25. Y. Hautier, P. A. Niklaus, A. Hector, Competition for light causes plant biodiversity loss after eutrophication, Science 324, 636-638 (2009).

26. B. Tripathi et al., Tropical soil bacterial communities in Malaysia: $\mathrm{pH}$ dominates in the equatorial tropics too, Microb. Ecol. 64, 474-484 (2012).

27. A. S. MacDougall, K. S. McCann, G. Gellner, R. Turkington, Diversity loss with persistent human disturbance increases vulnerability to ecosystem collapse, Nature 494, 86-89 (2013). 


\section{Supplementary material}

\section{Materials and Methods}

Study site and sampling design The study was carried out in Jambi Province, Sumatra, Indonesia. The study design was comprised of two landscapes with four land-use types common to the region: primary degraded forest (28), jungle rubber, and smallholder monoculture plantations of rubber (Hevea brasiliensis) and oil palm (Elaeis guineensis). In each landscape, four $50 \mathrm{~m} \times 50 \mathrm{~m}$ replicate sites per land-use type were selected with a minimum distance of $117 \mathrm{~m}$ between sites $(n=32)$ and five randomly selected $5 \mathrm{~m} \times 5 \mathrm{~m}$ subplots were established in each site. For a detailed description of the study region, study design, land-use types and management practices within the smallholder plantations see Allen et al. (12), Barnes et al. (11), Kotowska et al. (13) and Mumme et al. (29).

Soil characteristics Soil sampling design and soil biochemical analysis for pH, soil organic C (SOC; $\mathrm{kg} \mathrm{C} \mathrm{m}{ }^{-2}$ ), total $\mathrm{N}\left(\mathrm{g} \mathrm{N} \mathrm{m}^{-2}\right)$, effective cation exchange capacity (ECEC; $\mathrm{mmol}_{\mathrm{c}} \mathrm{kg}^{-1}$ ), base saturation $(\%)$, extractable $\mathrm{P}\left(\mathrm{g} \mathrm{P} \mathrm{m}^{-2}\right)$ and ${ }^{15} \mathrm{~N}$ natural abundance signatures $\left(\delta^{15} \mathrm{~N}^{0} \% 0\right)$ is described in detail in Allen et al.(12).

Soil texture (\% sand, \% silt and \% clay) was measured using the pipette method (30) from soil cores taken in the top $0.1 \mathrm{~m}$ soil depth from soil profiles dug at three of the four sites per land-use type $(n=24)$. The core method was used to measure soil bulk density for the top $0.5 \mathrm{~m}$ soil depth from two subplots (31). Soil bulk density $\left(\mathrm{g} \mathrm{cm}^{-3}\right)$ for each site was represented by the mean of the two individual subplots. Soil moisture (\%) was measured using moisture sensors (IMKO Trime-PICO, Ettlingen, Germany) recorded every hour with a data logger (see Microclimatic variability). Soil sampling was conducted using the collection permits 2703/IPH.1/KS.02/XI/2012 and S.13/KKH2/2013 issued by the Indonesian Institute of Sciences (LIPI) and the Ministry of Forestry (PHKA).

Microclimatic variability Weather stations were installed in the centre of each of the 32 sites. They were equipped with thermohygrometers (Galltec Mella, Bondorf, Germany) placed at a height of $2 \mathrm{~m}$ to record air temperature $\left({ }^{\circ} \mathrm{C}\right.$ ) and humidity (\%) inside the canopy, and soil sensors (IMKO Trime-PICO, Ettlingen, Germany) at $0.3 \mathrm{~m}$ depth, to monitor soil temperature $\left({ }^{\circ} \mathrm{C}\right)$ and moisture (\%). Both sensors were connected to a data logger (LogTrans16-GPRS, UIT, Dresden, Germany) and measured every hour. The $5^{\text {th }}$ and $95^{\text {th }}$ percentiles, from data available for the period June 2013 to October 2014, for air temperature, humidity and soil temperature were used to calculate ranges for each variable. Climate data were collected using the research permits 389/FRP/SM/II/2013 and 05/EXP/SIP/FRP/SM/II/2014 issued by LIPI and PHKA.

Above- and belowground plant biomass and diversity Within each site, the diameter and height of all trees, palms and lianas with a diameter at breast height (DBH) $\geq 10 \mathrm{~cm}$ (DBH at $1.3 \mathrm{~m}$ ) were measured. Wood density values (dry mass per fresh volume in $\mathrm{kg} \mathrm{m}^{-3}$ ) were measured for extracted cores of 204 trees. The interpolated wood density values were applied on the remaining trees based on a calibration equation with pin penetration depth measured using a Pilodyn 6J wood tester (PROCEQ SA, Zürich, Switzerland). Additionally, forest understory trees with a diameter of 2 $9.9 \mathrm{~cm}$ were inventoried as described above, within two subplots in each site. To convert the recorded tree structural data into aboveground plant biomass (AGB; $\mathrm{Mg} \mathrm{ha}^{-1}$ ), the allometric equations developed by Chave et al. (32) for all forest trees, Wauters et al. (33) for rubber trees, Asari et al. (34) for oil palms and Schnitzer et al. (35) for lianas were applied.

To calculate coarse root and root-stock biomass (BGB; $\mathrm{Mg} \mathrm{ha}^{-1}$ ), we used the allometric equations developed by Niiyama et al. (36) for forest trees, Wauters et al. (33) for rubber trees and 
Syahrinudin (37) for oil palms. We added our measurements of small-diameter $(\leq 2 \mathrm{~mm})$ root biomass to the calculated total biomass. Fine root biomass was measured using ten vertical soil cores ( $3.5 \mathrm{~cm}$ in diameter) down to $0.5 \mathrm{~m}$ soil depth, including the organic layer, in each site. All fine root segments longer than $1 \mathrm{~cm}$ were extracted by washing over a $200 \mu \mathrm{m}$ sieve and separated under a stereomicroscope into live (biomass) and dead fractions (necromass).

Woody coarse debris was analysed within all forest and jungle rubber sites where snags (DBH $\geq 10$ $\mathrm{cm}$ ) and logs (mid-point diameter $\geq 10 \mathrm{~cm}$, length $\geq 1 \mathrm{~m}$ ) were recorded. This was not measured in monoculture rubber and oil palm plantations because woody coarse debris is cleared regularly due to plantation management. Three decay stages based on Grove (38) were used to characterise the woody debris. Biomass of the debris was calculated using the equations by Kauffmann and Donato (39) and by applying the allometric equation by Chave et al. (32) for calculating AGB of nondegraded trees. Above- and belowground biomass sampling was conducted using the collection permit 2704/IPH.I/KS.02/X1/2012 issued by LIPI and PHKA.

In each site, all trees with $\mathrm{DBH} \geq 10 \mathrm{~cm}$ were identified and measured (spatial position within the site, height, DBH, crown structure). Additionally, all vascular plant individuals growing within the five subplots were identified and measured (height). Whenever possible, herbarium specimens were prepared from three individuals per species for identification and were later archived at several Indonesian herbaria (Herbarium Bogoriense, BIOTROP Herbarium, UNJA Herbarium, Harapan Rainforest Herbarium). All individuals measured on the sites were identified to morphospecies based on consistent morphological characteristics. Plant diversity was calculated as total sampled species richness within each site. Vascular plant sampling was conducted using the collection permit 2266/IT3/PL/2013 issued by LIPI and PHKA.

Microbial biomass and diversity Microbial biomass $\mathrm{C}\left(\mathrm{mg} \mathrm{C} \mathrm{kg}^{-1}\right)$ was measured from soil cores sampled in two subplots. The $\mathrm{CHCl}_{3}$ fumigation-extraction method was followed $(40,41)$. A subsample of soil from a core was extracted immediately with $0.5 \mathrm{~mol} \mathrm{~L}^{-1} \mathrm{~K}_{2} \mathrm{SO}_{4}$ (unfumigated) and another subsample was fumigated with $\mathrm{CHCl}_{3}$ for six days and then extracted (fumigated). Organic $\mathrm{C}$ in the extracts was analysed by UV-enhanced persulfate oxidation using a Total Organic Carbon Analyser (TOC-Vwp, Shimadzu Europa GmbH, Duisburg, Germany) with an infrared detector. Microbial biomass $C$ was calculated as the difference in extractable organic $C$ between the fumigated and unfumigated soils divided by $\mathrm{k}_{\mathrm{C}}=0.45$ for a six-day fumigation period (40). Microbial biomass sampling was conducted under the same collection permits as those for the soil sampling above.

Sampling of soils for microbial diversity (top 0.5 to $0.7 \mathrm{~m}$ ) was carried out in three subplots in each site. All samples were stored at $-80^{\circ} \mathrm{C}$ until further use. DNA was isolated by employing the PowerSoil DNA isolation kit as recommended by the manufacturer (Dianova, Hamburg, Germany). Subsequently, 16S rRNA gene amplicons of Bacteria and Archaea were generated from the isolated DNA as described by Schneider et al. (42). The resulting $16 \mathrm{~S}$ rRNA gene datasets were processed and analysed by employing QIIME 1.8 (43). Initially, sequences shorter than $300 \mathrm{bp}$, containing unresolved nucleotides, exhibiting an average quality score lower than 25 , harbouring mismatches longer than $3 \mathrm{bp}$ in the forward primer, or possessing homopolymers longer than $8 \mathrm{bp}$ and primer sequences were removed. Sequencing noise and potential chimeric sequences were resolved by using Acacia (44) and UCHIME (45) with RDP (46) as reference datasets (trainset10_082014_rmdup.fasta). Operational taxonomic unit (OTU) determination was performed at a genetic divergence of 3\% by using pick_open_reference_otus.py of the QIIME 1.8 package using the Silva NR SSU 119 database version as a reference $(43,47)$. Taxonomic classification was performed with parallel_assign_taxonomy_blast.py against the same database. Unclassified OTUs and OTUs occurring as singletons (sequences observed fewer than 2 times), chloroplasts, and extrinsic domains were removed. OTU tables were subsampled and comparisons were performed at the same surveying effort (Bacteria 6.800 and Archaea 2.000 sequences per subplot). Diversity 
estimates were generated employing alpha_rarefaction.py. The 16S rRNA gene sequences were deposited in the National Center for Biotechnology Information (NCBI) Sequence Read Archive (SRA) under study accession number SRP056374. Microbial diversity sampling was conducted using the collection permit 2701/IPH.I/KS.02/XI/2012 issued by LIPI and PHKA.

Litter macroinvertebrate biomass and diversity In each of the sites, three subplots were sampled by sieving $1 \mathrm{~m}^{2}$ leaf litter through a coarse $2 \mathrm{~cm}$ mesh-width sieve. 7472 macroinvertebrates were hand-collected from the sieving samples and stored in 65\% ethanol. Specimens were identified to morphospecies and, based on morphology and literature, assigned to one of four feeding guilds: omnivores, detritivores, predators and herbivores. To assess sampling completeness, observed species richness was compared to both extrapolated and rarefied species richness, which revealed that the mean estimated sampling coverage was $56 \%$ and observed species richness was highly correlated with extrapolated species richness (11). As such, observed species richness provided representative sampling of real species richness in these tropical agricultural systems. For each of the 7472 animals collected, individual body lengths were measured and then converted to fresh body mass using allometric length-mass regressions from the literature (11). Community biomass (fresh mass in $\mathrm{mg} \mathrm{m}^{-2}$ ) was then calculated for each of the 32 sampled communities by summing together all individual body masses calculated from length-mass regressions as derived from the individually measured body lengths. All organisms were collected based on Permit No. 51/KKH-5/TRP/2014 issued by LIPI and PHKA.

Arboreal ant biomass and diversity Plastic observation plates with two baits of $2 \mathrm{~cm}^{3}$ of tuna in oil and two sponges saturated with $70 \%$ sucrose solution attached were used to sample arboreal ant species (48). One plate was tied at breast height on two trees within five subplots in each site. If there were not two trees in a subplot (often the case in oil palm plantations), the closest trees to the subplot were chosen. Sixty minutes after placing the plates on the trees, the abundance of each ant species present on the plate was recorded and a number of specimens were collected. Ant species abundance at a given site was defined as the mean of all recorded abundances in a site. Surveys were conducted in each site four times between November 2012 and February 2014, between 9:00 am and 11:00 am. No sampling was conducted during or immediately after rain due to a reduction in ant activity in wet conditions. All collected ants (Hymenoptera: Formicidae) were identified to genus using published keys (49). We identified specimens to species level where possible and assigned the remainder to morphospecies. Body length was measured on up to five individuals from each species at each site and, using a length-mass regression specific to ants (50), an average fresh body mass was calculated for each species. Ant community biomass (mg) for each site was calculated by summing the total biomass of each species (abundance $\times$ average species body mass) present. Arboreal ant sampling was conducted using the collection permit 11055/IT3/PL/2012 issued by LIPI and PHKA.

Bird biomass and diversity Birds were sampled using point counts located in the centre of the sites. All birds detected visually and aurally within the site were recorded for 20 minutes between 6:00 am and 10:00 am in June to July 2013. The timing of bird data collection alternated between early and late morning and all sites were visited three times. Individuals flying above the canopy were excluded and unfamiliar bird calls were recorded using a directional microphone (Sennheiser ME66). The recordings were compared with an available online bird call database (www.xenocanto.org) for confirmation. Bird species identification in the field follows Mackinnon \& Phillips (51), but thereafter, species names were translated to Birdlife International nomenclature. Body mass and feeding guilds for each bird species were retrieved from Wilman et al. (52) and assigned to each individual recorded. Bird species were divided into 3 main feeding guilds: herbivores (granivores, nectivores, and frugivores), predators (insectivores), and omnivores (insectivores 
and/or granivores, nectivores, and frugivores). Total biomass for each site was calculated by summing together species-specific body sizes for all individuals sampled.

\section{Statistical analyses}

Principal Components Analysis To reduce the number of parameters in our models and avoid issues of multicollinearity whilst maintaining as much variability in our predictors as possible, composite variables were calculated using principal components analysis (PCA; 'princomp' function in R (53)) from soil, microclimatic, and plant community parameters. Soil components were created using a combination of soil biochemical properties and soil physical properties(54). Following Swaine (54), soil physical properties were first composited to create a soil physical component. Including soil texture (\% sand, \% silt, \% clay), soil bulk density, and soil moisture within the soil physical component, the first principal component (PC1) accounted for $53.5 \%$ of the total variation (fig. S4.1). The physical component PCA scores from the PC1 were plotted against the soil physical variables with the highest loadings $(\geq 0.400)$ in order to ascertain trends within the component (fig. S4.2). \% Sand had negative loading, and \% clay and soil moisture had positive loadings (fig. S4.1), illustrating that the lower PC1 scores represented coarser textured drier soil conditions and the higher PC1 scores represented finer textured wetter soil conditions (fig. S4.2).

The soil physical component was then combined with soil biochemical variables (e.g., soil pH, SOC, total N, C:N ratio, extractable P, ECEC, base saturation and $\left.\delta^{15} \mathrm{~N}\right)(54)$ in a new PCA. Two composite variables were created representing the soil conditions from the first (PC1) and second (PC2) principal components. PC1 and PC2, combined, accounted for $57.2 \%$ of the total variation (fig. S4.1). Soil PC1 was termed Nutrient Availability and reflects the level of acid and base cations in the soil. The higher PC1 scores represented soil conditions with higher nutrient availability and the lower PC1 scores represented soil conditions with lower soil nutrient availability (fig. S4.2). Soil PC2 was termed Soil Organic Matter, as the higher PC2 scores represented soil conditions with higher SOC, lower soil $\mathrm{pH}$, and less decomposed organic matter (as evident by the lower $\delta^{15} \mathrm{~N}$ values) and the lower PC2 scores represented soil conditions with less SOC, higher soil pH, and more decomposed organic matter. PC2 is also dependent on the agricultural management practices that took place in the land-use systems in this study. Soil amendments such as liming and ash from burning during conversion increased soil pH (12). Additionally, weeding, herbicide use and harvest export reduced the organic matter input (13), which in turn resulted in highly decomposed organic matter (i.e., higher $\delta^{15} \mathrm{~N}$ signatures).

Using ranges calculated from the $5^{\text {th }}$ and $95^{\text {th }}$ percentiles for air temperature, humidity and soil temperature, a composited variable representing microclimatic variability was created with a PCA. The PC1 axis accounted for 70.1\% of the total variation (fig. S4.1). Relationships between the microclimatic variables and the PC1 scores illustrated that the PC1 scores were strongly positively correlated with microclimatic variability (fig. S4.2).

Because plant diversity, as well as above- and belowground plant biomass were highly correlated (90.36\%; fig. S4.1), these variables could not be reliably modelled together as predictors in our structural equation model. Therefore, a composite variable was constructed as described above, combining plant diversity, above- and belowground biomass in a PCA. The Plant Diversity and Biomass component (PC1) accounted for $94.9 \%$ of the total variation and each individual variable was loaded relatively equally (figs. S4.1 and S4.2). The Plant Diversity and Biomass composite variable was clearly defined as the higher the PC1 score, the greater the plant diversity, above- and belowground biomass (fig. S4.2). 
Multilevel path modelling Because of the hierarchical layout of the sampling design, whereby sites were split between two different landscapes, as well as a need for the flexibility to test for interactions between land use and abiotic variables, multilevel generalized path analysis (a form of structural equation modelling) was employed (24). To construct such a model, first the basis set $\boldsymbol{B}_{U}$ of independence claims that are implied by a directed acyclic causal diagram (i.e., a unidirectional box-and-arrow diagram) was identified. To do so, all possible relationships between predictor and response variables were identified. Specifically, we allowed for direct and interactive effects between land use and all abiotic variables on biotic response variables for ecologically meaningful relationships (see fig. S4.3). Additionally, we only permitted likely bottom-up trophic effects among biotic variables. Although top-down effects are also likely to play a role in structuring multitrophic communities, here we specifically test for bottom-up effects because we expected the impacts of land-use intensification to be most severe on plant and microbial communities (55). $\boldsymbol{B}_{U}$ expresses the full set of independence claims (i.e., pairs of variables in the acyclic model with no arrow between them) and implies dependence claims (pairs of variables in the model with a causal arrow joining them). These claims describe the $p_{i}$ probability that variable pairs $\left(X_{i}, X_{j}\right)$ are independent, conditional on the variable set $\boldsymbol{Z}$, which are direct causes of either $X_{i}$ or $X_{j}$. The probabilities $p_{i}$ for each of the $k$ independence claims in $\boldsymbol{B}_{U}$ were identified using linear mixed effects models. The combined $p_{i}$ of the full model was calculated as

$$
C=-2 \sum_{i=1}^{k} \ln \left(p_{i}\right)
$$

and the $C$ value was then compared to a chi-square $\left(\chi^{2}\right)$ distribution with $2 k$ degrees of freedom (24). The resulting probability, $P$, indicates whether the data depart significantly from what would be expected under such a causal model (24). A model is rejected if the resulting $P$-value is smaller than the specified $\alpha$-level (in this case $\alpha=0.05$ ). Therefore, if $P>0.05$ the causal model is not rejected and provides a good fit to the data.

Linear mixed effects models with random intercepts were fitted using the 'nlme' package in R 3.0.1 (53), with 'landscape' (i.e., Bukit Duabelas and Harapan locations) specified as a random effect. All variables were mean-centred by subtracting the mean of a given variable from each value of that variable. Assumptions of normality were tested by inspecting the variance structure of each model. As all predictors in the model were mean-centred, unstandardised path coefficients could be interpreted as the degree of change in the response variable for a given unit change in the predictor. However, interaction terms are interpreted differently whereby the coefficient indicates the amount of change in the slope of the regression of the response variable against a predictor (in this case, land use) following a unit change in the other interacting predictor variable.

Model fit was assessed using the procedure for calculating $R^{2}$ values for generalized linear mixed effects models as outlined by Nakagawa and Schielzeth (56). This directly indicates the proportion of total variation of endogenous variables explained by all significant predictors and their conditioning variables. Standardised coefficients, or $z$-scores, were calculated to assess relative effect sizes of each predictor on endogenous variables by dividing the mean-centred variables by twice their standard deviation (57) so that effects were expressed in units of standard deviation. As such, standardised effects can be directly compared and thus indicate the relative importance of each path. 


\section{Supplementary References}

28. B. Margono, P. Potapov, Primary forest cover loss in Indonesia over 2000-2012, Nat. Clim. Chang. 4, 730-735 (2014).

29. S. Mumme, M. Jochum, U. Brose, N. F. Haneda, A. D. Barnes, Functional diversity and stability of litter-invertebrate communities following land-use change in Sumatra, Indonesia, Biol. Conserv. 191, 750-758 (2015).

30. G. Gee, J. Bauder, in Methods of soil analysis, Part 1, A. Klute, Ed. (Soil Science Society of America, Madison, WI, 1986), pp. 383-411.

31. G. Blake, K. Hartge, in Methods of soil analysis, Part 1, A. Klute, Ed. (Soil Science Society of America, Madison, WI, 1986), pp. 363-375.

32. J. Chave et al., Tree allometry and improved estimation of carbon stocks and balance in tropical forests, Oecologia 145, 87-99 (2005).

33. J. B. Wauters, S. Coudert, E. Grallien, M. Jonard, Q. Ponette, Carbon stock in rubber tree plantations in Western Ghana and Mato Grosso (Brazil), For. Ecol. Manage. 255, 2347-2361 (2008).

34. N. Asari, M. N. Suratman, J. Jaafar, M. M. Khalid, Estimation of above ground biomass for oil palm plantations using allometric equations., Int. Proc. Chem. Biol. Environ. Eng. 58, 110-114 (2013).

35. S. A. Schnitzer, S. J. DeWalt, J. Chave, Censusing and measuring lianas: a quantitative comparison of the common methods, Biotropica 38, 581-591 (2006).

36. K. Niiyama et al., Estimation of root biomass based on excavation of individual root systems in a primary dipterocarp forest in Pasoh Forest Reserve, Peninsular Malaysia, J. Trop. Ecol. 26, 271 (2010).

37. Syahrinudin, in Ecology and Development Series No. 28, (Cuvillier Verlag, Göttingen, 2005).

38. S. J. Grove, Extent and composition of dead wood in Australian lowland tropical rainforest with different management histories, For. Ecol. Manage. 154, 35-53 (2001).

39. J. B. Kauffman, D. Donato, Protocols for the measurement, monitoring and reporting of structure, biomass and carbon stocks in mangrove forests (Center for International Forestry Research (CIFOR), Bogor, Indonesia, 2012).

40. P. C. Brookes, A. Landman, G. Pruden, D. S. Jenkinson, Chloroform fumigation and the release of soil nitrogen: a rapid direct extraction method to measure microbial biomass nitrogen in soil, Soil Biol. Biochem. 17, 837-842 (1985).

41. E. A. Davidson, R. W. Eckert, S. C. Hart, M. K. Firestone, Direct extraction of microbial biomass nitrogen from forest and grassland soils of California, Soil Biol. Biochem. 21, 773-778 (1989).

42. D. Schneider, G. Arp, A. Reimer, J. Reitner, R. Daniel, Phylogenetic analysis of a microbialiteforming microbial mat from a hypersaline lake of the Kiritimati Atoll, Central Pacific, PLoS 
One 8 (2013), doi:10.1371/journal.pone.0066662.

43. J. G. Caporaso et al., QIIME allows analysis of high-throughput community sequencing data, Nat. Methods 7, 335-336 (2010).

44. L. Bragg, G. Stone, M. Imelfort, P. Hugenholtz, G. W. Tyson, Fast, accurate error-correction of amplicon pyrosequences using Acacia, Nat. Methods 9, 425-426 (2012).

45. R. C. Edgar, B. J. Haas, J. C. Clemente, C. Quince, R. Knight, UCHIME improves sensitivity and speed of chimera detection, Bioinformatics 27, 2194-2200 (2011).

46. N. Larsen et al., The ribosomal database project., Nucleic Acids Res. 21, 3021-3023 (1993).

47. C. Quast et al., The SILVA ribosomal RNA gene database project: improved data processing and web-based tools, Nucleic Acids Res. , gks1219 (2012).

48. A. Wielgoss, T. Tscharntke, D. Buchori, B. Fiala, Y. Clough, Temperature and a dominant dolichoderine ant species affect ant diversity in Indonesian cacao plantations, Agric. Ecosyst. Environ. 135, 253-259 (2010).

49. T. M. Fayle, K. M. Yusah, Y. Hashimoto, Key to the ant genera of Borneo in English and Malay (2014).

50. G. Gowing, H. F. Recher, Length-weight relationships for invertebrates from forests in southeastern New South Wales, Austral Ecol. 9, 5-8 (1984).

51. J. MacKinnon, K. Phillips, A field guide to the birds of Borneo, Sumatra, Java and Bali: the greater Sunda Islands (Oxford University Press, 1993).

52. H. Wilman et al., EltonTraits 1.0: Species-level foraging attributes of the world's birds and mammals, Ecology 95, 2027 (2014).

53. R Core Team, R: a language and environment for statistical computing. http://www.Rproject.org/ (2015) (available at http://www.r-project.org).

54. M. D. Swaine, Rainfall and soil fertility as factors limiting forest species distributions in Ghana, J. Ecol. 84, 419-428 (1996).

55. F. S. Chapin III et al., Consequences of changing biodiversity, Nature 405, 234-242 (2000).

56. S. Nakagawa, H. Schielzeth, A general and simple method for obtaining R2 from generalized linear mixed-effects models, Methods Ecol. Evol. 4, 133-142 (2013).

57. A. Gelman, Scaling regression inputs by dividing by two standard deviations, Stat. Med. 27, 2865-2873 (2008). 
Table S4.1. Full list of measured biotic variables organized into major taxonomic groups. Values are means of biomass and diversity (species richness) within each land-use system.

\begin{tabular}{|c|c|c|c|c|c|}
\hline Biotic variable & Unit & Forest & Jungle rubber & Rubber & Oil palm \\
\hline \multicolumn{6}{|l|}{ Plants } \\
\hline $\begin{array}{l}\text { aboveground } \\
\text { biomass }\end{array}$ & $\mathrm{Mg} \mathrm{ha}^{-1}$ & 321.42 & 115.28 & 61.06 & 42.30 \\
\hline $\begin{array}{l}\text { belowground } \\
\text { biomass }\end{array}$ & $\mathrm{Mg} \mathrm{ha}^{-1}$ & 70.28 & 37.46 & 21.49 & 18.92 \\
\hline diversity & $\begin{array}{l}\text { species richness } \\
\text { (OTU) }\end{array}$ & 274.50 & 158.75 & 61.63 & 71.13 \\
\hline
\end{tabular}

\section{Microbes}

$\begin{array}{llrrrr}\text { biomass } & \text { mg N kg-1 } & 781.04 & 750.03 & 511.00 & 509.85 \\ \text { archaeal diversity } & \begin{array}{l}\text { species richness } \\ \text { (OTU) }\end{array} & 123.81 & 112.95 & 105.84 & 114.56 \\ & & & & \\ \text { bacterial diversity } & \begin{array}{l}\text { species richness } \\ \text { (OTU) }\end{array} & 957.10 & 1052.08 & 1258.7 & 1373.7 \\ & & & & 1 & 7\end{array}$

\section{Litter \\ invertebrates}

detritivore biomass

$\operatorname{mg} 3 \mathrm{~m}^{-2}$

103.89

55.79

50.39

35.24

detritivore

species richness

diversity

(OTU)

22.50

23.63

17.63

13.38

herbivore biomass

$\mathrm{mg} 3 \mathrm{~m}^{-2}$

9.29

13.94

31.90

7.63

herbivore diversity

species richness

(OTU)

3.88

5.75

7.88

4.38

omnivore biomass

$\mathrm{mg} 3 \mathrm{~m}^{-2}$

62.93

49.45

75.08

76.65

omnivore diversity

species richness

(OTU)

26.63

18.75

18.88

14.50

predator biomass

$\mathrm{mg} 3 \mathrm{~m}^{-2}$

166.37

97.61

95.41

42.40

predator diversity

species richness (OTU)

41.25

33.63

29.88

19.38 


\section{Arboreal ants}

$\begin{array}{llcrrr}\text { biomass } & \text { mg per bate station } & 8.89 & 10.65 & 10.61 & 32.07 \\ & \mathrm{hr}^{-1} & & & & \\ \text { diversity } & \text { species richness } & 9.88 & 8.11 & 13.38 & 13.33\end{array}$

\section{Birds}

\begin{tabular}{llrrrr} 
herbivore biomass & g per site & 2930.2 & 517.39 & 166.18 & 461.91 \\
& & 8 & & & 4.00 \\
herbivore diversity & species richness & 2.75 & 2.88 & 2.50 & 33.25 \\
omnivore biomass & g per site & 136.33 & 25.01 & 41.64 & 0.25 \\
omnivore diversity & species richness & 1.25 & 0.5 & 0.5 & 162.39 \\
predator biomass & g per site & 453.78 & 255.87 & 196.60 & 2.00 \\
predator diversity & species richness & 4.75 & 3.38 & 2.38 & \\
\hline
\end{tabular}


Table S4.2. Model parameters for all dependence claims in the multilevel path model. Unstandardised coefficients and their respective standard errors are taken from the initial model with mean-centred variables. The $z$-scores column gives coefficients from the path model after being re-run with standardised values (mean-centred variables divided by twice their standard deviation). Marginal $R^{2}$ values indicate total proportion of variance explained by all significant predictors and their conditioning variables in the significant mixed effects models.

\begin{tabular}{|c|c|c|c|c|c|c|}
\hline $\begin{array}{l}\text { response } \\
\text { variable }\end{array}$ & fixed effects & $\begin{array}{l}\text { unstandardised } \\
\text { coefficients }\end{array}$ & $\begin{array}{l}\text { std. } \\
\text { error }\end{array}$ & z-score & p-value & $\begin{array}{l}\text { marginal } \\
\quad \mathrm{R} 2\end{array}$ \\
\hline \multirow[t]{2}{*}{ Div.Mass. } & land use & -4.090 & 0.180 & -1.194 & $<0.001$ & 0.955 \\
\hline & land use*Nut.Avail. & -0.315 & 0.095 & -0.305 & 0.028 & \\
\hline \multirow[t]{3}{*}{ microbial Mass. } & land use & -0.199 & 0.081 & -0.563 & 0.002 & 0.477 \\
\hline & Nut.Avail. & -0.053 & 0.014 & -0.496 & $<0.001$ & \\
\hline & $\begin{array}{l}\text { land use*soil } \\
\text { Org.Mat. }\end{array}$ & 0.084 & 0.055 & 0.669 & 0.019 & \\
\hline \multirow[t]{2}{*}{ microbial Div. } & land use & 662.743 & 136.534 & 1.483 & $<0.001$ & 0.538 \\
\hline & microclimatic Var. & -86.477 & 36.765 & -0.572 & 0.027 & \\
\hline Arb.Ant Mass. & land use & 0.635 & 0.113 & 0.952 & $<0.001$ & 0.535 \\
\hline Arb.Ant Div. & land use & 3.546 & 1.580 & 0.445 & 0.004 & 0.305 \\
\hline Inv.Herb.Mass. & plant Div.Mass. & -0.727 & 0.327 & -2.068 & 0.038 & 0.316 \\
\hline \multirow[t]{2}{*}{ Inv.Herb.Div. } & land use & -1.501 & 0.531 & -2.568 & 0.019 & 0.452 \\
\hline & plant Div.Mass. & -0.308 & 0.141 & -1.806 & 0.041 & \\
\hline Inv.Detr.Mass. & soil Org.Mat. & 0.220 & 0.061 & 0.559 & 0.001 & 0.302 \\
\hline \multirow[t]{3}{*}{ Inv.Detr.Div. } & land use & -1.169 & 0.283 & -3.149 & $<0.001$ & 0.534 \\
\hline & plant Div.Mass. & -0.208 & 0.086 & -1.921 & 0.026 & \\
\hline & microbial Div. & 0.0005 & 0.0001 & 0.598 & 0.016 & \\
\hline \multirow[t]{2}{*}{ Inv.Omni.Mass. } & land use & -0.445 & 0.235 & -0.511 & $<0.001$ & 0.784 \\
\hline & microclimatic Var. & -0.155 & 0.066 & -0.524 & 0.033 & \\
\hline
\end{tabular}




\begin{tabular}{|c|c|c|c|c|c|c|}
\hline & land use*Nut.Avail. & 0.328 & 0.084 & 1.250 & 0.003 & \\
\hline & $\begin{array}{l}\text { land use*soil } \\
\text { Org.Mat. }\end{array}$ & 0.740 & 0.170 & 2.384 & 0.002 & \\
\hline \multirow[t]{3}{*}{ Inv.Omni.Div. } & land use & -0.213 & 0.085 & -0.601 & 0.073 & 0.720 \\
\hline & Inv.Herb.Div. & 0.293 & 0.082 & 0.827 & 0.002 & \\
\hline & $\begin{array}{l}\text { land use*soil } \\
\text { Org.Mat. }\end{array}$ & -0.125 & 0.064 & -0.351 & 0.009 & \\
\hline Inv.Pred.Mass. & land use & -0.706 & 0.167 & -0.860 & 0.002 & 0.383 \\
\hline \multirow[t]{2}{*}{ Inv.Pred.Div. } & Inv.Detr.Div. & 0.757 & 0.180 & 0.572 & $<0.001$ & 0.681 \\
\hline & Inv.Omni.Div. & 0.713 & 0.256 & 0.514 & 0.012 & \\
\hline \multirow[t]{3}{*}{ bird Pred.Mass. } & microclimatic Var. & -129.419 & 33.159 & -0.755 & $<0.001$ & 0.478 \\
\hline & Arb. ant Mass. & 538.736 & 190.126 & 0.709 & 0.010 & \\
\hline & Inv.Herb.Div. & 334.541 & 160.412 & 0.386 & 0.049 & \\
\hline \multirow[t]{4}{*}{ bird Pred.Div. } & microclimatic Var. & -0.075 & 0.025 & -0.484 & 0.007 & 0.589 \\
\hline & Inv.Pred.Mass. & 0.306 & 0.102 & 0.507 & 0.009 & \\
\hline & Inv.Pred.Div. & -0.701 & 0.261 & -0.747 & 0.013 & \\
\hline & Inv.Herb.Div. & 0.407 & 0.124 & 0.516 & 0.004 & \\
\hline
\end{tabular}



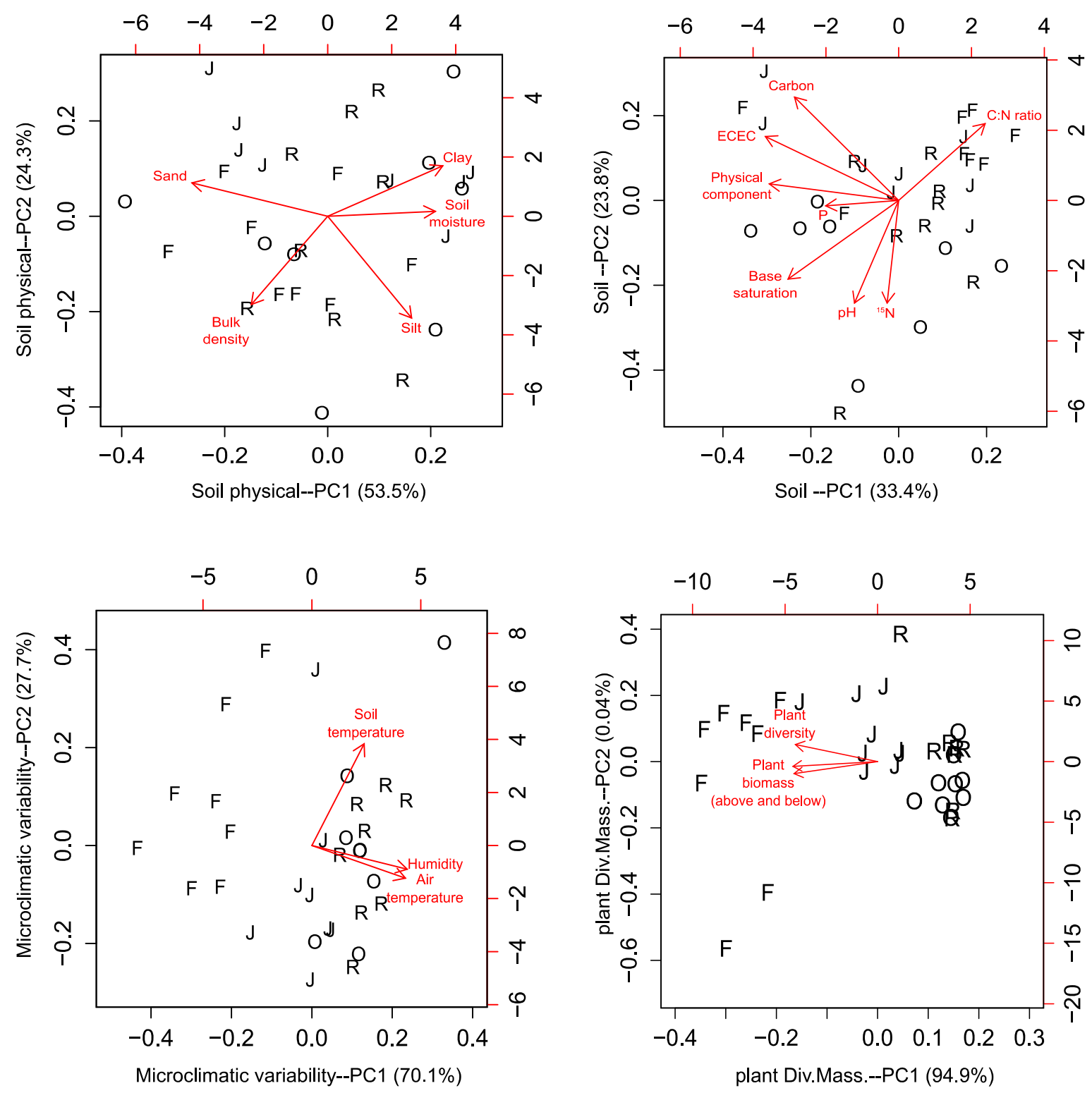

Fig. S4.1. Series of principal component analysis (PCA) plots of each of the composited variables (row 1: soil physical component, and combined soil physical and biochemical component; row 2: microclimatic component, and plant diversity and biomass component) used in the multilevel path model. The eight sites of the four land-use types are plotted along PCA axes 1 and 2 (proportion of explained variance in parentheses) with red vectors (parameters included in PCA composite) illustrating factor loadings. Land-use systems are forest (F), jungle rubber (J), rubber monoculture $(\mathrm{R})$, and oil palm monoculture $(0)$. 

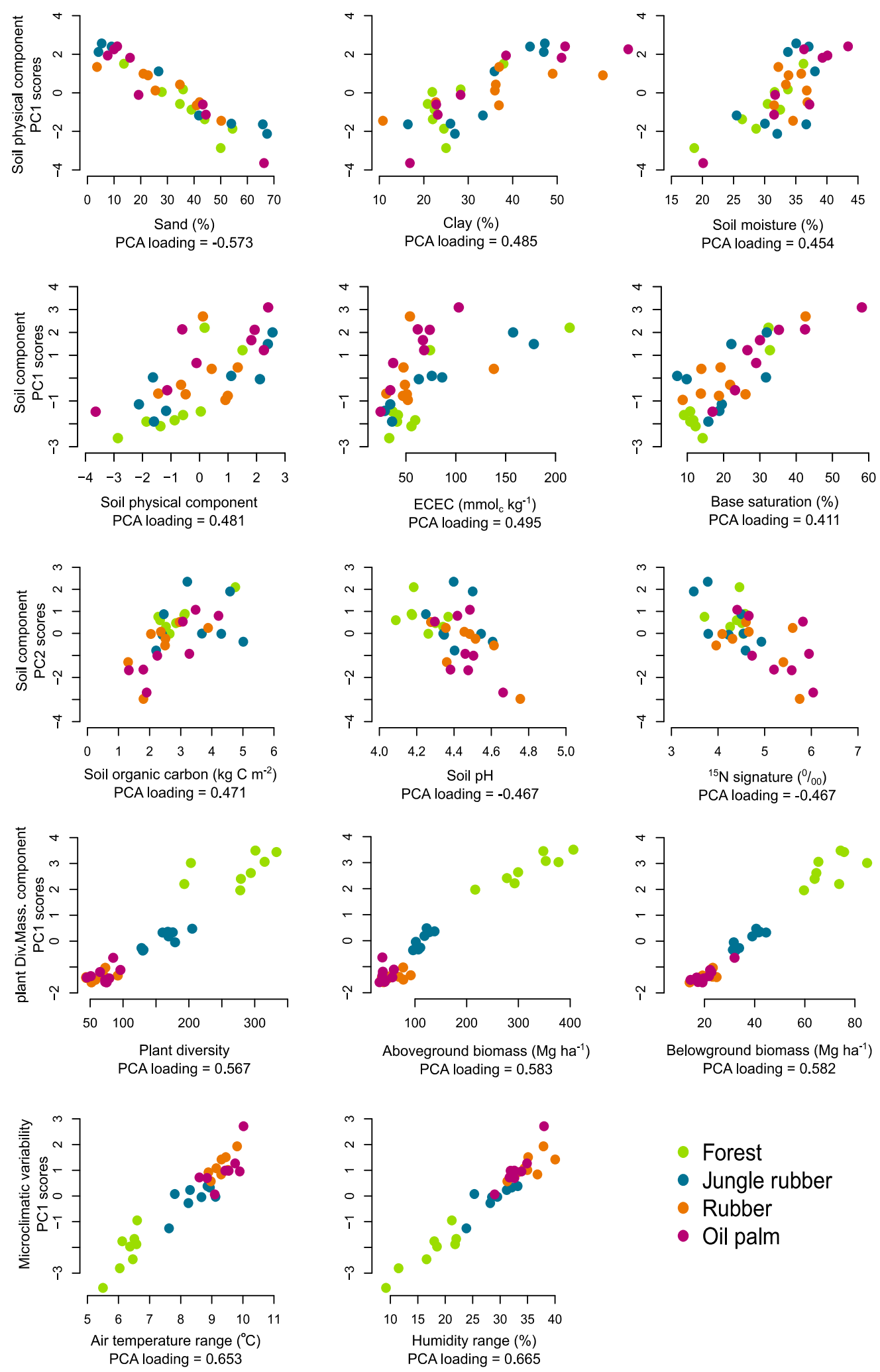

Fig. S4.2. Relationships among the PCA scores for each composited variable and the parameters incorporated within the composited variables, which have PCA loadings of $\geq 0.400$. Data points represent the eight sites of the four land-use types. 


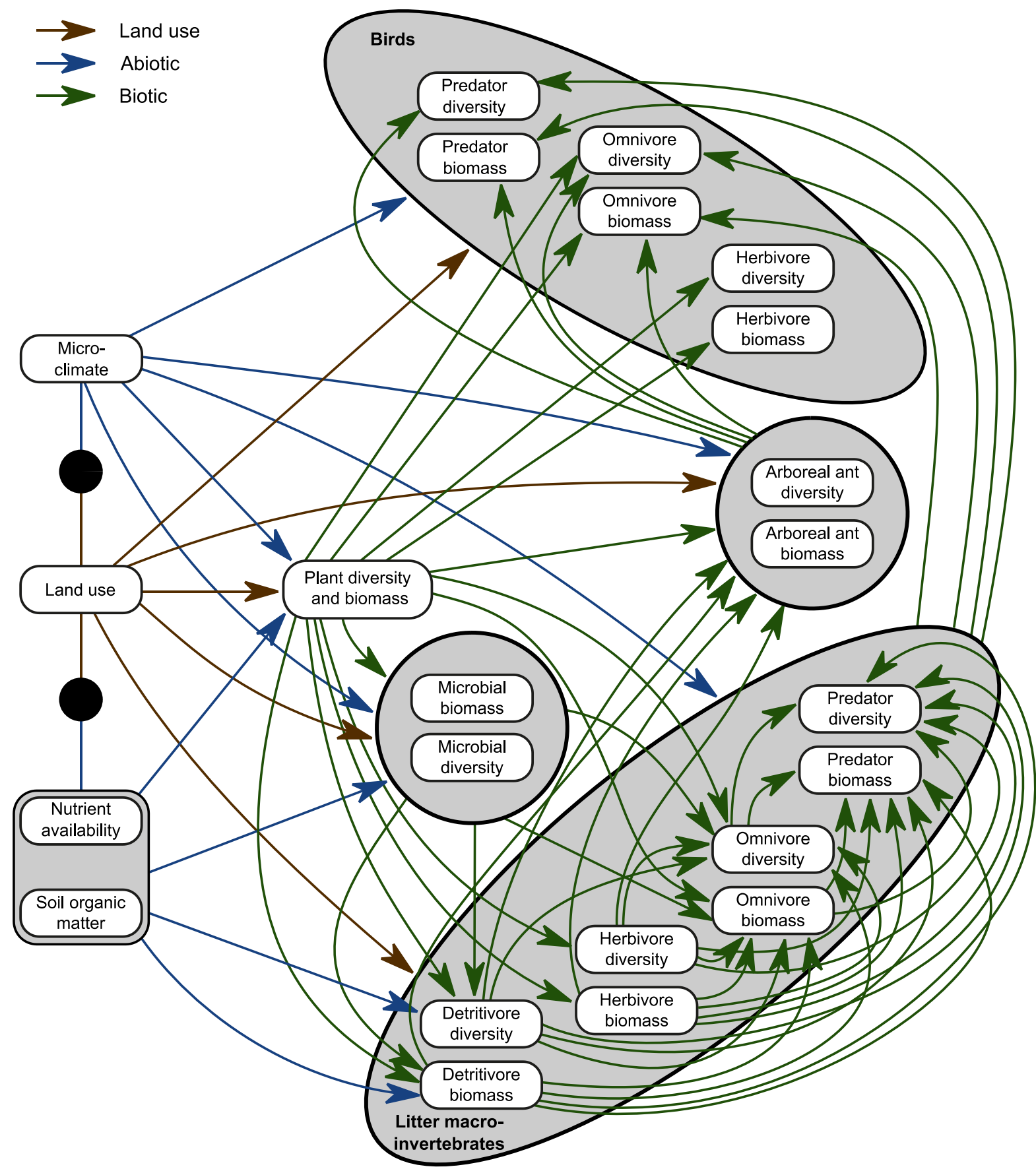

Fig. S4.3. Diagram exhibiting all possible independence claims that were tested within the multilevel path model. Arrows leading from and to whole variable groups (variables enclosed within grey polygons) indicate that all variables within these groups are either respective predictor or response variables in such indicated models (for visual simplification). Black circular nodes between land-use change and the environmental variables indicate where interaction terms were also included in the independence claims. 
Plants

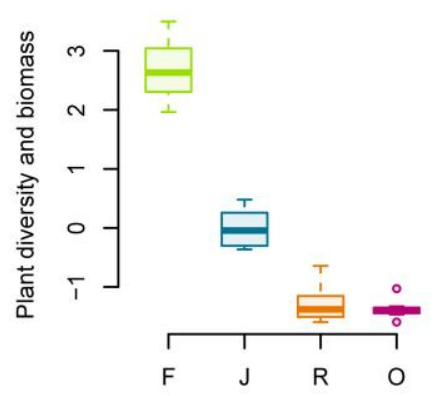

Litter invertebrates

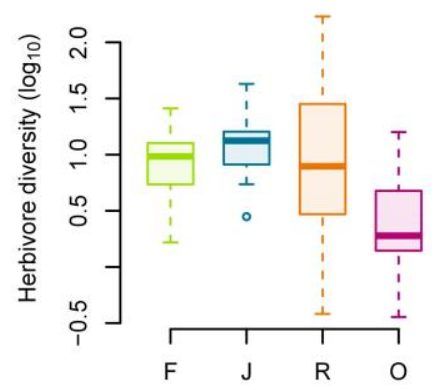

Litter invertebrates

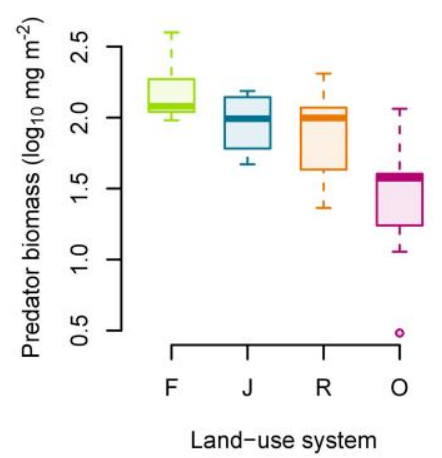

Soil microbes

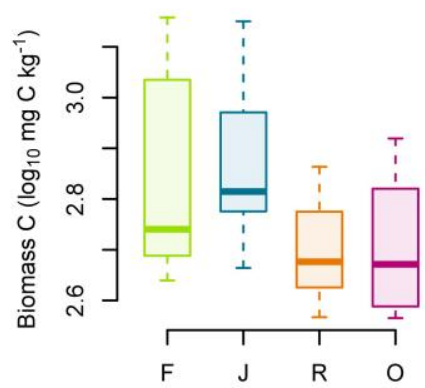

Litter invertebrates

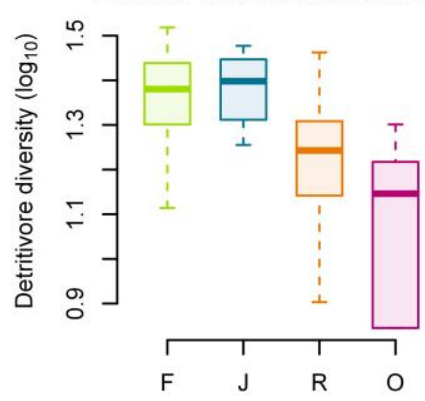

Arboreal ants

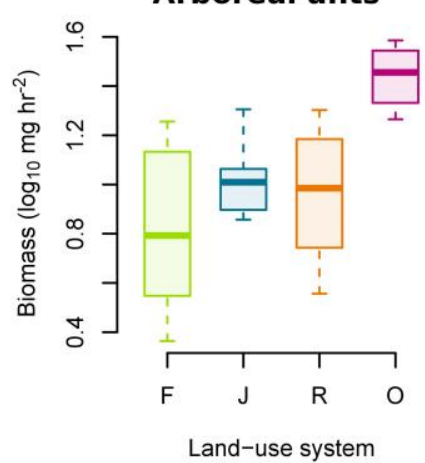

Soil microbes

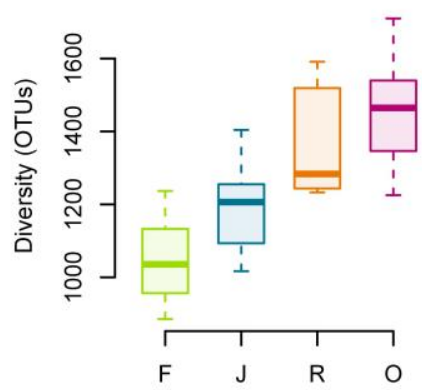

Litter invertebrates

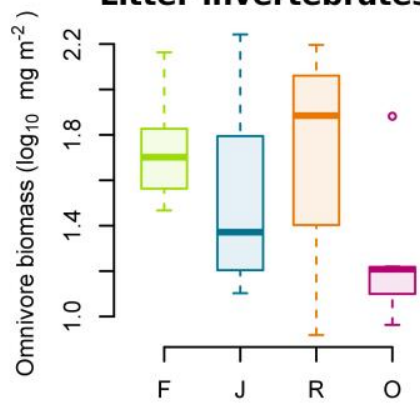

Arboreal ants

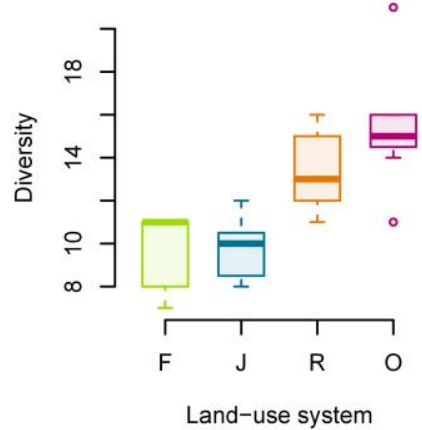

Fig. S4.4. Box plots of all biotic variables across the four land-use systems that responded significantly to land-use change within the multilevel path model. Land-use systems are forest (F), jungle rubber (J), rubber monoculture (R), and oil palm monoculture (O). 


$\rightarrow$ Forest
$\rightarrow$ Jungle rubber
$\rightarrow$ Rubber
$\rightarrow$ Oil palm
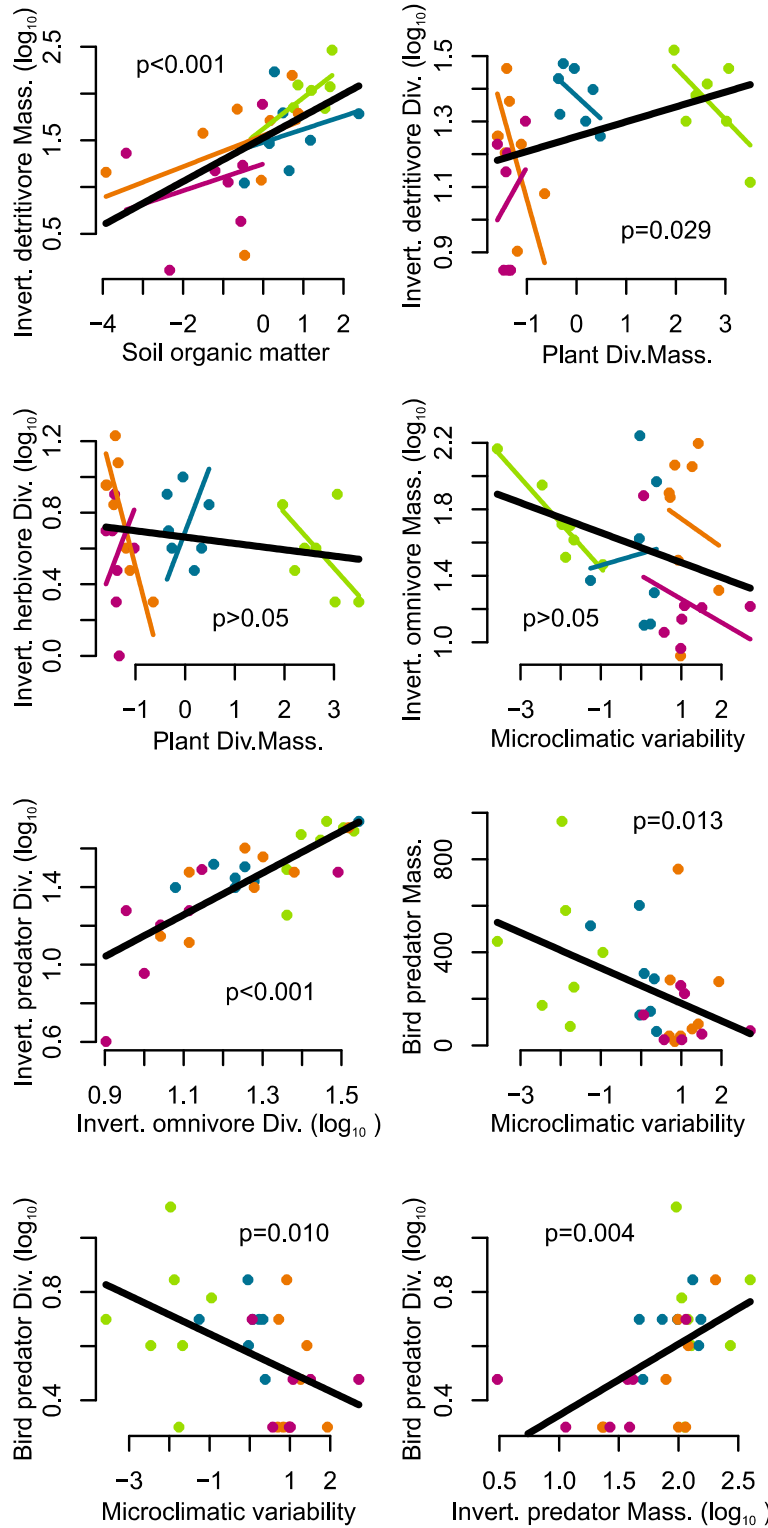
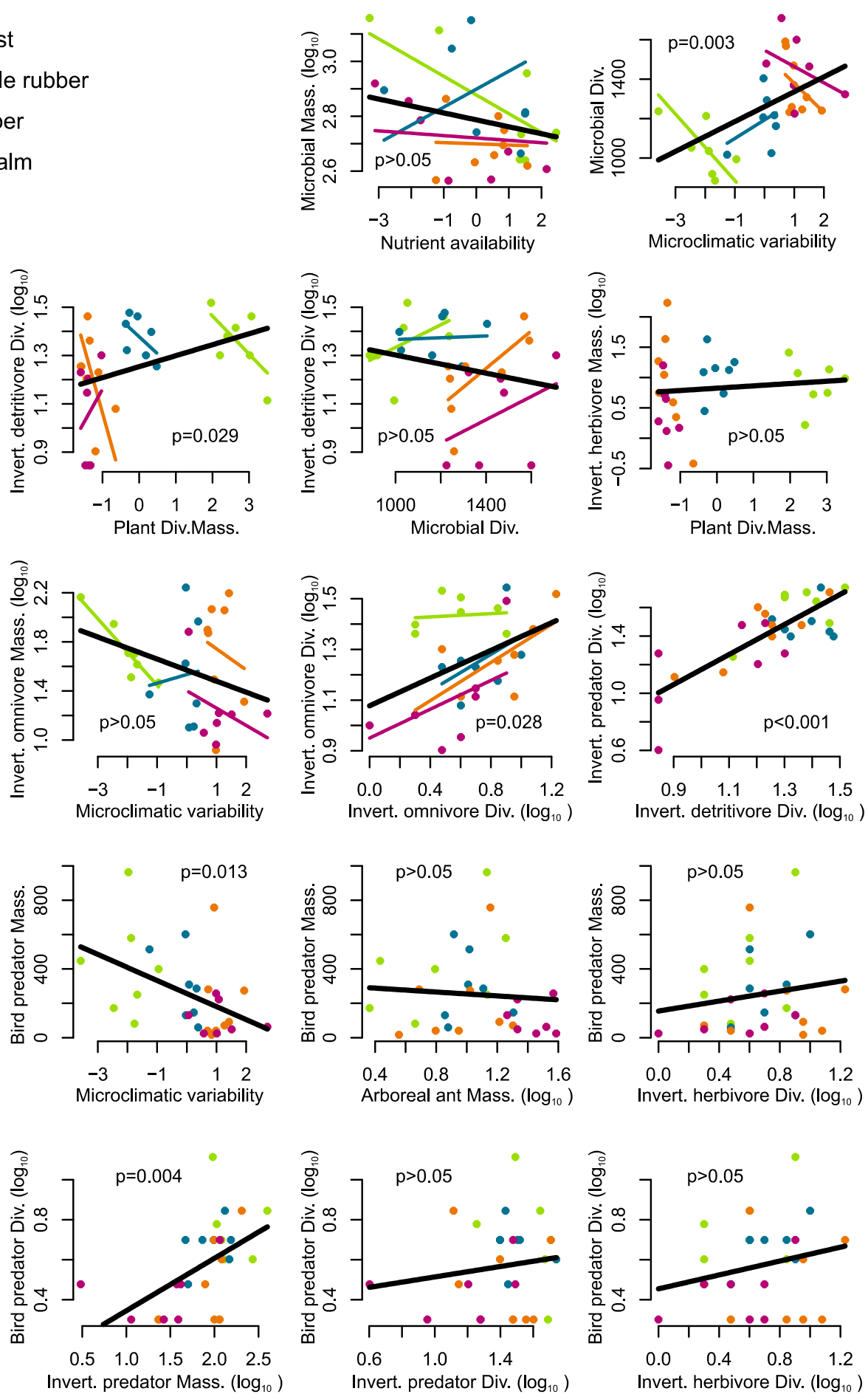

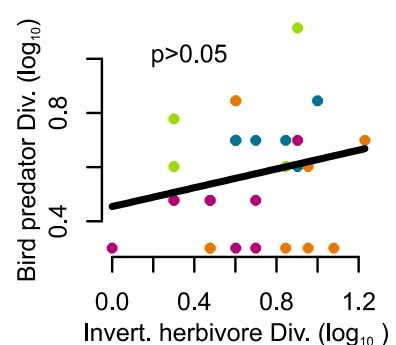

Fig. S4.5. Pairwise relationships among all response and predictor variables where significant direct effects were detected within the multilevel path model. Points are coloured according to land-use system, with their respective coloured model fits plotted where land-use change was found to have a significant effect in the multilevel path model. Model fits for the overall pairwise relationships (tested in isolation, excluding all conditioning variables that were included in the complete path model) are shown by a black line, with their respective p-values indicated on each panel. 'Div.' and 'Mass.' stand for diversity and biomass, respectively. 


\section{Chapter 5}

\section{Synthesis}

\subsection{Soil-N cycling responses to land-use conversion. Key findings}

Clay content which controlled soil fertility, subsequently influenced soil-N cycling rates in this converted landscape on highly weathered Acrisol soils. The clay Acrisol soil exhibited higher soil-N cycling pools and rates, as well as more pronounced changes in soil-N cycling pools and rates across land-use types compared to the loam Acrisol soil. In the clay Acrisol landscape, soil-N availability was highest in the forest and jungle rubber, lowest in the unfertilized rubber plantations and intermediate in the fertilized oil palm plantations (see Fig. 5.1A-D below).

\section{Implications on $\mathbf{N}$ losses}

The processes comprising the internal soil nitrogen $(\mathrm{N})$ cycle (see Fig. 1.1; pg. 17) are important to quantify in order to understand how $\mathrm{N}$ is cycled within a particular system. As previously discussed in Chapters 1 and 2, the potential for $\mathrm{N}$ to be lost either via nutrient leaching or $\mathrm{N}$-oxide trace gas emissions is high when forests are converted to agricultural land uses due to the disruption in the efficient cycling of soil $\mathrm{N}$ in undisturbed forest ecosystems. Such disruption in the internal soil- $\mathrm{N}$ cycle can be assessed by comparing the internal soil-N cycling rates of the converted land uses with the reference land use(s). Furthermore, incorporating soil-N cycling rates and $\mathrm{N}$ pools with ancillary studies on $\mathrm{N}$ leaching (Kurniawan et al. unpublished data) and N-oxide emissions (Hassler et al. unpublished data) measured in the same 32 plots, generates a more holistic picture of the general soil-N cycle in this converted landscape.

The similar rates of ammonium $\left(\mathrm{NH}_{4}{ }^{+}\right)$production and retention in the lowland forest and jungle rubber soils signified tightly coupled $\mathrm{NH}_{4}{ }^{+}$cycling in these land uses. Efficient cycling of the most prevalent form of $\mathrm{N}$ in these systems led to lower leaching losses (Fig. 5.1A). Soil texture also 
influenced $\mathrm{N}$ leaching in these Acrisol soils; with the higher leaching losses from the loam Acrisol soils compared to the clay Acrisol soils. This is due to both the ability of clay soils to retain nutrients, as well as the larger pore spaces in the loam than clay soils that would allow for more direct rather than tortuous water movement (Hillel 1982). Nitrate $\left(\mathrm{NO}_{3}^{-}\right)$is often the most common form of $\mathrm{N}$ lost via groundwater leaching due to its negative charge and inability to bind to negatively charged exchange sites of soil clay fractions. Our rubber plantations, which exhibited the lowest $\mathrm{NO}_{3}-$ pools and production rates as well as the highest rates of dissimilatory $\mathrm{NO}_{3}{ }^{-}$reduction to $\mathrm{NH}_{4}{ }^{+}$(DNRA), also experienced the lowest $\mathrm{NO}_{3}$ - leaching losses (Fig. 5.1B). Some of the highest leaching losses were found in the oil palm plantations in the loam Acrisol soil (Fig. 5.1C). High leaching of $\mathrm{NO}_{3}{ }^{-}$and to some extent $\mathrm{NH}_{4}{ }^{+}$in oil palm was due to $\mathrm{N}$ fertilization, which also increased gross soil- $\mathrm{N}$ cycling rates. Several conclusions can be drawn by comparing the gross rates of soil-N cycling with $\mathrm{N}$ leaching losses. First, where gross rates of soil-N cycling were low and soil $\mathrm{N}$ availability was low, $\mathrm{N}$ leaching losses were also low. Second, increased gross soil-N cycling rates and soil $\mathrm{N}$ availability may not always lead to higher $\mathrm{N}$ leaching losses, if $\mathrm{N}$ retention processes keep pace with increased mineral $\mathrm{N}$ production processes. Therefore, in systems with high soil $\mathrm{N}$ availability it is necessary to quantify gross $\mathrm{N}$ production and retention mechanisms. As we found that comparable rates of mineral $\mathrm{N}$ production and retention may lead to less nutrient leaching and higher rates of mineral $\mathrm{N}$ production compared to its retention rates, typically associated with agricultural management practices (i.e., fertilization), can lead to higher N leaching losses.

Although preliminary results from the ancillary study on soil N-oxide emissions (Hassler et al. unpublished data) did not reveal significant land-use change effects on soil nitrous oxide $\left(\mathrm{N}_{2} \mathrm{O}\right)$ emissions, some trends in the data were apparent. In general, land uses with the highest microbial biomass pools tended to show higher soil $\mathrm{N}_{2} \mathrm{O}$ emissions (i.e., clay Acrisol forest sites; Fig. 5.1A). Soil microbial communities are responsible for producing these $\mathrm{N}$ trace gases during $\mathrm{N}$ transformation reactions. Therefore, it is not wholly unexpected to find higher $\mathrm{N}$ trace gas emissions from our reference land uses, which also exhibited high microbial biomass pools. Fertilization has also been found to increase soil $\mathrm{N}$ trace gas emissions (Veldkamp et al. 2008). The lowest $\mathrm{N}$ trace gas emissions were found in our rubber plantations, especially in the clay Acrisol soils (Fig. 5.1B). Both the low soil $\mathrm{N}$ availability and the low microbial biomass pools found in our unfertilized rubber plantations may have contributed to reduced soil $\mathrm{N}_{2} \mathrm{O}$ emissions from this land use. Nitrogen fertilization in oil palm plantations increased gross soil- $\mathrm{N}$ cycling rates and soil $\mathrm{N}$ availability, as well as the production of $\mathrm{N}_{2} \mathrm{O}$ from these systems. This further adds to the higher amount of $\mathrm{N}$ lost from our oil palm plantations (Fig. 5.1C). These results indicate that the size of the microbial 
biomass pool and soil $\mathrm{N}$ availability, as well as associated agricultural management practices strongly influence $\mathrm{N}$ trace gas emissions from our land uses.

The $\mathrm{N}$ lost from our land-use systems either through $\mathrm{N}$ trace gas emissions or leaching has potential detrimental effects on other ecosystem components (e.g., air and water). Fertilization can replenish a majority of the $\mathrm{N}$ lost from these systems. However, as illustrated by previous studies, $\mathrm{N}$ added to these highly weathered soils decreases fertility of other macronutrients (e.g., base cations) and overtime can diminish soil $\mathrm{N}$ availability. This leads to a dependence on fertilization, which is neither economically nor environmentally sustainable. Therefore, future research should focus on more sustainable fertilization practices that can not only benefit our smallholder farmers economically, but can also generate optimum agricultural yield with the least detrimental impacts on soil sustainability, water and air quality. 

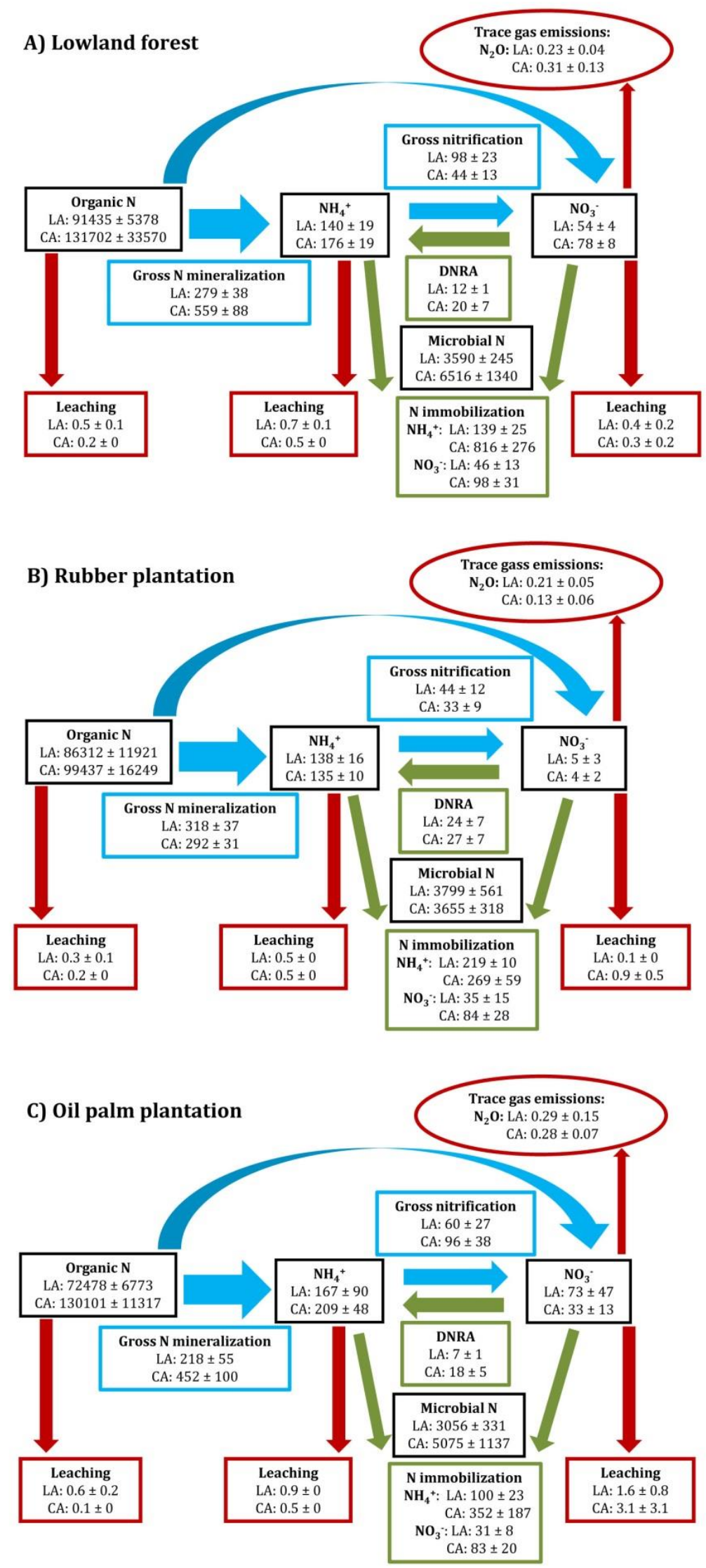

Figure 5.1. Soil-N cycling rates and soil $N$ pools separated by soil landscape (LA: loam Acrisol and CA: clay Acrisol) in the A) lowland forest, B) rubber plantations and C) oil palm plantations. Jungle rubber was generally comparable with the lowland forest in soil- $\mathrm{N}$ cycling rates and $\mathrm{N}$ pools, and thus is excluded from this figure. Black boxes represent soil $\mathrm{N}$ pools, expressed in $\mathrm{mg} \mathrm{N} \mathrm{m}^{-2}$. Blue boxes and arrows represent mineral $\mathrm{N}$ production rates in the soil, expressed in $\mathrm{mg} \mathrm{N} \mathrm{m}^{-2}$ day $^{-1}$. Green boxes and arrows represent $\mathrm{N}$ retention rates in the soil, expressed in $\mathrm{mg} \mathrm{N} \mathrm{m}^{-2}$ day $^{-1}$. Red boxes and arrows represent $\mathrm{N}$ losses from the soil, expressed in $\mathrm{mg} \mathrm{N} \mathrm{m}^{-2}$ day-1. 


\subsection{Spatial variability surpasses land-use change effects on soil biochemical properties}

\section{Key findings}

Clay content affected soil fertility at all depths within our highly weathered Acrisol soils. The few soil biochemical characteristics (i.e., soil pH and base saturation) and soil nutrient stocks (i.e., extractable P) affected by land-use change were strongly influenced by the method of land-use conversion and the subsequent agricultural management practices. A majority of the soil biochemical characteristics and nutrient stocks were little affected by land-use change. The overall variance on many of our soil biochemical characteristics was mainly accounted by the variation amongst replicate plots rather than by land-use types. This demonstrates that in order to detect significant effects of land-use change on soil biochemical characteristics in our nested sampling experimental design, more replicate plots per land-use type should be sampled.

\section{Implications on number of replicates}

The results from our variance components analysis demonstrated the high spatial variability of soil biochemical characteristics within our study region. As well as the need to increase the number of replications per land-use type in our experimental design in order to detect significant land-use change effects on the soil biochemical characteristics of interest. To determine the optimal number of replications per land-use type per landscape, an one-way ANOVA power analysis was conducted on the means of an individual soil biochemical characteristic (i.e., either soil organic carbon (SOC), total N, effective cation exchange capacity (ECEC) or base saturation) for the top 0.5 $\mathrm{m}$ of each replicate plot, divided into eight groups (separated by land-use type per landscape). Sample sizes obtained from the power analysis represent the minimum number of replicate plots per group needed to detect significant land-use change effects on the tested soil biochemical parameter with an $\alpha=0.05$ and the default power of 80\% (Cohen 1992; Crawley 2007). In our present studies (see Chapters 2 and 3), we conducted our statistical analysis on the means of four replicate plots per land-use type per landscape. The soil biochemical characteristics with the highest variability in our study region were total $\mathrm{N}$ and ECEC, which required a minimum sample size of six replicate plots per group (Table 5.1). Soil organic carbon, which in general exhibits high spatial variability at the landscape scale (e.g., Powers and Schlesinger 2002; Chaplot et al. 2010), also required further sampling in our study region. However, base saturation required fewer replicates 
per group than originally sampled (Table 5.1). This is most likely due to the fixed scale in which base saturation is measured that ranges between $27-62 \%$ in our highly weathered Acrisol soils.

Table 5.1. Estimated minimum sample size per land-use type in each landscape needed to detect significant land-use change effects on soil biochemical parameters or processes.

\begin{tabular}{lc}
\hline $\begin{array}{l}\text { Soil biochemical parameter } \\
\text { or process }\end{array}$ & $\begin{array}{c}\text { Minimum sample size (n) } \\
\text { per land-use type } \mathbf{~}^{\mathbf{1}}\end{array}$ \\
\hline Soil organic carbon & 5 \\
Total N & 6 \\
Effective cation exchange capacity & 6 \\
Base saturation & 3 \\
\hline Gross N mineralization & 3 \\
Gross nitrification & 7 \\
Microbial biomass C & 4 \\
\hline Microbial biomass N & 4 \\
\hline
\end{tabular}

1Tested using one-way ANOVA power analysis with an $\alpha=0.05$ and a power of $80 \%$ (Cohen 1992; Crawley 1997).

Microbial pools and processes, such as those measured in Chapter 2, are also considered to have high spatial variability in soil (Parkin 1993). Because the microbial communities present in these land-use systems drive these processes, it can be assumed that the spatial variation of soil microbial pools and processes might potentially be higher than the variation of soil biochemical characteristics. To examine the spatial variability of microbial pools and processes in our study area, I used data from my first study (see Chapter 2) and conducted statistical power analysis on gross $\mathrm{N}$ mineralization and gross nitrification rates as well as on microbial biomass $\mathrm{C}$ and $\mathrm{N}$ pools as described above. In general, our sampling techniques for measuring pools of microbial biomass C and $\mathrm{N}$ were sufficient as the minimum number of samples estimated per group were the same as the number of replicates in that particular study $(n=4$; Table 5.1). The minimum number of replicates estimated to detect significant differences in gross $\mathrm{N}$ mineralization rates with land-use change was lower than what we originally sampled. This may be because $\mathrm{N}$ in the form of $\mathrm{NH}_{4}{ }^{+}$was in excess across our land uses, which potentially reduced the spatial variability of this $\mathrm{NH}_{4}{ }^{+}$related process. Nitrate concentrations were extremely variable across land uses and landscapes, which could explain the higher minimum number of replicate plots per group needed to determine significant land-use change effects on gross nitrification (Table 5.1). These results demonstrate that in our study region, soil biochemical characteristics exhibited higher spatial variability than microbial pools and processes. It is important to note that the results from this power analysis only represent the minimum sample size needed to detect significant differences between land-use types and are only valid for studies that are conducted across similar land-use types, topography and soil 
characteristics and have comparable sized replicate plots (50 m x $50 \mathrm{~m}$ ). However, these results may be useful in future studies focusing on soil properties within the framework of the CRC 990: EEFForTs project or other studies in the region that use a similar method of stratification (i.e., soil texture) at the landscape level within the experimental design.

\subsection{Tropical land use imposes direct and cascading impacts on biodiversity}

\section{Key findings}

Land-use change imposed direct effects on plants, belowground taxa at lower trophic levels (i.e., detritivores and herbivores) and arboreal ants, and many of the direct impacts of land-use change appeared to be modified by natural environmental variation (i.e., soil). Almost all land-use impacts at the highest trophic levels of invertebrates and birds were bottom-up controlled. This reveals that land-use change directly and indirectly drives large-scale ecological shifts, but that the effects detected at the highest trophic levels are mostly dependent on lower trophic-level organisms.

\section{Implications on ecosystem soil properties}

Within the multilevel path model, direct effects of soil properties (i.e., the Nutrient availability and Soil organic matter components) on the biotic variables were few and those direct effects that were present were weaker compared to the direct effects of land-use change (Fig. 4.2; pg. 81). The larger effect sizes of the direct land-use change effects within our path model could potentially be masking the relatively weaker effects of soil in our systems. This "overshadowing" by land-use change is not surprising; as we have learned from the first two studies in this thesis that land-use conversion impacts soil properties and processes to varying degrees (see Chapters 2 and 3). However, previous research also illustrates that ecosystem functions associated with soil properties (e.g., nutrient cycling and soil organic matter storage) are linked to plant and microbial communities (Cardinale et al. 2012; Wagg et al. 2014). Therefore, to explore the possible relationships between soil properties and processes and biotic variables, the two soil components within the path model, as well as a new $\mathrm{N}$ cycling composite variable calculated using principal components analysis (PCA), were modeled (LME; R Core Team 2014) with all biologically relevant biotic variables (i.e., with plants, microorganisms and litter invertebrates). Significant ( $\leq \leq 05)$ relationships were then plotted, illustrating both the overall trend as well as the trends within each land use, to examine these relationships further (Fig. 5.2 and 5.3; S5.2 Fig.). The N cycling 
component was created from net rates of $\mathrm{N}$ mineralization and nitrification measured from all 32 replicate plots and is described in detail in the Supplementary material below. Net N cycling rates provide an indication of plant available $\mathrm{N}$ in soil, which could potentially link plants and soil within our systems.

In general, more significant relationships between the soil components and organisms within the lowest trophic levels (i.e., plants and microbes) were observed. Only one significant effect between the soil components and the highest biologically relevant trophic level (i.e., litter invertebrates) was found ( $\mathrm{P} \leq 0.05$; S5.2 Fig.). The overall relationship between soil Nutrient availability and invertebrate omnivore diversity was negative, and this was mostly driven by the negative relationships present in the agricultural land uses. These results correspond to an ancillary study conducted within the CRC 990: EEFForTs project that also found decreases in invertebrate omnivore diversity in the agricultural land uses (Barnes et al. 2014). This shift in invertebrate omnivore communities with increasing soil nutrient availability could potentially be due to the negative effects of fertilization (a principal driver of the Nutrient availability component) on soil macrofauna (Bardgett and Cook 1998).

All three soil components exhibited significant effects with either plant biomass or diversity or both $(\mathrm{P} \leq 0.01-0.05$; Fig. 5.2A-E). However, the overall relationships between the soil components and plant biomass and diversity were predominantly driven by the underlying effects of land-use conversion (i.e., losses in either plant species and/or biomass coupled with cultivation). A majority of the trends present within the individual agricultural land uses demonstrated that these soil components possessed little to no relationship with plant biomass and diversity in our converted land uses (Fig. 5.2A-E). This trend was especially prevalent in all four land uses between Net $N$ cycling and plant biomass (Fig. 5.2C), illustrating that in our systems, N may not control plant productivity. The positive relationships between Nutrient availability and plant diversity, and to some extent Soil organic matter and plant diversity in the forest land use (Fig. 5.2D-E), reflect trends in previous research that found as ecosystem functions associated with soil (i.e., nutrient availability) increase, plant species diversity also increases (Cardinale et al. 2012). 
A)

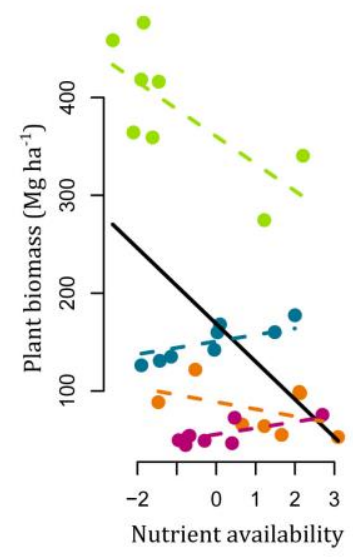

D)

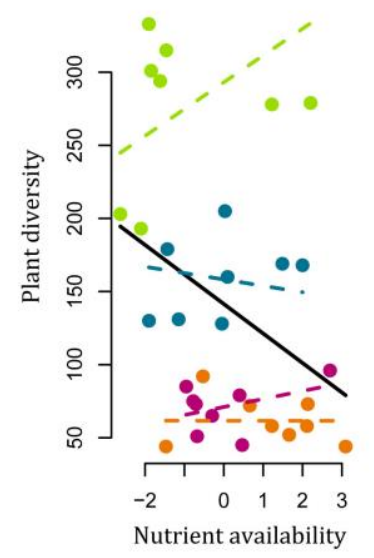

B)

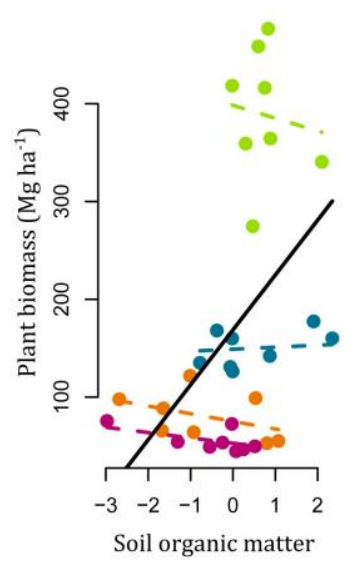

E)

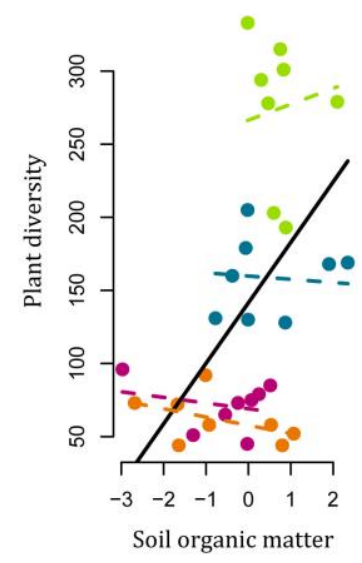

C)

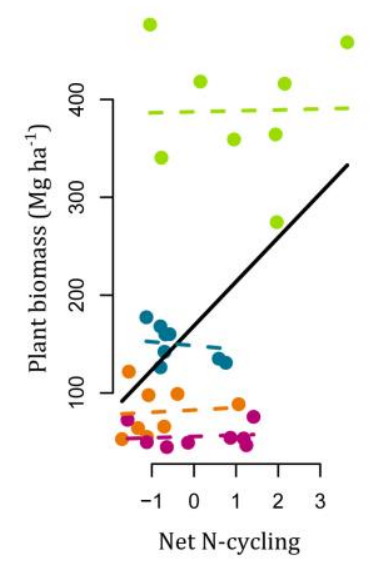

- Forest

- Jungle rubber

- Rubber

- Oil palm

Figure 5.2. Pairwise relationships amongst plant biomass and diversity and the two soil components from the multilevel path model (Fig. 4.2; pg. 81) and the Net $N$ cycling component. The upper row represents relationships between A) Nutrient Availability, B) Soil organic matter and C) Net $N$ cycling and plant biomass. The lower row represents relationships between D) Nutrient availability and E) Soil organic matter and plant diversity. Points are colored according to land-use system; with their respective colored model fits. Model fits for the overall pairwise relationships are shown by a black line.

The significant effects observed between the soil components and microbial communities correspond to an ancillary study conducted at the same study sites during the same study period by Schneider et al. (unpublished data). As Nutrient availability increased archaeal diversity decreased and this overall trend was also apparent across the individual land-use systems ( $\mathrm{P} \leq 0.01$; Fig. 5.3A). Little is known about the Domain Archaea, especially archaeal communities in soil. It is generally accepted that archaea are extremophiles, and are adapted to surviving in inhospitable environments. This could potentially be why we see higher archaeal diversity in our land uses 
with lower soil nutrient availability (Schneider et al. unpublished data). Conversely, as Nutrient availability increased, bacterial diversity also increased and this trend was strongest in the forest and oil palm land uses ( $\mathrm{P} \leq 0.01$; Fig. 5.3B). The cultivation practices associated with soil nutrient availability have been found to influence soil bacterial communities, where a higher more diverse bacterial community can be found in monoculture plantations (rubber and oil palm: Schneider et al. unpublished data; oil palm plantations: Tripathi et al 2012). Both studies observed that increasing soil $\mathrm{pH}$ and nutrient contents present in these agricultural land uses positively affected soil bacterial diversity.
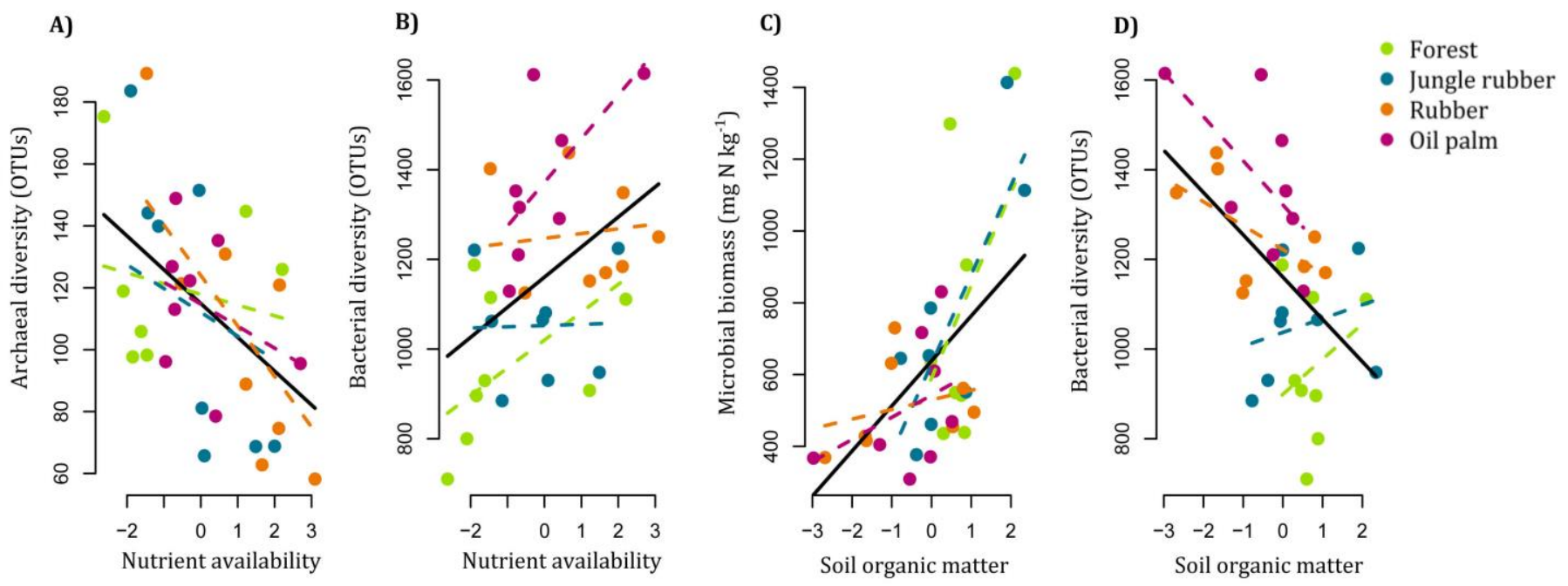

Figure 5.3. Pairwise relationships amongst microbial biomass and diversity and the two soil components from the multilevel path model (Fig. 4.2; pg. 81). The first two figures represent relationships between Nutrient availability and A) archeal diversity and B) bacterial diversity. The second two figures represent relationships between Soil organic matter and D) microbial biomass and E) bacterial diversity. Points are colored according to land-use system; with their respective colored model fits. Model fits for the overall pairwise relationships are shown by a black line.

We also found that soil microbial biomass increased with Soil organic matter $(\mathrm{P} \leq 0.01$; Fig. 5.3C), a trend that was strongest in the forest and jungle rubber land uses. This relationship reflects results from the first study in this thesis, where we found that soil nutrient status and $\mathrm{N}$ availability in our land-use systems were directly hinged on microbial biomass. Therefore, the higher the amount of organic matter in soil, the higher the soil microbial biomass pool and soil nutrient cycling 
rates, which was prevalent within in our reference land uses (i.e., forest and jungle rubber; Table 2.2; pg. 40). The overall decreasing trend in bacterial diversity with increasing Soil organic matter was predominantly driven by the converted land uses. Opposite trends were present across the forest and jungle rubber land uses ( $\mathrm{P} \leq 0.01$; Fig. 5.3C). Although bacterial diversity is higher in the monoculture plantations (Schneider et al. unpublished data; Tripathi et al. 2014), these systems without the influence of biomass burning, fertilization and liming could potentially exhibit a similar trend to the forest and jungle rubber land uses, and show lower bacterial diversity due to the inherently lower soil organic matter storage in these systems (Wagg et al. 2014).

The two soil components created for the multilevel path model (i.e., Nutrient availability and Soil organic matter) appeared to have a greater influence on biotic factors within our systems, compared to the Net $N$ cycling component. In humid tropical lowland systems, $\mathrm{N}$ is often found in relative excess compared to other nutrients and can be cycled in larger quantities compared to temperate systems (Hedin et al. 2009). Thus, $\mathrm{N}$ may not act as a controlling factor on plant and microbial communities in our systems, which may have contributed to the fairly non-existent relationships observed between available $\mathrm{N}$ and these organisms. Although, significant effects between the soil components and biotic variables were observed, a majority of the proportion of variation within these effects was most likely influenced by land-use change. This is attested by the relatively low proportions of variation observed within the soil component models (11-27\%; Nakagawa and Schielzeth 2012). Therefore, modelling the interactive effects between the soil components and land-use change (similar to the path model) could potentially explain a higher proportion of variation within the effects on the biotic variables (Fig. 4.2; pg. 8.1). Nevertheless, of the direct soil component models on the biotic variables, the strongest relationships were found between the soil components and soil microbial communities (all $\mathrm{P} \leq 0.01$; marginal $\mathrm{R}^{2}$ ranged from 0.19-0.27), indicating that these soil properties may aid in explaining a higher proportion of variation within our microbial models. Much of the nutrient cycling and soil organic matter storage in soils is microbially driven, and most likely, the relationships observed between the soil components and microbial biomass and diversity are somewhat cyclic. Because microbial communities mediated higher trophic levels within our multilevel path model, it can be assumed that the soil properties that impact these communities indirectly impact the higher trophic groups. This demonstrates that the effect of soils within the ecosystem may vary, but these effects whether strong or weak play a role in maintaining and structuring the ecosystem. 


\section{References}

Bardgett RD, Cook R. Functional aspects of soil animal diversity in agricultural grasslands. Appl Soil Ecol. 1998; 10: 263-276.

Barnes AD, Jochum M, Mumme S, Haneda NF, Farajallah A, Widarto TH, Brose U. Consequences of tropical land use for multitrophic biodiversity and ecosystem functioning. Nat Commun. 2014; doi: $10.138 /$ ncomms6351.

Cardinale BJ, Duffy JE, Gonzalez A, Hooper DU, Perrings C, Venail P, et al. Biodiversity loss and its impact on humanity. Nature. 2012; 486: 59-67.

Chaplot V, Bouahom B, Valentin C. Soil organic carbon stocks in Laos: spatial variations and controlling factors. Glob Chang Biol. 2010; 16: 1380-1393.

Cohen J. Statistical power analysis. Curr Dir Psychol Sci. 1992; 1: 98-101.

Crawley MJ. The R Book. Chichester, West Sussex: John Wiley \& Sons Ltd; 2007.

Hedin LO, Brookshire ENJ, Menge DNL Barron AR. The nitrogen paradox in tropical forest ecosystems. Annu Rev Ecol Evol Syst. 2009; 40: 613-635.

Hillel D. Introduction to soil physics. London, UK: Academic Press; 1982. pg. 364.

Nakagawa S, Schielzeth H. A general and simple method for obtaining $\mathrm{R}^{2}$ from generalized linear mixed-effects models. Methods Ecol Evol. 2013; 4: 133-142.

Parkin TB. Spatial variability of microbial processes in soil - a review. J Environ Qual. 1993; 22: 409417.

Powers JS, Schlesinger WH. Relationships among soil carbon distributions and biophysical factors at nested spatial scales in rain forests of northeastern Costa Rica. Geoderma. 2002; 109: 165-190.

R Core Team. R: A language and environment for statistical computing. R Foundation for Statistical Computing, Vienna, Austria. Available: http://www.R-project.org/ . Accessed 1 June 2014.

Tripathi BM, Kim M, Singh D, Lee-Cruz L, Lai-Hoe A, Ainuddin AN, Go R, et al. Tropical soil bacterial communities in Malaysia: $\mathrm{pH}$ dominates in the equatorial tropics too. Microb Ecol. 2012; 64: 474484.

Veldkamp E, Purbopuspito J, Corre MD, Brumme R, Murdiyarso D. Land use change effects on trace gas fluxes in the forest margins of Central Sulawesi, Indonesia. J Geophys Res. 2008; doi:10.1029/2007JG000522.

Wagg C, Bender SF, Widmer F, van der Heijden GA. Soil biodiversity and soil community composition determine ecosystem multifunctionality. P Natl Acad Sci USA. 2014; 111: 5266-5270. 


\section{Supplementary material}

To explore relationships between $\mathrm{N}$ cycling processes and the biotic variables from the multilevel path model, a Net $N$ cycling composite variable was created using principal components analysis (PCA; princomp function; R Core Team 2014). Net $N$ cycling is a composite of net $\mathrm{N}$ mineralization rates and net nitrification rates measured at each of the 32 replicate plots using the in-situ buried bag method. Principal component 1 (PC1) from Net $N$ cycling accounted for $84.6 \%$ of the total variation (S5.1 Fig. A) and both net $\mathrm{N}$ mineralization and net nitrification were equally loaded and showed positive relationships with the PC1 scores (S5.1 Fig. B). Thus, the higher the Net $N$ cycling PC1 scores, the higher the rates of net $\mathrm{N}$ mineralization and net nitrification.

A)

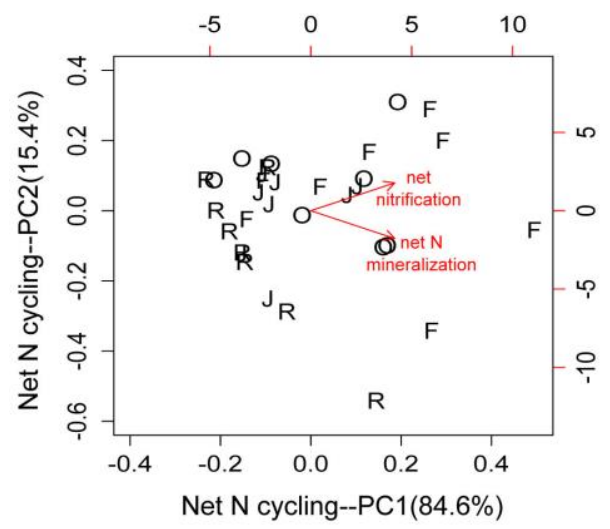

B)

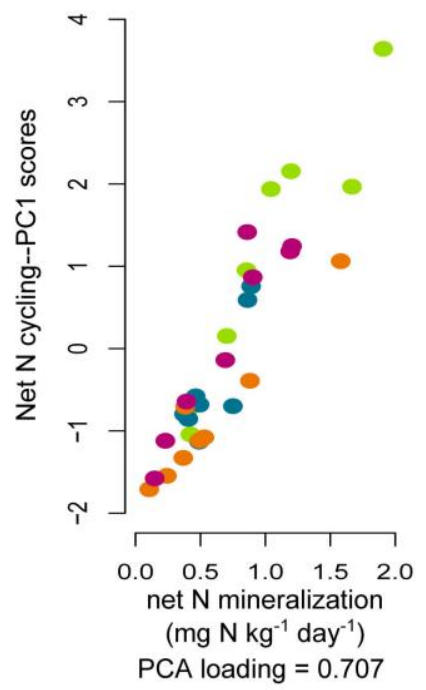

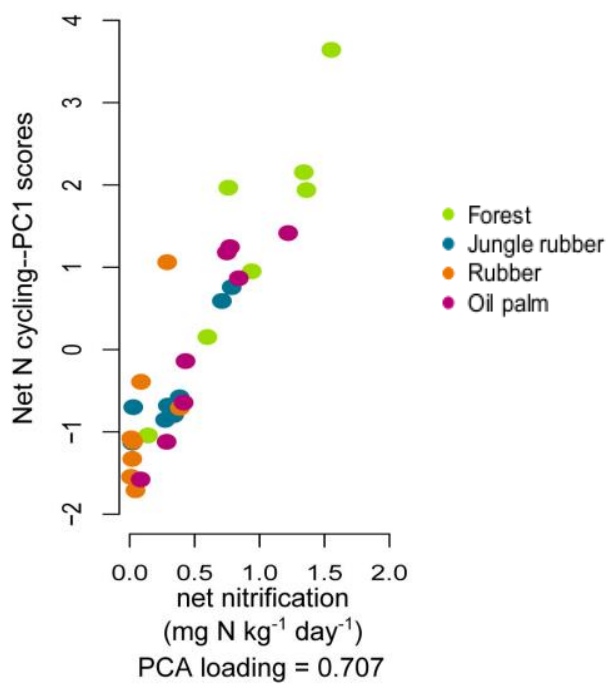

S5.1 Figure A) Principal components analysis (PCA) plot of the Net $N$ cycling composited variable. The eight replicate plots of the four land-use types are plotted along PCA axes 1 and 2 (proportion of explained variance in parentheses) with red vectors (parameters included in PCA composite) illustrating factor loadings. Land-use systems are forest (F), jungle rubber (J), rubber monoculture (R), and oil palm monoculture (0). B) Relationships among the PC1 scores for the Net N cycling composited variable and the parameters incorporated within the Net $N$ cycling composited variable. Data points represent the eight replicate plots of the four land-use types. 


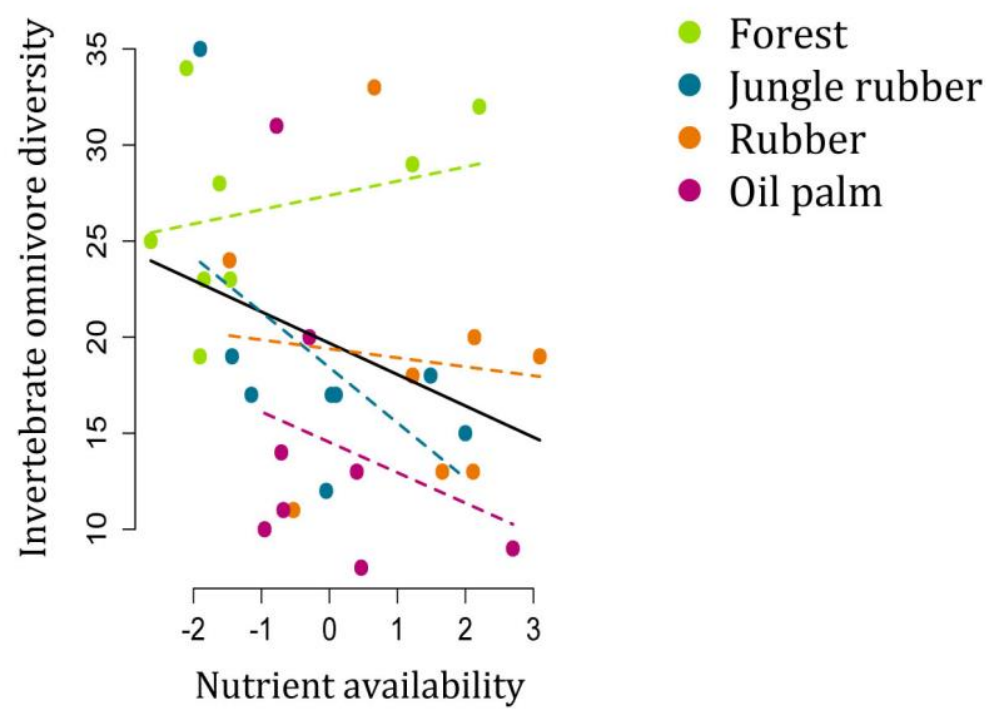

S5.2 Figure. Pairwise relationship between invertebrate omnivore diversity and Nutrient availability component from the multilevel path model (Fig. 4.2; pg. 80). Points are colored according to land-use system; with their respective colored model fits. Model fits for the overall pairwise relationship are shown by a black line.

\section{Reference}

R Core Team. R: A language and environment for statistical computing. R Foundation for Statistical Computing, Vienna, Austria. Available: http://www.R-project.org/ . Accessed 1 June 2014. 


\section{Acknowledgements}

I gratefully acknowledge the financial support for my $\mathrm{PhD}$ research within the CRC 990: EEFForTs project, which was provided by the Deutsche Forschungsgemeinschaft (DFG).

I would like to personally thank my PhD supervisors, Dr. Marife D. Corre and Prof. Dr. Edzo Veldkamp, for providing me with this opportunity as well as supporting me throughout the entire process.

Working in Indonesia would not have been possible without the help and guidance from so many people involved in the CRC 990: EEFForTs project. I am very grateful to the management teams in Germany and Indonesia for helping me to acquire all proper documentation, as well as support me during my research stay in Indonesia. I am also thankful for the help and guidance from my Indonesian Counterparts-Dr. Aiyen Tjoa, Dr. Sri Rahayu Utami and Dr. M. Damris. None of this work could have been completed without the help from my field and laboratory assistants, Fahrurrozy Borland and Khairul Anwar. I would also like to thank and acknowledge the many smallholder farmers, national park rangers, and community members I worked with and stayed with during my time Indonesia.

I would like to especially thank Pak Syahrul Kurniawan, my subproject A05 colleague, for all of the long days spent together in the field as well as stepping-in and taking control of a not-so-pleasant situation without hesitation.

To my “CRC Family," Lisa, Ana, Alex, Andrew, Thomas, Mick, Vijesh, Martin, Malte, Yvonne, Josie, Evelyn, Katja, Marcel, Bernhard, Tom, Stefanie, Siria, Mimi and Anne, I of course thank you for your support, but mostly I thank you for all of the laughs we as a group had during our time in Indonesia. Without our sense of humor, we all know we would have never survived and I am thankful for the crazy moments I was able to spend with each and every one of you!

I would also like to acknowledge my present and past colleagues (Marleen, Oliver, Marcus, Amanda, Armando, Ina, Anke, Yuan, Ian, Suzette, Angelica, Andrea, Kerstin, Martina, Dirk, Myo, and Ruffy) within the PTS Group for their patience during presentations, map creating skills, free apartments on short trips to Germany, R and stats guidance, assistance in the laboratory and overall support throughout my PhD.

Most importantly, I would like to thank my family (Mo, Diddy, Bubby and Gaby) for their inspiration and support. Mom and Dad, when I graduated from high school, you told me that "Twenty years from now you will be more disappointed in the things you didn't do than by the ones you did doMark Twain" and I think it is safe to say that since that time I have very few disappoints and regrets. As I threw off the bowlines some 15 years ago, you nervously waved goodbye to me from the dock. Time and time again, I caught the trade winds in my sails and journeyed deeper and deeper into unchartered waters. If ever my journeys returned me to safe harbor, you were always there to welcome and support me. When I would inevitably set sail again, you never discouraged me, you only wished me caution and luck and again waved goodbye from the dock. For this unconditional support and encouragement, I am eternally grateful. Soon, I will embark on my next journey, I am looking forward to feeling the wind catch my sails and take me into the unknown, and I know that all of this is only possible because of the strong-will and independence you instilled in me.

Thank you, Terima Kasih, Danke. 


\section{DECLARATION OF ORIGINALITY AND CERTIFICATE OF AUTHORSHIP}

I, Kara Allen, hereby declare that I am the sole author of this dissertation entitled "Impacts of land-use conversion in Sumatra, Indonesia on soil nitrogen cycling, soil nutrient stocks and ecosystem dynamics." All references and data sources that were used in the dissertation have been appropriately acknowledged. I furthermore declare that this work has not been submitted elsewhere in any form as part of another dissertation procedure. I certify that the manuscripts presented in chapters 2,3 and 4 have been written by me as first author.

Göttingen, July 2015

(Kara Allen) 
Date of birth: November 15, 1982

Gender: Female

Nationality: American

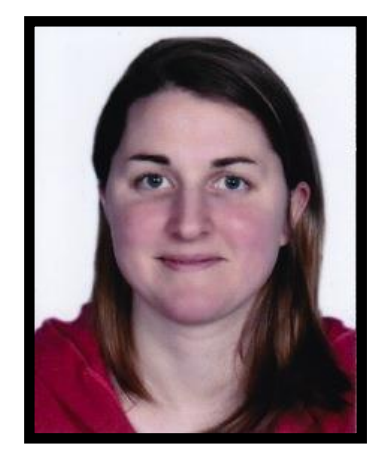

\section{Education}

Georg-August University Göttingen

PhD Candidate

Göttingen, Germany

Soil Science of Tropical and Subtropical Ecosystems Group

April 2012-September 2015

The University of Manchester

MSc in Environmental Science, Policy and Management (MESPOM) with Distinction

Thesis: The Few, The Basic, The Hardy: characterizing fungal communities in high pH environments

Graduated: September 2010

The University of the South

BSc in Environmental Studies: Natural Resources and the Environment

Sewanee, Tennessee

Undergraduate Research: Effects of Microstegium vimineum on soil ecology of the Cumberland Plateau Graduated: May 2005

\section{Research Experience}

PhD Candidate

April 2012-Present

EEFForTs Project • Göttingen, Germany and Jambi, Sumatra, Indonesia

Master's Candidate

MESPOM Program • Manchester, United Kingdom

Research Assistant

The University of the South $\bullet$ Sewanee, Tennessee
September 2008-September 2010

September 2004-April 2005

\section{Publications in Progress}

Allen K, Corre MD, Tjoa A, Veldkamp E (2015) Soil nitrogen cycling responses to conversion of lowland forests to oil palm and rubber plantations in Sumatra, Indonesia. PLoS ONE. 10(7): e0133325. doi:10.1371/journal.pone.0133325.

Allen KE, Corre MD, Kurniawan S, Utami SR, Veldkamp E. Spatial variability surpasses land-use change effects on soil biochemical properties of converted lowland landscapes in Sumatra, Indonesia. In prep.

Allen KE and Barnes AD, et al. Tropical land use imposes direct and cascading impacts on biodiversity from bacteria to birds. Submitted. 